UNIVERSITY OF SÃO PAULO

SÃO CARLOS SCHOOL OF ENGINEERING

DULCE BUCHALA BICCA RODRIGUES

Assessment of water security using conceptual, deterministic and stochastic frameworks

São Carlos

2014 
DULCE BUCHALA BICCA RODRIGUES

\title{
Assessment of water security using conceptual, deterministic and stochastic frameworks
}

\author{
Doctoral thesis presented at São Carlos School \\ of Engineering, University of São Paulo, in \\ partial fulfillment of the requirements for the \\ Degree of Doctor in Science: Hydraulics and \\ Sanitary Engineering
}

Advisor: Prof. Dr. Eduardo Mario Mendiondo

\section{Corrected Version (Versão Corrigida)}

São Carlos 
Rodrigues, Dulce Buchala Bicca

R696a Assessment of water security using conceptual, deterministic and stochastic frameworks / Dulce Buchala Bicca Rodrigues; orientador Eduardo Mario Mendiondo. São Carlos, 2014.

Tese (Doutorado) - Programa de Pós-Graduação e Área de Concentração em Hidráulica e saneamento -- Escola de Engenharia de são Carlos da Universidade de são Paulo, 2014 .

1. Water policy. 2. Water scarcity. 3. Water vulnerability. 4. Hydrological modeling. 5. Environmental Flow Requirement. 6. Uncertainty analysis. 7. Cantareira water supply system. I. Título. 


\section{FOLHA DE JULGAMENTO}

\section{Candidata: Engenheira DULCE BUCHALA BICCA RODRIGUES.}

Título da tese: "Avaliação da segurança hídrica a partir de base conceitual, determinística e estocástica".

Data da defesa: 21/11/2014

\section{Comissão Julgadora:}

Prof. Dr. Eduardo Mario Mendiondo (Orientador) (Escola de Engenharia de São Carlos/EESC)

Prof. Dr. Francisco de Assis de Souza Filho

(Universidade Federal do Ceará/UFU)

Prof. Dr. Martinus Servatius Krol

(University of Twente)

Prof. Dr. Walter Collischonn

(Universidade Federal do Rio Grande do Sul/UFRGS)

Dr. José Antônio Marengo Orsini

(Instituto Nacional de Pesquisas Espaciais/INPE)

\section{Resultado:}
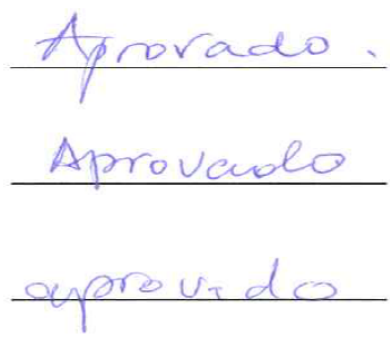

ArROVAD

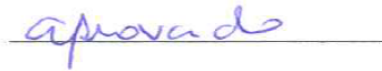

Coordenadora do Programa de Pós-Graduação em Engenharia Hidráulica e Saneamento:

Profa. Associada Maria Bernadete A. Varesche Silva

Presidente da Comissão de Pós-Graduação:

Prof. Associado Paulo César Lima Segantine 


\section{DEDICATION}

To my husband Paulo Tarso, the essential part of me over the past 12 years; to my mother Eliane, my father Antonio Carlos Bicca, and my sister Daniele for everything they did and represent to me; and to my supervisor Prof. Hoshin V. Gupta, for his crucial encouragement during all the time. 


\section{ACKNOWLEDGMENTS}

First, my deepest gratitude to God, the bible's author, who gives me hope and strength day by day. I know is difficult to express my huge gratitude to all friends and colleagues who directly and indirectly supported me during my doctorate period, but I am going to try using few words. I hope I will not forget anyone!

I thank to Professor Eduardo Mario Mendiondo, my advisor, for giving me good opportunities to grow up personally and professionally, including my participation in both Graduate Programs in Brazil and the USA. Then, I thank to Professor Hoshin V. Gupta, my supervisor at The University of Arizona, who gave me the honor to work with and impressive lessons of being a top researcher, collaborator and a mentor.

My very special thank to Danielle A. Bressiani, my lab colleague, that was (and is) an essential friend, with whom I shared life issues, technical discussions, and I could enjoy the advice from the "SWAT Queen"! I am also grateful for all other precious colleagues of my research group (NIBH) at University of São Paulo, who made my workdays much better, and sometimes funnier, such as: Guilherme L. Laurentis, Irene M. C. Pimentel, Jairo Rotava, Gustavo Romero, Aline G. Zaffani, Stephan Birenbaum, Ive Emi Kawatoko, Pedro Caballero, Altair Rosa, Guilherme Samprogna Mohor, Maria Clara Fava, Diego A. G. Arias, and Camilo Restrepo.

I also thank to the colleagues, professors, and technical staff of the Hydrology and Water Resources department (Tucson, USA), for receiving me so amazingly and helping me always so quickly. With whom I enjoyed one of the best period of my life!

Here, in Brazil, my gratitude also refers to the lovely and efficient technical staff of USP Graduate Program (PPG-SHS) (e.g. Sá, Valderes, Flávia, Fernanda, Priscila, André, and Rose), and to number of collaborators from other institutions (e.g. Nilso Fumes, Sabesp; Soraya Voigtel, Terceira Via NGO; Vania Pereira, USP; Eduardo C. Leo, PCJ Water Agency; Gré Lobo, DAEE; Paulo Henrique, Instituto Sócio Ambiental).

Well, I do not have enough words to thank to my husband Paulo Tarso, for being such excellent professional partner, a tremendous blessing in my life, and a patient man during many crazy moments of this doctoral period. Finally, I thank to some very special friends from São Carlos-SP for supporting me and keeping me a sociable person (e.g. Débora, Davi, Débora, Fernando, Talita, Thiago, Maressa, Benvindo, Patrícia, André, Marjolly, Leandro,...) 
and to my family, in particular my mother, my father, and my sister for being with me during all the time, even living $800 \mathrm{~km}$ far away!

The development of this doctoral thesis was feasible due to the specific financial support from São Paulo Research Foundation (FAPESP, grant numbers 2011/11653-0, 2012/05515-6), and CNPq (grant 142592/2010-2). It is also important to mention that the chapters of this doctoral thesis were greatly improved by the English revision of Prof. Hoshin Gupta, and the constructive criticisms from the anonymous journals reviewers. 
"For as the rain comes down, and the snow from heaven, and does not go back again, but gives water to the earth, and makes it fertile, giving seed to the planter, and bread for food; So will my word be which goes out of my mouth: it will not come back to me with nothing done, but it will give effect to my purpose, and do that for which I have sent it" (Isaiah 55: 10-11) 


\begin{abstract}
Rodrigues, D. B. B. (2014). Assessment of water security using conceptual, deterministic and stochastic frameworks. Doctoral Thesis, São Carlos School of Engineering, University of São Paulo, São Carlos.
\end{abstract}

A comprehensive assessment of water security incorporates a range of water-related concepts, since water policy issues to specific technical aspects of hydrological conditions and their interactions with societal needs and ecosystem functioning. This doctoral thesis is organized into three chapters that address such range of water security-related topics, aiming to establish a conceptual baseline and propose deterministic and stochastic accounting frameworks for a river basin water security evaluation. Specific assumptions and research questions are defined in each chapter, and are related to the management of 'Cantareira water supply system' (located in Southeastern Brazil), focusing on different scales and on its political and hydrological aspects as well. The first chapter acts as a conceptual baseline for water security assessment, by examining general aspects of the Brazilian water policy and water allocation system. This study contrasts Brazilian and American water management systems applied to water transfer projects, discussing experiences from the 'Cantareira system' and Colorado river basin. A deterministic accounting framework is presented in the second chapter, which is based on management of blue and green water kinds (defined in accordance with hydrological processes and storage types), and demonstrates how a quantitative analysis of provisioning and use (abstraction and consumption) of both water kinds can be conducted. An agricultural basin $\left(291 \mathrm{~km}^{2}\right)$ within the Cantareira water supply system (located upstream of the Cachoeira reservoir) was used to illustrate this approach. The impact of blue and green water use on median water resources conditions is accounted by the scarcity indicator, while the vulnerability indicator considers the probability of low availability of water resources. In the third chapter quantifies and discusses the impacts of uncertainties on water security indicators (proposed in the chapter 2), based on a multi-model and resampling framework, that considers several uncertainty sources including those related to: i) observed streamflow data; ii) hydrological model structure; iii) residual analysis; iv) Environmental Flow Requirement methods; v) the definition of critical conditions for water provision; and vi) the critical demand imposed by human activities. Then, the uncertainty is propagated through different methodological arrangements applied to the same study basin of chapter 2 . In brief, the first chapter indicates that both Brazilian and American water management system can potentially contribute to each other. In the second chapter, the Blue/Green water-based accounting framework reveal clear spatial and temporal patterns of water scarcity and vulnerability levels within the basin, thereby improving our understanding of how and where water-related threats to human and aquatic ecosystem security can arise (so called hot-spots). The third chapter provide a general method that can form basis for meaningful support to end-users facing water resource challenges by enabling them to incorporate a viable uncertainty analysis into a robust decision making process. Further investigation are proposed in each research step of this doctoral thesis.

Keywords: Water policy, Water scarcity, Water vulnerability, Hydrological modeling, Environmental Flow Requirement, Uncertainty analysis, Cantareira water supply system. 


\section{RESUMO}

Rodrigues, D. B. B. (2014). Avaliação da segurança hídrica a partir de base conceitual, determinística e estocástica. Tese de Doutorado, Escola de Engenharia de São Carlos, Universidade de São Paulo, São Carlos.

A avaliação da segurança hídrica pode incorporar vários conceitos relacionados à água, desde aspectos da política de recursos hídricos até questões hidrológicas específicas e suas interações com a sociedade e ecossistemas. Esta tese de doutorado busca estabelecer uma base conceitual e propor esquemas metodológicos com base determinística e estocástica para avaliação da segurança hídrica de bacias hidrográficas. Objetivos específicos são definidos em cada capítulo e relacionam-se à gestão do 'Sistema Cantareira de abastecimento de água' (localizado no Sudeste do Brasil), com foco em diferentes escalas, bem como aspectos políticos e hidrológicos. O primeiro capítulo é apresentado como baseline conceitual, examinando aspectos gerais da política de recursos hídricos e sistemas alocação de água. Este estudo compara sistemas de gestão aplicados à projetos de transposição de água inter/intrabacias no Brasil e Estados Unidos, discutindo experiências do Sistema Cantareira e da bacia do rio Colorado. O segundo capítulo, por sua vez, propõe e analisa um esquema metodológico determinístico baseado na gestão das águas azul e verde (definidas de acordo com processos hidrológicos e unidades de armazenamento). Este estudo demonstra como uma análise quantitativa da provisão e utilização de ambos os tipos de água pode ser conduzida, propondo indicadores de escassez e vulnerabilidade hídrica. Esta abordagem foi aplicada em uma bacia agrícola $\left(291 \mathrm{~km}^{2}\right)$, localizada a montante do reservatório Cachoeira, que é integrante do Sistema Cantareira. O terceiro capítulo quantifica e analisa os impactos das incertezas sobre os indicadores de segurança hídrica propostos no capítulo 2, utilizando um esquema metodológico estocástico baseado em multiplos modelos e reamostragem, que incorpora variadas fontes de incerteza, tais como: i) dados observados de vazão; ii) estrutura do modelo hidrológico; iii) análise de resíduos do modelo hidrológico; iv) estimativa de vazão ambiental; v) definição de condições críticas de provisão e vi) demanda hídrica. Em seguida, as incertezas são propagadas através de diferentes arranjos metodológicos aplicados na mesma bacia estudo do capítulo 2. Em conclusão, o primeiro capítulo sugere uma potencial troca de contribuições provenientes de ambos os sistemas de gestão brasileiro e americano. $\mathrm{O}$ segundo capítulo revela padrões espaciais e temporais dos resultados dos indicadores de escassez e vulnerabilidade, melhorando assim a compreensão de como e onde ameaças à segurança hídrica podem surgir. Por sua vez, a análise de incertezas desenvolvida no terceiro capítulo é capaz de gerar suporte à gestores de recursos hídricos e processo de tomada de decisões robustas. Recomendações específicas são geradas em cada capítulo da presente tese de doutorado.

Palavras-chave: Política de recursos hídricos, Escassez hídrica, Vulnerabilidade hídrica, Modelagem hidrológica, Vazões ambientais, Análise de incertezas, Sistema Cantareira de abastecimento de água. 


\section{LIST OF FIGURES}

Figure 1.1 - Main elements of brazilian water policy (data source from Brazil, 1997 and Porto, 1998)

Figure 1.2 - Inter-basin water transfer between piracicaba and upper tietê river basins through the cantareira water supply system (data source from Socioambiental Institute ISA, Whately and Cunha, 2007)

Figure 1.3 - Colorado river basin showing the main dams (data source from National Atlas of the United States, 2013).

Figure 1.4 - Water allocation timeline of the colorado river basin (data source from USBR, 2013b)

Figure 2.1 - A blue/green water-based accounting framework for assessment of water security

Figure 2.2 - Study area represented by cachoeira river basin $\left(291 \mathrm{~km}^{2}\right)$, which is divided into two upstream sub-basins ( $a$ and $b$ ) and covered by land use map correspondent to reference year 2010. The locations of water permits and hydrological gages are shown.

Figure 2.3 - Observed and simulated time series at daily time scales during the calibration and evaluation periods

Figure 2.4 - Distribution of water permits for abstractions and wastewater discharge for each water use sector and sub-basin studied.

Figure 2.5 - GW-Scarcity (on the left) and -Vulnerability (on the right) indicators for the cachoeira river basin and each sub-basin studied. On the left it showed graphs with monthly means of rainfall $(\mathrm{mm}), G W$-Footprint $\left(\mathrm{mm} \mathrm{month}{ }^{-1}\right)$, and Provision (mm), where each standard deviation bar was obtained using the time series of each specific month. On the right it presented graphs with the monthly mean of $G W$-Footprint $\left(\mathrm{mm}\right.$ month $\left.^{-1}\right)$, $30^{\text {th }}$ percentile of monthly GW-Provision $(\mathrm{mm})$ and rainfall $(\mathrm{mm})$, where the $G W$-Vulnerability values above 1 correspond to vulnerable conditions. .66

Figure 2.6 - flow duration curves and EFR estimates for each month of the year (above); and median and 30th-percentile of blue water provision considering different EFR methods at the basin studied (bottom left and bottom right, respectively). The standard deviation bars were obtained using the values set of each specific month. Legend: bw-provision- $\mathrm{Q}_{7,10}$ (from low streamflow method); bw-

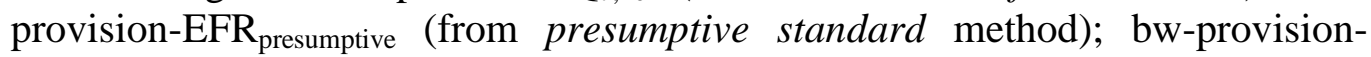
$\mathrm{EFR}_{\text {moderate, }}-\mathrm{EFR}_{\text {fair }}$ (from adapted smakhtin-metodology for emcs referring to moderate and fair conservation goals, respectively); qmean (long-term mean monthly values for streamflow discharge); qmedian (long-term median monthly values for streamflow discharge). 68

Figure 2.7 - bw-scarcity due to current and critical consumptive water use (BW-Footprint), considering different EFR methods at the basin and sub-basins studied. . Legend: $\mathrm{BW}-\mathrm{Scarcity}-\mathrm{q}_{7,10}$ (from low streamflow method); BW-Scarcity-EFR $\mathrm{Bresumptive}$ (from presumptive standard method); BW-Scarcity-EFR $\mathrm{Boderate}_{\text {, }}-\mathrm{EFR}_{\text {fair }}$ (from adapted smakhtin-metodology for emcs referring to moderate and fair conservation goals, respectively).

Figure 2.8 - BW-Vulnerability from current and critical water abstractions, considering different EFR methods at the basin and sub-basins studied. Legend: BW-Vuln.$\mathrm{Q}_{7,10}$ (from low streamflow method); BW-Vuln.-EFR $\mathrm{Bresumptive}_{\text {(from presumptive }}$ 


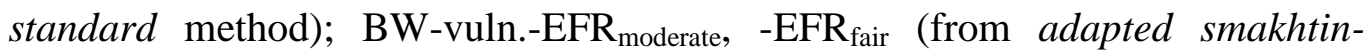
metodology for emcs referring to moderate and fair conservation goals, respectively)

Figure 3.1 - Methodological scheme of the probabilistic multi-model and resampling approach

Figure 3.2 - Study area represented by cachoeira river basin $\left(291 \mathrm{~km}^{2}\right)$, which is covered by land use map correspondent to reference year 2010. The locations of hydrological gages are shown

Figure 3.3 - Statistics for model performance with regards to daily streamflow (above) and scatterplot graphs for the calibration and evaluation periods (below)

Figure 3.4 - The streamflow output values simulated by the swat and hymod models (black) overlayed on the probable error range of the observed data (red)

Figure 3.5 - Uncertainty bounds of observed (red) and simulated (grey) streamflow time series during the calibration and evaluation periods (1987-2001) for a specific methodological arrangement that uses the two-component hydrograph and block bootstrap method (above). Overlapping values, in terms of area and period of time, between both time series ranges and water volume within simulated streamflow range (95\% confidence interval) according to each methodological arrangement analyzed (below)

Figure 3.6 - Confidence intervals of environmental flow requirements in accordance with two hydrological models and different methodological arrangements to estimate the uncertainty boundaries. Legend: $\mathrm{EFR}_{\text {presumptive }}$ (blue), $\mathrm{EFR}_{\text {fair }}$ (pink), $\mathrm{EFR}_{\text {moderate }}$ (green), $\mathrm{Q}_{7,10}$ (grey).

Figure 3.7 - Confidence intervals of water scarcity (above) and vulnerability (below) indicators in accordance with methodological arrangements. Legend: indicator results using $\mathrm{EFR}_{\text {presumptive }}$ (blue color), $\mathrm{EFR}_{\text {fair }}$ (pink), $\mathrm{EFR}_{\text {moderate }}$ (green), $\mathrm{q}_{7,10}$ (grey), average indicator range (yellow). 


\section{LIST OF TABLES}

Table 2.1 - Land use distribution for the cachoeira river basin and sub-basins

Table 2.2 - Input data sources for swat modeling of the cachoeira river basin

Table 2.3 - Streamflow related swat parameter values that were calibrated or changed from their default values

Table 2.4 - Annual average of green and blue water flows, variation of storage and footprint components from aggregation of results for cachoeira river basin at the current LULC

Table 3.1 - Methods for evaluating environmental flow requirements 87

Table 3.2 - Streamflow-related swat parameter values that were calibrated or changed from their default values

Table 3.3 - Parameters of hymod model 90

Table 3.4 - Block lengths used in methodological arrangements involving block bootstrap 96 


\section{TABLE OF CONTENTS}

GENERAL INTRODUCTION

CHAPTER 1: Contrasting Brazilian and American systems for water allocation and transfers: piracicaba and colorado river basin case studies

Abstract

1 Introduction and background

2 Brazilian Aspects

2.1 Development of Water Policy in Brazil: Looking to the Past to Understand the Present 22

2.2 Water Allocation Systems in Brazil and their Application to Water Transfers Projects 23

2.3 Inter/Intra-Basin Water Transfers and Possible Conflicts: Brazilian Case Study 25

3 American Aspects

3.1 Development of Water Policy in the United States: Looking to the Past to Understand the Present

3.2 Water Allocation Systems in the United States and their Application on Water Transfer Projects

3.3 Inter/Intra-Basin Water Transfers and Possible Conflicts: American Case Study

4 Discussion and Conclusions

5 Acknowledgements

6 References

CHAPTER 2: A blue/green water-based accounting framework for assessment of water security

Abstract

\section{Introduction}

2 Materials and Methods

2.1 Study area

2.2 Hydrological Modeling

2.2.1 Model data input and processing

2.2.2 Model calibration and evaluation

2.2.3 Mass balance in SWAT model

2.3 Assessment of Green Water Security

2.4 Assessment of Blue Water Security 
2.4.2 Blue Water provision based on Environmental Flow Requirements (EFR)

2.4.3 Freshwater Provision Indicator

2.4.4 Blue Water Scarcity

2.4.5 Blue Water Vulnerability

3.1 Annual balance of blue and green $\quad 64$

3.2 Temporal and spatial assessment of Green Water Security 65

3.3 Temporal and spatial assessment of Blue water security 67

$\begin{array}{ll}3.4 \text { Potentials and Limitations } & 70\end{array}$

4 Conclusions $\quad 72$

5 Acknowledgements $\quad 74$

$\begin{array}{ll}6 \text { References } & 74\end{array}$

CHAPTER 3: Assessing uncertainties in surface water security: a probabilistic multi$\begin{array}{ll}\text { model resampling approach } & 81\end{array}$

$\begin{array}{ll}\text { Abstract } & 81\end{array}$

1 Introduction $\quad 82$

2 Material and Methods $\quad 84$

2.1 Water Security assessment $\quad 85$

2.2 Hydrological Modeling 87

2.2.1 Soil and Water Assessment Tool (SWAT) model 87

2.2.2 HYMOD model $\quad 89$

2.2.3 Analysis of hydrological models performance $\quad 90$

2.3 Uncertainties in Streamflow Observed data and Hydrological Modeling 91

2.3.1 Estimation of uncertainty boundaries of measured data 91

2.3.2 Estimation of Model Residuals $\quad 92$

2.3.3 Bootstrap of Hydrograph Residuals 93

2.4 Uncertainty propagation through Water Security indicators 94

3 Results and Discussion $\quad 94$

4 Discussion \& Conclusions

$\begin{array}{ll}\text { Appendix A } & 100\end{array}$

5 Acknowledgements $\quad 101$

6 References $\quad 101$

$\begin{array}{ll}\text { GENERAL CONCLUSIONS } & 107\end{array}$ 


\section{GENERAL INTRODUCTION}

Uncertainties regarding future climate, trends in population growth, and changes in lifestyle, are likely to promote opposing trends in water use and water availability, leading to concerns about environmental and human water security risks. It has been estimated that there will, by 2050 , be a 70 percent increase in demand for food production globally (relative to 2009 levels), and up to a 100 percent increase in developing countries (FAO, 2011). Currently, agriculture accounts for 70 percent of global freshwater withdrawals, and more than 90 percent of its consumptive use (FAO, 2012). In the context of Brazil, the National Water Agency predicted that one half of Brazilian cities will experience significant levels of water stress by 2015 (taking into account population growth rates, availability of water resources, and current infrastructure condition of these cities), which would affect approximately 139 million inhabitants (ANA, 2010). Recently, Southeastern Brazil unexpectedly experienced extremely low rainfall during the rainy season, resulting in threats to water security in part of the Metropolitan Region of Sao Paulo city (home to approximately 20 million inhabitants and the most important economic region in Brazil), so that emergency actions were needed to guarantee water supply (The Guardian, 2014). The present decade (2013-2022), entitled "Panta Rhei-Everything Flows" by the IAHS, is focused on the role that hydrological systems play as a changing interface between environment and society, whose dynamics are essential for determining water security, human safety and sustainable development (Montanari et al., 2013).

A comprehensive assessment of water security incorporates a range of water-related concepts, since water policy issues relate to specific technical aspects of hydrological conditions and their interactions with societal needs and ecosystem functioning. This doctoral thesis is organized into three chapters that address such range of water security-related topics, aiming to establish a conceptual baseline and propose deterministic and stochastic accounting frameworks for a river basin water security evaluation.

All specific studies presented in each chapter are related to the management of Cantareira water supply system, focusing on different scales and on its political and hydrological aspects. This system has significant economic and social relevance, because it involves an inter-basin transfer scheme from four dammed tributaries of the Piracicaba (the 
Jaguari, Jacareí, Cachoeira and Atibainha) to the Upper Tietê basin, and is used to supply water to about 9 million people in the Metropolitan Region of Sao Paulo.

The first chapter investigates of general aspects of the Brazilian water policy and water allocation rules applied to water transfer projects, using experiences of the Cantareira system as a case study. This investigation was incorporated into a comparative study related to the American water management system, and its water transfers schemes, for examining potential exchanges between these two water management systems and future perspectives for both countries. By exploring and discussing some fundamental aspects, this chapter acts as a conceptual baseline for water security assessment.

A deterministic accounting framework for evaluation of water security is presented in the second chapter. This study is based on management of blue and green water kinds (defined in accordance with hydrological processes and storage types), and demonstrates how a quantitative analysis of provisioning and use (abstraction and consumption) of both water kinds can be conducted. The impact of Blue and Green water use on median water resources conditions is accounted by the scarcity indicator, while the vulnerability indicator considers the probability of low availability of water resources. An agricultural basin $\left(291 \mathrm{~km}^{2}\right)$ within the Cantareira water supply system (located upstream of the Cachoeira reservoir) was used to illustrate this approach.

Various uncertainties are involved in the representation of processes that characterize interactions between societal needs, ecosystem functioning, and hydrological conditions. In the third chapter addresses some of the uncertainties discussed by the chapter 2 providing a relatively simple approach to verifying the imprecision in water security indicators caused by uncertainties in and among the models/methods used for such estimation. The probabilistic framework based on multi-model and resampling approaches considers several uncertainty sources including those related to: i) observed streamflow data; ii) representation of spatial variability in the hydrological model; iii) residual analysis; iv) the Environmental Flow Requirement; v) the definition of critical conditions for water provision; and vi) the critical demand imposed by human activities. Then, the uncertainty is propagated through different methodological arrangements applied to the same study basin of chapter 2.

Thus, the research steps of this doctoral thesis are integrated to discuss and contribute to some conceptual and accounting aspects of water security assessment. Specific assumptions and research questions are defined in each chapter, which are published or under revision in peer-reviewed international journals. 
It is important to mention that the work presented here, as a whole, was generated from a long and hard process of research and operational activities developed both in Brazil and the United States. Other products were also generated with similar subject, including a book chapter published by Elsevier-Campus (Rodrigues and Mendiondo, 2012), oral presentations in conferences and local seminars in the USA, Argentina, Spain, and Brazil, conference publications (e.g. Rodrigues et al., 2013a, 2013b, 2014), and participation in several research projects. Every step was part of the consolidation process of this doctoral thesis.

\section{Literature Cited}

ANA - Agencia Nacional de Águas (2010). Atlas Brasil: Abastecimento Urbano de Água Panorama Nacional, vol. 1, Engecorps, Brasília.

Food and Agriculture Organization of the United Nations (FAO) (2011). The state of the world's land and water resources for food and agriculture (SOLAW) - Managing systems at risk, Food and Agriculture Organization of the United Nations, Rome and Earthscan, London, U. K. (Available at http://www.fao.org/docrep/017/i1688e/i1688e.pdf.)

Food and Agriculture Organization of the United Nations (FAO) (2012), Coping With Water Scarcity: An Action Framework for Agriculture and Food Security, Rome.

Montanari, A., Young, G., Savenije, H. H. G., Hughes, D., Wagener, T., Ren, L. L. et al. (2013). "Panta Rhei-Everything Flows": Change in hydrology and society-The IAHS Scientific Decade 2013-2022. Hydrological Sciences Journal, 58(6), 1256-1275. doi:10.1080/02626667.2013.809088

Rodrigues, D. B. B., \& Mendiondo, E. M. (2012). Bacias hidrográficas: caracterização e manejo sustentável. In Engenharia Ambiental: Conceitos, Tecnologias e Gestão. São Paulo: Campus-Elsevier, 47-74.

Rodrigues, D. B. B., Mendiondo, E. M., \& Gupta, H. V. (2013a). Water Footprint as a tool for freshwater ecosystem services assessment and water scarcity management. In $A H S$ Symposium "Shifting Boundaries: Recalibrating the Hydrologic Approach". Tucson, AZ: AHS.

Rodrigues, D. B. B., Gupta, H. V., \& Mendiondo, E. M. (2013b). A Blue/Green Water-based Accounting Framework for Assessment of Water Security. In AGU Fall Meeting. San Francisco: American Geophysical Union.

Rodrigues, D. B. B., Gupta, H. V., \& Mendiondo, E. M. (2014). Assessing uncertainties in surface water provision by different bootstrap-based techniques. In EGU General Assembly. Vienna: European Geosciences Union.

The Guardian. (2014). São Paulo faces a critical water shortage as the World Cup prepares to kick off, May 21th 2014. (Available at http://www.theguardian.com/sustainablebusiness/sao-paulo-water-shortage-world-cup) (May 21, 2014). 


\title{
CHAPTER 1
}

\section{CONTRASTING BRAZILIAN AND AMERICAN SYSTEMS FOR WATER ALLOCATION AND TRANSFERS: PIRACICABA AND COLORADO RIVER BASIN CASE STUDIES*}

*A modified version of this chapter has been published as: Rodrigues, D. B. B., Gupta, H. V., Serrat-Capdevila, A., Oliveira, P. T. S., Mendiondo, E. M., Maddock III, T., \& Mahmoud, M. (2014). Contrasting American and Brazilian Systems for Water Allocation and Transfers. Journal of Water Resources Planning and Management, 04014087-1/11. doi:10.1061/(ASCE)WR.1943-5452.0000483. (Journal impact factor: 1.76; Qualis CAPES: A2)

\begin{abstract}
The United States and Brazil both deal with water-related problems associated with being large territorial areas having uneven distribution of water resources and population. Water transfer projects have been widely considered to be feasible solutions to the mitigation of local water shortages. We contrast American and Brazilian water allocation systems and water transfer projects, located in the Colorado and Piracicaba River basins, seeking potential exchanges between these two water management systems and analyzing their adaptability to trends in water demand and climate. Our evaluation indicates that the American system could potentially benefit from some of the principles present in Brazilian framework, including a) participatory approach involving government, users, and citizens, b) recognition of the economic value of water, and c) prioritization of drinking water supply during shortage times. In turn, the Brazilian system could be benefited from certain characteristics of American water management, including reduced bureaucracy and a more efficient decision and operation process. Interestingly, both countries have found it useful to employ soft-path solutions to ensure system adaptability to future water demand and supply.
\end{abstract}

Keywords: Water policy; Surface water management; Water rights; Water shortage 


\section{Introduction and background}

The largest quantities of renewable water resources are concentrated in only a few countries of the world, including Brazil, Russia, Canada, and the United States (Shiklomanov, 2000; Gleick, 2012). However, according to World Bank database (2014a,b,c), populations and water consumption are not distributed in accordance with the availability of water resources. Brazil, for example, has $2.8 \%$ of the world's population but contains $12.8 \%$ of the world's annual renewable fresh water. The U.S., in turn, has $4.5 \%$ of the world's population and $6.7 \%$ of its renewable water resources, but has 5.2 times the per capita water withdrawal and 4.6 times the per capita gross domestic product (GDP) of Brazil. In both countries, their rapidly growing economies and urban populations present major challenges to water infrastructure and allocation. In fact, in many parts of these water-rich territories, water has already become a matter of dispute due to over-population, intensive water use, and periods of scarcity.

In Brazil, approximately $80 \%$ of the available water is concentrated in the Amazon and Tocantins/Araguaia basins, which are inhabited by $6.5 \%$ of the total population. Meanwhile, the remaining $20 \%$ of available surface water supplies the demands of the majority (93.5\%) of the population (Benetti et al., 2004). Three specific regions of Brazil are experiencing significant water problems due to different reasons (ANA, 2010): a) the South requires large amounts of irrigation to grow water-intensive crops (e.g. rice, corn, and soy beans); b) the Southeast has qualitative and quantitative water problems caused by high rates of industrialization and urbanization; and c) the Northeast experiences severe water scarcities due to its semi-arid climate.

The contiguous United States also has significant spatial differences in the distribution of water resources, being commonly divided into the 'Eastern' and 'Western' portions on the basis of climatic conditions (Micklin, 1984). During the latter part of the 19th century, the $100^{\circ}$ meridian west of Greenwich was proposed as the demarcation line for development of different water management strategies for the Eastern (more humid) and Western (more arid/semi-arid) sides (Volkman and Lee, 1988). To the east of this meridian, annual precipitation is significantly higher, making it possible to grow rain-fed crops, which is not possible in most of the West; a major exception being the Pacific Northwest (USDOI, 2013). The southwestern U.S., in particular, has experienced severe water challenges. However, the map has been significantly redrawn by more than a century of reclamation, re-plumbing of 
nearly every river by the use of massive reservoirs, diversions, and the development of irrigation systems (Gleick, 2010). By increasing the supply of water to cities, the percentage of the population now considered "at risk" for water scarcity has been reduced from $47 \%$ (based on the use of only local renewable flows) to less than 17\% (Padowski and Jawitz, 2012).

A major reason for that has been achieved with the development of water supply infrastructure to enable inter-basin water transfers in both the U.S. and Brazil. In the U.S., such inter-basin water transfers have been implemented, chiefly for hydroelectric, municipal, and irrigation purposes (Micklin, 1984), and developments of this kind of infrastructure have expanded the scale of management planning. At large scales, in particular, trans-basin river diversion projects have resulted in considerable controversy and conflict due to losses and damages in the region where water comes from (basin of origin), and conflicts of interest, not to mention project delays and cancellation (Yevjevich, 2001). For example, in 1913, Los Angeles, California, began importing municipal water for urban supply from the Owens Valley, more than $400 \mathrm{~km}$ away. The construction of the Los Angeles Aqueduct generated considerable controversy, and resulted in significant negative impacts for irrigators and the environment in the source basin (Libecap, 2009) with only a few regions remaining relatively unaffected (Elmore et al. 2003). Similarly, in Brazil, the first complex trans-basin river diversion project was completed in 1952, transferring two-thirds of the flow from the Paraiba do Sul River to the Guandu River. Whereas initially designed as a hydropower project to feed the growing city of Rio de Janeiro, it now also supplies water to about 12 million people. Unfortunately, the initial plans did not consider the difficulties of maintaining adequate flow levels during periods of drought, which has resulted in several conflicts between the occupants of the two basins (Andrade et al., 2011).

More recently, and in marked contrast, the development of the São Francisco River project in Northeastern Brazil occurred with considerable public participation over a period of almost 8 years and under stricter environmental laws than those followed in the 1970s (Andrade et al., 2011). Similarly, U.S. diversion projects now require extensive periods of study and considerable planning and design investment, with detailed studies of all aspects of the transfer mechanisms, including environmental and social impacts (Yevjevich, 2001).

Based on accumulated past experience, and reflecting country-specific issues, many countries have revised in recent decades their water resources management policies and laws to introduce new institutional frameworks and management instruments (Veiga and Magrini, 
2013). In this paper, we examine the technical and legal conditions underlying the development of water allocation systems and important water transfer projects in Southeastern Brazil and the Western U.S, with a view to identifying similarities and differences between these two water management systems, and to analyze and understand the relative adaptability of each system to the current trends in demand and climate.

\section{Brazilian Aspects}

\subsection{Development of Water Policy in Brazil: Looking to the Past to Understand the}

\section{Present}

In Brazil, the legal treatment of water can be considered in terms of three distinct historical periods: the Navigability Phase, the Hydroelectricity Phase, and the Environmental Phase. During the first period, water regulation was mainly concerned with navigability and the principal criterion for river regulation was the ability to float cargo downstream, following the Civil Code of 1916. The second period began with the enactment of the Water Code of 1934, which was concerned with the provision of hydroelectric power, multiple uses, and expansion of the domain of public waters. However, the Water Code did not entirely abandon the category of private waters, instituting the classification system of public, common, and private waters (Benjamin et al., 2005). During the third period, enactment of the Brazilian Constitution in 1988 removed all private rights over water resources, thereby characterizing all waters to be public goods belonging either to the Union or to the States, in accordance with river basin boundaries (Veiga and Magrini, 2013).

The 1980s and 1990s were also marked by the publication of important environmental laws, including the National Environmental Policy Act (Law n.6938) of 1981, and the National Water Policy Act (Law n.9433) of 1997. This water law, inspired by the French model, introduced important changes in the administrative, legal and institutional aspects of water resources (Veiga and Magrini, 2013). In this approach, the essential principles include a system of water management by hydrographic basin, river basin committees, independent financing of water policy, and planning instruments for catchment areas (France, 1992; FAO, 1995). Note that the European Water Framework Directive of 2000 has adopted similar principles (Nion, 2009). 
Overall, the Brazilian system of water management might be called a 'Systemic Participatory Integration Model' (Carvalho and Magrini, 2006), and is designed to ensure active participation by a range of stakeholders within each management area, and an emphasis on the economic value of water resources (Ioris, 2009). Since 1997, many states have formulated water laws that meet the federally imposed requirements, and which specify the design and implementation of formal institutions and processes (Engle et al., 2011). The principles, instruments and institutions of Brazilian Water Policy are presented in Figure 1.1.

\begin{tabular}{|c|c|c|}
\hline Principles & Instruments & Institutions \\
\hline $\begin{array}{l}\text { i. Water is a public good } \\
\text { ii. Water is a finite resource and } \\
\text { has an economic value } \\
\text { iii. When scarce, drinking water } \\
\text { supply is the uppermost priority } \\
\text { iv. Management must encompass } \\
\text { multiple uses } \\
\text { v. The watershed is the territorial } \\
\text { unit for management purposes } \\
\text { vi. Water management shall be } \\
\text { based on a participatory } \\
\text { approach involving government, } \\
\text { users and citizens }\end{array}$ & $\begin{array}{l}\text { i. Water resources master plans } \\
\text { ii. } \text { Classification of water bodies } \\
\text { into different categories of use, } \\
\text { related to stream and ambient } \\
\text { water quality standards } \\
\text { iii. A permit system for withdrawals } \\
\text { iv. } \text { Charging for bulk water } \\
\text { v. A water resources information } \\
\text { system }\end{array}$ & $\begin{array}{l}\text { i. The National Council on Water } \\
\text { Resources } \\
\text { ii. The State Councils on Water } \\
\text { Resources } \\
\text { iii. The River Basin Committees } \\
\text { iv. Agencies at the federal, state } \\
\text { and municipal levels with areas } \\
\text { of competence related to the } \\
\text { management of water resources } \\
\text { v. The Water Agencies, the } \\
\text { executive branch of the river } \\
\text { basin committees }\end{array}$ \\
\hline
\end{tabular}

Figure 1.1 - Main elements of Brazilian Water Policy (data source from Brazil, 1997 and Porto, 1998)

The basin committees are comprised of stakeholders representing the Federal, State, and Municipal Governments, well water users, and civil entities functioning in the watershed; the composition can vary from one state to another (Porto, 1998). These committees are in charge of organizing discussions of problems related to the river basin, arbitrating disputes, approving the basin plans, and establishing the fee mechanisms and the amounts to be charged (Carvalho and Magrini, 2006). The moneys collected are used by the Water Agency, and invested in actions planned via the River Basin Water Plans approved by the respective Committee (Braga et al., 2009).

\subsection{Water Allocation Systems in Brazil and their Application to Water Transfers}

\section{Projects}

Brazil divides ownership over water resources between the union and its federal states (Smith, 2009). A river running through more than one State is subject to Federal jurisdiction, meaning that related Concessions and Fees are handled by the Federal Government, whereas if the river origin and mouth lie within the same State, its Concessions and Fees are handled 
by the State Government (Carvalho and Magrini, 2006). Water rights for the use of federal waters are allocated by the National Water Agency, while responsibility for state waters rests with the State. Consumptive surface water and groundwater uses are subject to permitting, as is the discharge of treated or untreated sewage into a body of water for dilution, transport, or disposal. Water rights applications are analyzed for efficiency and reasonable use, and are allocated for a specific period and prescribed terms of agreement, based on the class of use to which the body of water has been assigned.

In several Brazilian states, water rights are released only after considering the conservation requirements to maintain minimum flow in the rivers (Benetti et al., 2004). For example, in the state of Sao Paulo and the Piracicaba, Capivari, and Jundiaí (PCJ) contiguous river basins, the 7-day 10-year low-flow value $\left(\mathrm{Q}_{7,10}\right)$ is used as the reference. This State also takes into account the critical basin water demand, which is established when the sum of water abstractions is greater than $50 \%$ (fifty per cent) of the current reference streamflow (i.e., $\mathrm{Q}_{7,10}$ ); when this limit is reached, a special management plan, that takes into consideration rigorous quantity and quality monitoring, water saving programs and negotiation between the users is required to be developed for the watershed (Sao Paulo State, 1994; PCJ, 2011)

In addition, Brazilian water law (n.9433/1997) contains a kind of American-like "abandonment rule", under which water rights may be partially or entirely suspended, temporarily or permanently, if $i$ ) there is a failure to comply with the terms of the agreement, ii) there is a lack of use for three consecutive years, or it can occur if there is a need to provide for priority uses in the interest of the community. Basin committees are empowered to define both what is meant by insignificant water withdrawals and sewer releases (not subject to permits), and high-priority water uses, taking into account the maintenance of multiple uses in the watershed (one of the principles of water policy).

Note that priority allocation of the funds collected is to the river basin in which they are generated. In 2005, the PCJ basins established charges (average exchange rate of 1 USD = $1.85 \mathrm{BRL}$ ) as follows: 5 USD per 1,000 cubic meters of water extracted, 10 USD per 1,000 cubic meters of water consumed, 50 USD per ton of Biochemical Oxygen Demand (BOD) for sewage dilution into the rivers, and 7.50 USD per 1,000 cubic meters transferred to another basin (GWP 2009). The basic structure of the charging mechanisms is discussed in Braga et al. (2009) and ANA (2009). Currently, the PCJ Committee raises 20 million USD per year (PCJ, 2011), and most of this amount (59\%) is typically allocated to construction of sewage treatment stations and waste disposal (Andrade et al., 2011). However, Brazilian law makes no provision for cases where water is transferred from one basin to another and consequently, 
no management practices are stipulated for this situation, which tends to generate conflicts of interest among users; such as the agreement between PCJ and Upper Tietê basins for Cantareira water supply system- see below (Carvalho and Magrini, 2006).

\subsection{Inter/Intra-Basin Water Transfers and Possible Conflicts: Brazilian Case Study}

The Metropolitan Region of São Paulo (MRSP), located in Sao Paulo State, is the largest urban concentration and industrial complex in Latin America (Braga et al., 2006), consisting of 39 municipalities in an intense process of conurbation, responsible for $19 \%$ of Brazilian GDP, and home to around 20 million inhabitants; $10 \%$ of the national population (Haddad and Teixeira, 2013). Due to disorderly growth of the MRSP, beginning mainly in the 1950 s, the water supply system in the region is quite inadequate, resulting in periodic lack of sufficient water (Braga et al., 2006).

To mitigate this, the 'Cantareira System' inter-basin transfer scheme was initiated in 1966, to transfer waters from four dammed tributaries of the Piracicaba (the Jaguari, Jacareí, Cachoeira and Atibainha), to the Upper Tietê basin (Braga et al., 2001) (Figure 1.2). This project brings water by gravity to the Paiva Castro reservoir, from where it is pumped $120 \mathrm{~m}$ uphill to a treatment station (Braga, 2000). The Cantareira system represents a large fraction (69.2\%) of water availability in the source basin (Andrade et al., 2011). The project was completed in 1973, and now supplies approximately $33 \mathrm{~m}^{3} / \mathrm{s}$, corresponding to about $60 \%$ of all of the water consumed in the MRSP (Braga et al., 2006). 


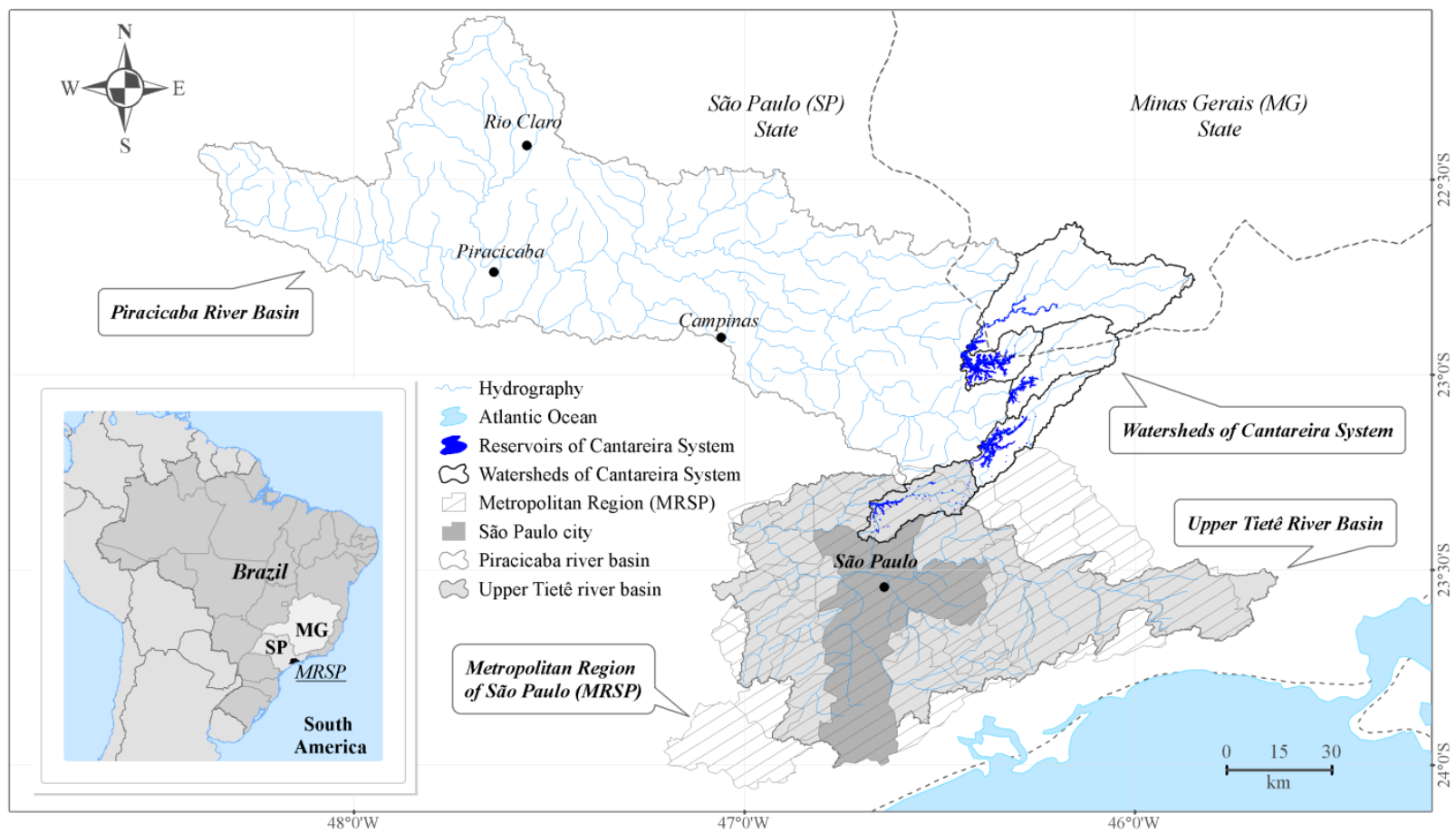

Figure 1.2 - Inter-basin water transfer between Piracicaba and Upper Tietê River Basins through the Cantareira water supply system (data source from Socioambiental Institute - ISA, Whately and Cunha, 2007)

Because it was unusual, in the 1960s, for the population to participate in decisionmaking processes concerning water resources (Braga, 2001), no compensatory measures were established for riparian users when the Sistema Cantareira was designed (Andrade et al., 2011). However, an industrial sector boom in the Piracicaba Basin during the 1980s resulted in heavy industrial and residential development, while also agriculture became highly mechanized (Porto, 1998). This gave rise to enormous industrial and urban development over the following two decades, and generated fierce debate and major conflicts regarding water use, particularly among the users of the Upper Tietê River (Andrade et al., 2011).

Today, having established numerous environmental laws and regulations, the processes for approval of such projects has become much more complex (Andrade et al., 2011). In 2004, the renewal of authorization to transfer water to the MRSP was carried out under a new arrangement (Braga et al., 2006), in which the PCJ Committee river basin management committee played an active role in defining better goals during the licensing renewal process needed to continue water transfers to the Piracicaba River basin. After intense negotiation with the SABESP regional water supply company that operates the water transfers (Andrade et al., 2011), maximum and minimum renewal rates of 24.8 to $31 \mathrm{~m}^{3} / \mathrm{s}$ were defined for the MRSP and 3 to $5 \mathrm{~m}^{3} / \mathrm{s}$ for the PCJ basins, along with operational rules to be applied during drought conditions (PCJ, 2011). During the renewal process, a Water Bank 
mechanism was approved, by which unused water rights during the wet season could be stored and used during dry periods (ANA, 2009).

The negotiation process was supported and supervised by the National Water Agency and the Department of Water and Power of the State of São Paulo and IGAM (water entity of Minas Gerais State) under the express requirement that water should be provided to the Piracicaba River basin to meet their basic demands (Braga et al., 2006). Compensatory measures in the PCJ basins were instituted using financial resources from fees collected from water users. In 2008, the total amounts collected from recipients of Cantareira water transfers were $\sim \mathrm{R} \$ 10$ million (reais) (Andrade et al., 2011). Overall, the authorization renewal and management water transfer process was considered a successful experience for water users in both river basins (Andrade et al., 2011).

The PCJ basins plan now classifies the headwaters of Cantareira system for "Protection and Control" (PCJ, 2011), and the water quality goals within this region refer to the "class 1" for Cachoeira, Atibainha and Jacareí River basins and "class 2" for Jaguari River basin, in accordance with Brazilian CONAMA Resolution no. 357/2005 (Brazil, 2005), which specifies the quality requirement for drinking water and other specific uses (PCJ, 2011). In addition, some economical trade-offs have been made at the Cantareira drainage basins in regards to water supply for downstream water quality protection. These are termed payments for ecosystem services, and are represented by a number of projects, such as "Water Conserver" and "Water Producer", which facilitate financial compensation to rural landowners who preserve and restore forests and grasslands along streams, and who implement best management practices on cropland and cattle ranches (TNC, 2010; 2012).

Recently, the unexpected low amounts of rainfall during the Brazilian rainy season, which are the lowest records ever measured since 1930, promoted an abrupt decrease of the water delivery capacity of the Cantareira System. Consequently this has caused a high scarcity risk for MRSP and the source basin population. Emergency actions were taken to guarantee supply, such as part-time water rationing, financial bonus or penalties according to consumption changes, and water pumping from the bottom of reservoirs ("dead volume") see The Guardian, 21 May 2014. At this critical time, a water transfer project has been proposed to bring water from the neighboring basin (Paraiba do Sul River Basin). This basin supplies the second Brazilian largest city of 'Rio de Janeiro', but negotiations have been difficult among authorities. Under the pressure of being the host of the world's biggest soccer event (2014 World Cup), the 2016 Olympic Games, and amidst this water crisis situation, 
Brazil has put to proof the efficiency of water management system amidst many technical and political discussions.

A few years ago, the National Water Agency analyzed the availability of all Brazilian water resources, growth of the population, and the infrastructure condition, and estimated that Brazil will need to invest a total of R $\$ 22$ billion by 2015 to avoid the possibility that $55 \%$ of the municipalities in the country (including large cities such as São Paulo, Rio de Janeiro, Salvador, Belo Horizonte, Porto Alegre, and Brasília) will suffer from water supply problems (ANA, 2010).

Clearly, Brazil needs to reduce its dependency on a few water sources (e.g. Cantareira system) and increase the resilience capacity for drought conditions. Braga et al. (2006) commented that it would be very difficult to expand the water supply system in the MRSP, because further water transfers from neighboring basins would impose large political and social costs. However, it has become a problematic issue because Upper Tietê Basin, that integrates MRSP, is highly dependent on surface water source, being attributed of low groundwater per capita availability $\left(93 \mathrm{~L}\right.$ inhab.day ${ }^{-1}$ ), where only $0.8 \%$ of the population basin is supplied by groundwater (Hirata et al., 2007). On the contrary, the west of São Paulo State has a larger groundwater per capita availability and shares water from Guarani aquifer and other aquifers (Hirata et al., 2007). Water infra-structure, maintenance and efficiency projects should be implemented, such as decrease of water losses in distribution networks, and pollution control, in addition to widespread non-structural measures (e.g. saving, and reuse) will be also essential.

\section{American Aspects}

\subsection{Development of Water Policy in the United States: Looking to the Past to}

\section{Understand the Present}

In the mid to late 18th Century, developers of American governance and US Constitution were heavily influenced by 'The Enlightenment Age', wherein science and political philosophy were combined so that the construction of government was perceived as an experiment (Ferris, 2010; Doyle, 2012). In this approach, experiments are often used as "pilots" in order to sell new policies and have the capacity to change as needed to reflect changes in the priorities of society (Huitema, 2009; Doyle, 2012). Today, U.S. water management has evolved into a complex legal and administrative framework, built up over 
two centuries and based on the U.S. Constitution, federal and state legislation, judicial decisions, common law, and even international treaties (Christian-Smith and Allen, 2012). Among the numerous pieces of water-related legislation that compose American water policy, particularly important are the following: Rivers and Harbors (1899); Reclamation act (1902); Flood Control act (1917); Federal Power act (1920); Wild and Scenic Rivers Act (1968); National Water Commission Act (1968); National Environmental Policy Act (1969); Water Resources Development Acts (1970s; 2013); Endangered Species Act (1973); and the Clean water Act (1977). While, during the twentieth century, the States initially held considerable discretion in water management, federal authority over water has expanded greatly over time, now encompassing navigation, irrigated agriculture, flood control, hydropower, water quality, and public health concerns (Gerlak 2006).

In 1965, the Federal Water Resources Planning Act provided for the establishment of the Water Resources Council, river basin commissions, and financial assistance to the States water planning programs. The Council was directed to develop principles and standards for basin plans, in addition to criteria for economic evaluation of water resource projects (Curran and King, 1974; Galloway Jr., 2011). Following this, through the National Water Commission Act of 1968, the US recognized the need to give consideration to, among other things, conservation and more efficient use of existing supplies, increased usability by reduction of pollution, innovations to encourage the highest economic use of water, inter-basin transfers, and technological advances (Christian-Smith et al., 2012). Subsequently, the National Environmental Policy Act of 1969, which has been called a revolutionary piece of environmental legislation, established a national policy for the environment, set up the Council on Environmental Quality, and required federal agencies to take environmental impacts into consideration during planning and development (Curran and King, 1974; Cardwell et al., 2006).

Consequently, regulatory policy became the hallmark of environmental legislation during the 1970s (Gerlak 2006). The Endangered Species Act of 1973 (ESA) provided for the conservation of threatened species, and the conservation of the ecosystems upon which they depend. The Clean Water Act of 1977 addressed the control of surface-water pollution through specific tools and water quality standards, and the Safe Drinking Water Act of 1974 established standards for drinking water quality. Since 1974, various Water Resource Development Acts (WRDAs) have been released, which provide for regular authorization by 
the Congress in regards to water resources development projects considered critical for the nation, and implemented by the US Army Corps of Engineers (NRC 1999a).

During the 1970s, the U.S. Water Resources Council designated 21 major waterresources regions and 222 sub-regions as the basis for comprehensive planning, and thereafter the U.S. Geological Survey divided the country into 352 hydrologic accounting units and 2,149 cataloging units (based on surface features) for the management of national water data. Meanwhile, the socio-political scales of cities, counties, and states, are used for the collection and collation of the social and economic data for the U.S. Census (Seaber et al., 1987). Put together, this implements a multi-scale approach to water management (Doyle, 2012). As an example, in response to problems associated with severe groundwater overdraft, the Arizona legislature passed the landmark Groundwater Management Act in 1980, establishing several Active Management Areas, generally based on groundwater basin boundaries (ADWR, 2013).

Overall, the U.S. multi-institutional arrangement is characterized by: $i$ ) federalism, the devolution of responsibilities between national, state, and other local governments (e.g. municipalities, counties); and ii) adaptive management practices via agency structures that are highly malleable and that can change direction (Doyle, 2012). Arguably, however, the nation's strategy for managing water resources is badly fragmented (Christian-Smith and Allen, 2012). While the federal Environmental Protection Agency (EPA) has primary authority over water pollution, the states regulate the allocation of water from lakes, streams, and groundwater, while local governments are generally responsible for regulating the land use practices that are actually responsible for degrading the water quality (Andreen and Jones, 2008). In essence, this amounts to a bifurcated water policy system, where the federal government dominates in regards to quality issues, while the states dictate quantity issues (Gerlak, 2006).

\subsection{Water Allocation Systems in the United States and their Application on Water}

\section{Transfer Projects}

In general, water allocation systems aim to achieve fair water distribution among multiple users, support development priorities, guarantee expected supply, promote efficient water use, and protect the aquatic ecosystem (Speed et al., 2013). Each country, region, or local community tends to develop its own sets of institutions and practices governing the allocation of water, and these continue to evolve as conditions change (Wurbs, 2013). 
In the U.S., surface waters are treated as "a public resource, held in trust for use by the people of the state" (Smith, 2009), but this basic principle has been applied in two different ways - through the riparian and prior appropriation systems. Each State has adopted water codes that outline the details of each system and specify the process by which permits to use water may be obtained (Schutz 2012). Custom, culture, geography, legislation, and case law help shape the way in which each State applies these basic principles (Blaney, 2007). However, a separate system of laws and customs guides the allocation of groundwater resources (Wurbs, 2013).

The American water allocation regime arose from pre-industrial English common law and began with the riparianism system. When the colonists began a new society in eastern U.S. they found a similar physical geography (mixed temperate forest, humid climate, many streams and rivers), and start to apply the same type of water law they were accustomed to back in England (Thompson, 1999).

Riparian rights, in their pure form, allowed owners of land adjoining a watercourse to use/divert water under the natural flow theory, in which every user is obliged to maintain the quantity and quality of the water before and after use. Then this doctrine was modified including theory of reasonable use, changing the condition where riparian user could not hurt the stream (natural flow theory) to the user that should not hurt other riparian users (theory of reasonable use) (Thompson, 1999). The definition of reasonable use is normally agreed upon by riparian neighbors, but in case of conflict between them, it is up to the court to decide on a case-by-case basis (Hu and Eheart, 2014). The riparian doctrine requires users to continually adjust (reduce) their right as new users and uses come along, in other words, the this principle does not protect established users from users that come along later (Thompson, 1999). When drought occurs the shortage is fairly shared by all users (Hu and Eheart, 2014).

Today, riparian-based water systems are mostly recognized only in the eastern half of the U.S. (Smith, 2009). As the United States expanded into the semi-arid Western Territories, a different "prior appropriation" water regime evolved in response to the dry conditions (Cassuto and Sampaio, 2011). Under this doctrine, dominant in the western half of the United States, "the first person to use water acquires the right to its future use as against later takers", which means "first in time first in right" (Smith, 2009). The Western water law was initially developed from experiences, customs, and usage within the early mining camps (Schutz, 2012). As settlers moved from the Eastern states to the West in the 1800 's, people needed 
protection from having their water supplies diminished by later population growth and economic development (Wurbs, 2013).

Under prior appropriation, the water rights to beneficial use are represented by a specific volume per year, and not by a specific proportion of the annual flow. Therefore, in times of low flow, water deliveries to the most "junior" water rights holders are cut off sequentially to ensure water deliveries to "senior" water rights holders (Bark and Jacobs, 2009). The requirement of application for beneficial use is satisfied by irrigation, mining, industrial application, stock watering, domestic and municipal use, and many other nonwasteful economic activities, and has expanded in recent years by some States to include ecological purposes (Blaney, 2007). In other words, leaving water in the stream for recreation and wildlife is now deemed a beneficial use (Burchi, 2012) supported by ESA law (1973) for protection of aquatic habitats.

The rule "use it or lose it" is also part of the appropriative rights concept. Abandonment is established through proof of non-use coupled with 'intent to abandon the water' (Shultz, 2012). This rule is intended to encourage reasonable water use and discourage speculation; unfortunately however, water rights holders commonly use water even when it is not necessary, simply to ensure that they do not lose it through abandonment.

Some hybrid situations do exist in which rules are modified under the two-water rights regimes (e.g., California, Nebraska, and Oklahoma) which allow, under some circumstances, riparian landowners to assert new uses that are "superior" to those with appropriative rights (Davis, 2007; Christian-Smith et al., 2012). Today, about half of the states that were once committed to traditional riparian rights have now enacted a "regulated riparianism" (Dellapenna, 2011), in response to a rapid socioeconomic development, increasing stream protection legislation, and an uncertain climate future (Hu and Eheart, 2014). The regulated system treats water as a public property to be managed by a state agency; thereby no water can be withdrawn from natural sources without a permit (An and Eheart, 2006), combining the flexibility of common law riparianism (by accommodating as many reasonable uses as possible) with the stability of prior appropriation (by allocating a specific quantity of water for the duration of a permit) (Klein et al., 2009). The temporal priority (first in time, first in right) in the permit process is still the main difference between of the riparian-based laws and appropriative rights (Dellapenna, 2011).

In addition to the common methods of allocating water, there are also predefined rights, for example the "Federally reserved rights", for meeting the purposes for which federal lands and Native American reservations were originally set aside (Christian-Smith et al., 
2012). Some western states (e.g. Montana, Idaho, Washington, New Mexico, Colorado, Oregon, Utah, Wyoming, and Nevada) have adopted a strategy of conjunctive water management to deal with the interconnectedness of surface and groundwater (Hazard and Shively, 2011). A more sophisticated technical understanding of the physical link between groundwater and surface water has led some water managers to recognize the inappropriateness of separate water allocation laws (Valdes and Maddock, 2010), finding workable ways to preserve groundwater development while minimizing impacts on flowing streams (Pearce, 2003).

\subsection{Inter/Intra-Basin Water Transfers and Possible Conflicts: American Case Study}

Over the past several decades, rapid population growth in the Western U.S. has forced municipalities to secure new water supplies (WGA and WSWC 2012). In particular, interbasin water transfers from water-abundant regions (donors) have been adopted as a solution to securing water supply to support development in regions with water shortages (recipients) (Gohari et al., 2013). A large number of connections between natural and artificial water routes have been delineated in the Western U.S. (Foti et al., 2012). During the 20th century, resource management at all levels has reflected the prevailing management philosophy of the time: to build large-scale, centralized, federally subsidized infrastructure for moving water in both space and time to meet current and projected demands (Gleick, 2010).

In particular, water projects along the Colorado River have shaped the face of the southwestern region, enabling agricultural development in semiarid lands by use of irrigation systems (Gleick, 2010), and encouraging the growth of major metropolitan areas such as Albuquerque, Denver, Las Vegas, Los Angeles, Phoenix, Salt Lake City, and San Diego (Robison and Kenney, 2012). Between 1920 and 2000, population growth in the seven states that share the Colorado River grew 762\% (Gleick, 2010), and the basin currently provides water to nearly 40 million people for municipal use while supplying nearly 5.5 million acres of irrigated land, and at least 22 federally recognized tribes (USBR, 2013). Substantial amounts of water from the Colorado River are used to grow food (Gleick 2010), with approximately $80 \%$ of the total water withdrawal being consumed by agriculture and the remaining 20\% used for municipal and industrial purposes (USBR, 2013).

Since the 1930s, significant infrastructure has been constructed on the system, including the two largest reservoirs in the United States (Lake Mead and Lake Powell) such 
that total storage in the Colorado River Basin now exceeds four times the annual flow (Grafton et al., 2013). In addition, several water diversions have been constructed, including aqueducts, tunnels, pipelines, and canals for agricultural, municipal, and industrial uses. The major inter/intra-basin water transfers from the Colorado River are: the Colorado River Aqueduct (to the city of Los Angeles-CA); Central Arizona Project (to central Arizona, including Phoenix and Tucson); Coachella Canal and All American Canal (to Southern California), Alamo Canal and Tijuana-Colorado River Aqueduct (to Baja California, Mexico); Mode Canal (to Sonora, Mexico); Wellston-Mohawk Canal (to Southern Arizona); Government Highline Canal (to Western Colorado); and the Adams Tunnel, part of ColoradoBig Thompson Project (to Eastern Colorado) (USBR 2013a; NatGeo, 2013) (Figure 1.3).

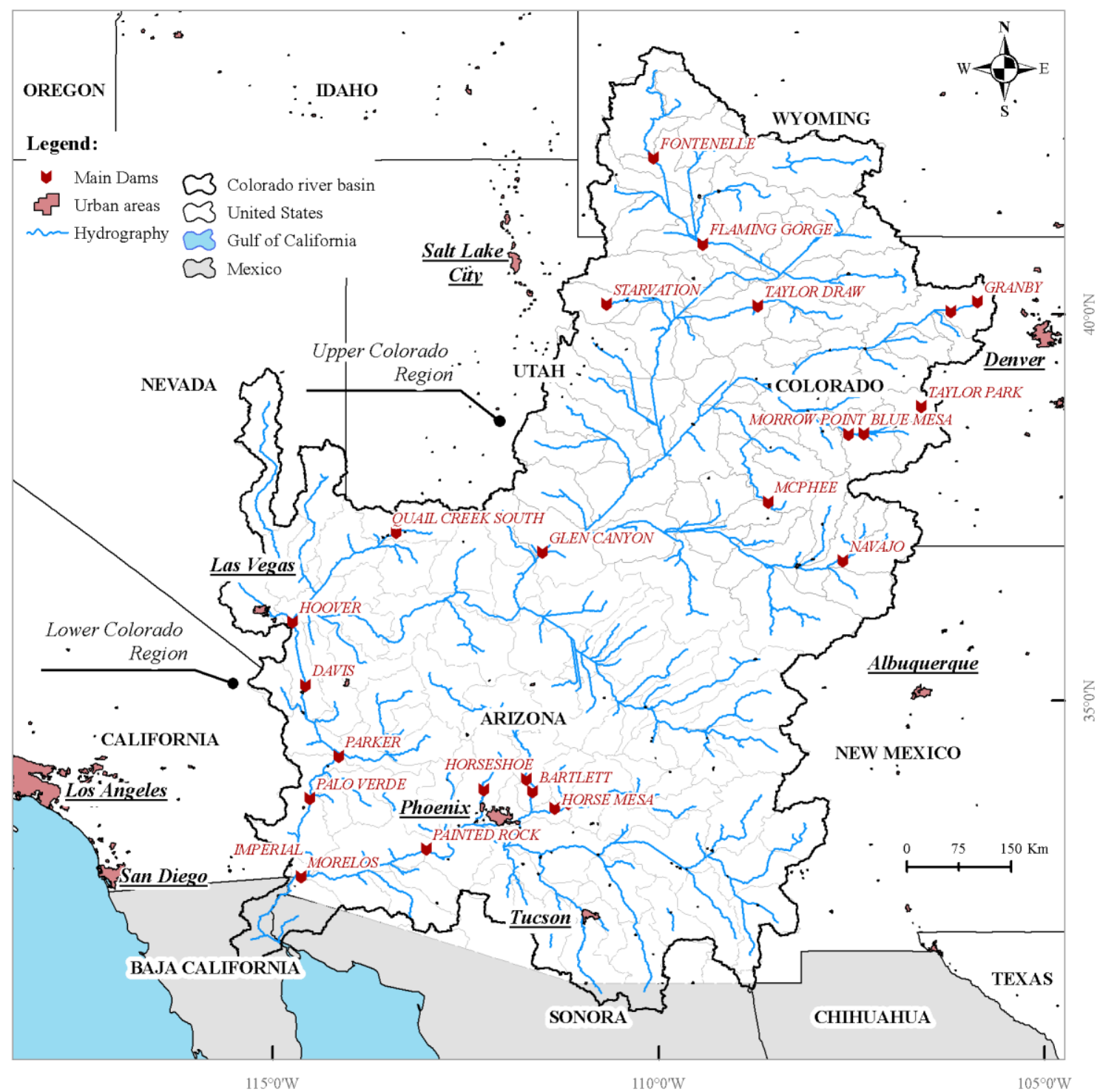

Figure 1.3 - Colorado River Basin showing the main dams (data source from National Atlas of The United States, 2013) 
Although, as recently as 150 years ago, the Colorado River was considered to be "wild and dangerous" and consequently explored in both fear and wonder by John Wesley Powell, it has long since been tamed. Being primarily a snowmelt-driven hydrologic system, 92 percent of the river's flow derives from snowmelt in upper basin states (Grafton et al., 2013). Today, the entire annual average flow of the Colorado River has been fully allocated under a complex set of legal agreements known as the "Law of the River" (Gleick, 2010). This collection of documents apportions the water and regulates the use of the Colorado River among its many users (USBR, 2013b) (Figure 1.4).

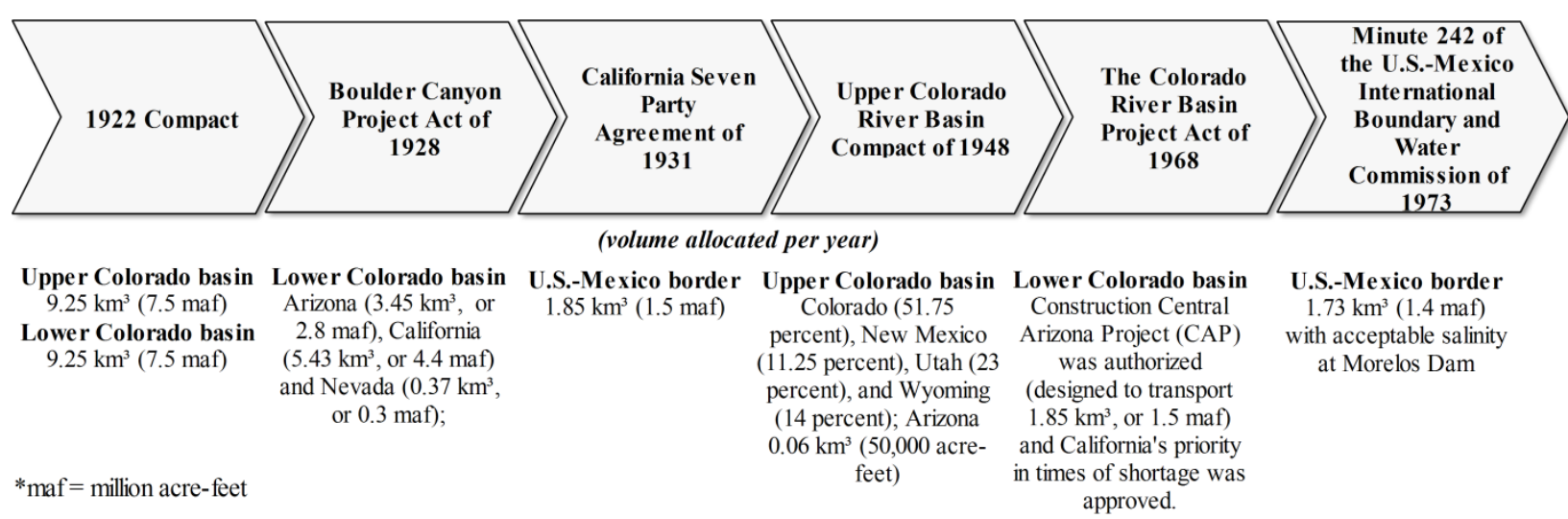

Figure 1.4 - Water allocation timeline of the Colorado River Basin (data source from USBR, 2013b)

Flows in the Colorado River were allocated in perpetuity, by an interstate compact in 1922. A treaty signed in 1944 obliges the United States to provide a minimum supply across the border to Mexico, which diverts that water to irrigation uses at the Morelos Dam close to the Mexico-California border (Grafton et al., 2013). Since the late 1990s (after the filling of Lake Powell), flows reaching the Colorado River delta have dropped to almost zero in most years (Gleick 2003), reducing the delta to about 5\% of its original area (Grafton et al., 2013). Native trees, including many over $6 \mathrm{~m}$ height, now account for only $20 \%$ of the species composition in this river stretch, having been largely replaced by species that are more salttolerant (Zamora-Arroyo et al., 2001).

Population growth and a changing climate will, no doubt, tax the future reliability of the Colorado River water supply (Rajagopalan et al., 2009). Recent studies project streamflow declines in the Colorado River ranging from 10\% to $20 \%$ for the Upper Colorado River basin and $20 \%$ to $40 \%$ for the Lower Colorado Basin by the mid- $21^{\text {st }}$ century, relative to $1900-1970$ historical conditions (Milly et al., 2008; Vano et al., 2013). Meanwhile, groundwater resources in the Southwest are already under significant stress levels (Gleeson et al., 2012) and, on top of this, the highest rates of population growth in the West are projected to occur in 
areas that are at risk due to climate change (Karl et al., 2009). Given these climate and demand stresses, water supply risk for the Colorado River is likely to increase significantly in the future (Rajagopalan et al., 2009).

It is interesting to note that, under the 2007 Shortage Sharing Guidelines (USBR, 2007), the different Colorado Basin States would be unequally affected under conditions resulting in an official declaration of shortage in Colorado River water supply (Wildman and Forde, 2012). Three levels of water delivery reductions have been established based on Lake Mead elevations ( $\left.<1025^{\prime}, 1025^{\prime}-1050^{\prime}, 1050^{\prime}-1075^{\prime}\right)$, and in all of them Arizona and Nevada would share close to $96 \%$ and $4 \%$ respectively of total water reductions (Gastelum and Cullom, 2013). Of the six water rights' priorities within Arizona, the fifth and sixth priority water uses will be eliminated first during shortage, followed by the fourth priority (CAP water) (ADWR, 2014). Within the CAP water supply there is a further priority system related to type of use: municipal/industrial and Indian priority water have the highest priority, followed by Non-Indian agriculture (NIA), with the lowest priority CAP water being excess pool water (typically used for groundwater recharge) (ADWR, 2014). If shortages were to continue for many years, Arizona and Nevada could face extremely difficult choices involving potential reductions in population or economic activity, whereas agricultural irrigation in the California desert and development of new water projects in the Upper Basin could likely be able to continue unabated (Wildman and Forde, 2012).

The Western U.S. is entering an era of water reallocation, in which part of the demand for new supplies will be satisfied by shifting water use from existing users to those with new demands (Pearce and Glennon, 2007). So a key mechanism to augment and allocate water to the domestic sector, without adding more pressure on current water sources (groundwater and rivers), will be to transfer agricultural rights to municipalities (Gastélum, 2012). The trend has been for the number of water rights transfers to increase in most areas and regions, but the total volume transferred has not been increasing at the same pace, and the average volumes per transaction has tended to decrease (Basta and Colby, 2010). Such transfers can be done as sale, lease, or donation, and facilitate movement of water among agricultural, municipal, industrial, energy, and environmental uses (WGA and WSWC, 2012). The price of water is highly variable both within and between western states, reflecting the localized nature of factors that affect water prices (Brown, 2006). An interstate market would give these arid states access to agricultural trading partners with different crops, planting patterns, and water needs (Wildman and Forde, 2012). 
In this context, the Water Bank mechanism in Arizona has been hailed as a major innovation in water management, and has changed the tenor of interstate negotiations in the Colorado River Basin. Due to the fact that Arizona needed to quickly utilize its full allocation during the 1980s and early 1990s, the Arizona Water Banking Authority (AWBA) was created in 1996 (Jacobs and Holway, 2004). Arizona has the right to consumptive use of up to 2.8 million acre-feet annually. Today, approximately 1.6 maf of this supply is apportioned to the Central Arizona Project (CAP) and Colorado River mainstream water users (ADWR 2013). One of the main objectives of AWBA is to protect Arizona's present and future water supply by banking portions of unused Arizona's entitlement. In addition AWBA has provided interstate water banking to assist Nevada and California. Excess CAP water is stored underground (for future recovery) to ensure reliable municipal water deliveries during future shortages (Jacobs and Holway, 2004). This water is stored either by direct injection into the aquifers (using mainly recharge basins) or by indirect recharge by means of irrigation districts using Colorado River water (which are converted into long term storage credits) (Gastelum and Cullom, 2013). In addition to storage by the AWBA, individual water providers and others have been storing water for future use, so a strong market for credits may emerge as water supplies get tighter (Megdal, 2012).

\section{Discussion and Conclusions}

American and Brazilian water laws have begun to shift towards management and allocation systems that recognize the limited nature of the water resource. This has happened slowly in North America and more abruptly in Brazil (Cassuto and Sampaio, 2011). Since the 1970s, the U.S. has made little progress, and has become increasingly fragmented and confused about fundamental management of the nation's water resources (Galloway Jr., 2011). Further, a conservative political culture defined by factors such as individualism and anti-regulation presents a major obstacle to implementation of conservation strategies to regulate water demand (Gástelum, 2012). It is important, therefore, to identify inflexible standards that undermine the ability to meet important future human needs (Auerbach, 2013).

Clearly, American water management has important characteristics that provide for higher levels of stability to the users, and is less bureaucratic and time-consuming than the 
Brazilian decision and operation process. However, some of the principles implemented within the Brazilian management framework could be beneficially incorporated into the American system, including: a) a more participatory approach involving government, users, and citizens; $b$ ) recognition of the economic value of bulk water as a finite natural resource (regardless of market value); and c) placing the highest priority on drinking water supply during times of shortage. In this regard, the Piracicaba River Basin Committee is an excellent example of how a decentralized decision process can help with complex water allocation processes (Porto, 1998). In particular, the post-diversion initiatives of the PCJ Committee helped to correct environmental problems caused by water transfer that had not been anticipated, or addressed and worked out, during the planning phase (Andrade et al., 2011). Further, the negotiation process strengthened the committees as a water management entity. From lessons learned, it can be safely said that upstream-downstream water and environmental management problems can be partially resolved by means of a clear definition of trade-offs that necessarily include economic, social, and environmental variables (Braga, 2000).

Davis (2007) discusses general differences in water resources management actions among developed and "in development" countries, and emphasizes that actions in less developed countries often involve institutional change (capacity building) and stakeholder engagement for provisioning of basic services for development needs, while actions in developed countries are usually focused on a re-examination of water management practices in the context of changing societal conditions and existing environmental restoration opportunities. Participatory processes in the information age may facilitate a socially equitable resource allocation even with stakeholder groups with strong political and economic power differentials, especially in settings with enforceable regulatory and legal frameworks. This strongly suggests the need for a re-examination of the American water system to incorporate a much stronger participatory or stakeholder-based process that will lead to more consensual and commonly agreed decisions, and ones that are consistent with local values.

The Brazilian system, in turn, could be benefited from certain characteristics of American water management, including reduced bureaucracy and a more efficient decision and operation process. Despite the important characteristics of decentralization and shared responsibility incorporated into the Brazilian water legislation, its practical application can be characterized by a bureaucratized, time-consuming, and sometimes, exclusionary practices by strong stakeholder groups, as demonstrated by experiences in the Paraíba do Sul and São Francisco River Basins (Ioris, 2009; Andrade et al., 2011). Nowadays, under the pressure of 
being the host of the world's biggest soccer event (2014 World Cup), the 2016 Olympic Games, and the current water shortage crisis in the most important economical region (Southeast), Brazil needs to conduct negotiations for short-term solutions through an extensive water management framework.

In the future, the U.S. and Brazil can both be expected to face substantial changes in the water cycle, coinciding with multiple stresses including population growth and competition for water supplies. While "hard-path" planners may erroneously equate the idea of using less water as being related to a loss of well-being (Gleick, 2003), "soft-path" solutions have the potential to improve the overall productivity of water use and deliver water services matched to the needs of end users, thereby reducing the pressure to seek sources of new supply (Gleick, 2002). Both countries have used soft-path solutions to ensure systems adaptability to future water demand and availability, including the use of water bank mechanisms and water rights transfers to supplement physical water transfer operations.

\section{Acknowledgements}

The investigation reported in this paper was conducted while the first author was a visiting student at The University of Arizona. The authors are grateful to Violeta Cabello (Universidad de Sevilla), Sergio Segura (Universidad de Sevilla), Zhao Yang (The University of Arizona), Kremena Boyanova (Bulgarian Academy of Sciences), Gloria Salmoral (Universidad Politécnica de Madrid) and Dr. Franck Poupeau (Centre National de la Recherche Scientifique), participants in the EU funded Sustainable Water ActioN (SWAN) Project, for sharing ideas that inspired this article, and to Derek Groenendyk (The University of Arizona) for technical contributions. The first author was supported by the São Paulo Research Foundation (FAPESP Processes 2011/11653-0, 2012/05515-6, and 2008/58161-1). The second and third authors obtained partial support from the EU funded SWAN project (grant 294947) under the EU $7^{\text {th }}$ Framework Programme. We thank the anonymous reviewers for their very helpful comments and suggestions. 


\section{References}

An, H., \& Eheart, J. (2006). Evaluation of Programs for Regulating Withdrawal of Surface Water under the Riparian Legal System. Journal of Water Resources Planning and Management, 132(5), 385-394. doi:10.1061/(ASCE)0733-9496(2006)132:5(385)

Andrade, J. G. P., Barbosa, P. S. F., Souza, L. C. A., \& Makino, D. L. (2011). Interbasin Water Transfers: The Brazilian Experience and International Case Comparisons. Water Resources Management, 25(8), 1915-1934. doi:10.1007/s11269-011-9781-6

Andreen, W. L., \& Jones, S. C. (2008). "The clean water act: A blueprint for reform." CRP White Paper No. 802, U of Alabama Public Law Research Paper No. 1236162, Rochester, NY.

Arizona Department ofWater Resources (ADWR). (2013). "Colorado river management." (Available at http://www.azwater.gov/AzDWR/StateWidePlanning/CRM/Overview.htm, accessed Jul. 30, 2013).

Arizona Department of Water Resources (ADWR). (2014). "Future waterdistribution." (Available http://www.azwater.gov/AzDWR/StateWidePlanning/CRM/FutureWaterDistribution.htm, accessed May 8, 2014).

Auerbach, D. A. (2013). Discussion: “America's Rivers and the American Experiment" by Martin W. Doyle. Journal of the American Water Resources Association, 49(4), 973-974. doi:10.1111/jawr.12045

Bark, R. H., \& Jacobs, K. L. (2009). Indian water rights settlements and water management innovations: The role of the Arizona Water Settlements Act. Water Resources Research, 45(5), W05417. doi:10.1029/2008WR007130

Basta, E., \& Colby, B. G. (2010). Water Market Trends: Transactions, Quantities, and Prices. Appraisal Journal, 78(1), 50-69.

Benetti, A. D., Lanna, A. E., \& Cobalchini, M. S. (2004). Current practices for establishing environmental flows in Brazil. River Research and Applications, 20(4), 427-444. doi:10.1002/rra.758

Benjamin, A. H., Marques, C. L., \& Tinker, C. (2005). "The water giant awakes: An overview of water law in Brazil.” Texas Law Rev., 83(7), 2185-2244.

Blaney, J. (2007). American Water Policy: "When the well is dry, we know the worth of water". Temple Journal of Science, Technology \& Environmental Law, 26(1), 75.

Braga, B. P. F. (2000). The Management of Urban Water Conflicts in the Metropolitan Region of São Paulo. Water International, 25(2), 208-213. doi:10.1080/02508060008686820

Braga, B. P. F. (2001). Integrated Urban Water Resources Management: A Challenge into the 21st Century. International Journal of Water Resources Development, 17(4), 581-599. doi:10.1080/07900620120094127

Braga, B. P. F., Flecha, R., Thomas, P., Cardoso, W., \& Coelho, A. C. (2009). Integrated Water Resources Management in a Federative Country: The Case of Brazil. International Journal of Water Resources Development, 25(4), 611-628. doi:10.1080/07900620903273432 
Braga, B. P. F., Porto, M. F. A., \& Silva, R. T. (2006). Water Management in Metropolitan São Paulo. International Journal of Water Resources Development, 22(2), 337-352. doi:10.1080/07900620600649850

Brazil. (1997). "Federal Law n. 9.433." National Water Resources Policy and the NationalWater Resource Management System, Brasília. (Available at http://www.planalto.gov.br/ccivil_03/Leis/L9433.htm, accessed Jul. 12, 2013).

Brazil. (2005). Conselho Nacional de Meio Ambiente-CONAMA Resolution n. 357, Brasília, Brazil. (Available at http://www.mma.gov.br/port/conama/res/res05/res35705.pdf, accessed May 23, 2013).

Brown, T. C. (2006). Trends in water market activity and price in the western United States. Water Resources Research, 42(9), W09402. doi:10.1029/2005WR004180

Burchi, S. (2012). A comparative review of contemporary water resources legislation: trends, developments and an agenda for reform. Water International, 37(6), 613-627. doi:10.1080/02508060.2012.694800

Cardwell, H. E., Cole, R. A., Cartwright, L. A., \& Martin, L. A. (2006). Integrated Water Resources Management: Definitions and Conceptual Musings. Journal of Contemporary Water Research \& Education, 135(1), 8-18. doi:10.1111/j.1936704X.2006.mp135001002.x

Carvalho, R. C. de, \& Magrini, A. (2006). Conflicts over Water Resource Management in Brazil: A Case Study of Inter-Basin Transfers. Water Resources Management, 20(2), 193213. doi:10.1007/s11269-006-7377-3

Cassuto, D. N., \& Sampaio, R. S. R. (2011). Water law in the United States and BrazilClimate change and two approaches to emerging water poverty. William Mary Environ. Law Policy Rev., 35(2), 371-412.

Christian-Smith, J., \& Allen, L. (2012). Legal and institutional framework of water management. A Twenty-First Century U.S. Water Policy, J. Christian-Smith, and P. H. Gleick, eds., Oxford University Press, New York, p.23-51.

Christian-Smith, J., P. H. Gleick, and H. Cooley (2012), U.S. Water Policy Reform. The World's Water, P. H. Gleick, ed., Island Press/Center for Resource Economics, Washington, D.C., p.143-155.

Curran, T. P., \& King, T. W. (1974). Nepa and a State's Role in Water Resources Management1. Journal of the American Water Resources Association, 10(1), 127-136. doi:10.1111/j.1752-1688.1974.tb00547.x

Davis, M. (2007). Integrated Water Resource Management and Water Sharing. Journal of Water Resources Planning and Management, 133(5), 427-445. doi:10.1061/(ASCE)07339496(2007)133:5(427)

Dellapenna, J. W. (2011). The Evolution of Riparianism in the United States. Marquette Law Review, 95, 53-90.

Doyle, M. W. (2012). America's Rivers and the American Experiment1. Journal of the American Water Resources Association, 48(4), 820-837. doi:10.1111/j.17521688.2012.00652.x

Elmore, A., Mustard, J., \& Manning, S. (2003). Regional patterns of plant community responses to changes in water: Owens Valley, California. Ecological Applications, 13(2), $443-460$. 
Engle, N. L., Johns, O. R., Lemos, M. C., \& Nelson, D. R. (2011). Integrated and adaptive management of water resources: tensions, legacies, and the next best thing. Ecology and Society, 16(1), 19.

Ferris, T. (2010). The Science of Liberty: Democracy, Reason, and the Laws of Nature. New York: HarperCollins.

Food and Agriculture Organization of the United Nations (FAO). (1995). Water policy reviews in practice - Reforming water resources policy: A guide to methods, processes and practices, (Paper n. 52) Rome: FAO. (Available at http://www.fao.org/docrep/v7160e/v7160e08.htm, accessed Jul. 25, 2013).

Foti, R., Ramirez, J. A., and Brown, T. C. (2012). Vulnerability of U.S. water supply to shortage: A technical document supporting the forest service 2010. (Rep. RMRS-GTR295), Fort Collins, CO: U.S. Dept. of Agriculture, Forest Service, Rocky Mountain Research Station.

France (1992). Federal Law of Jan 3 1992. French Water Act. (Available at http://semide.oieau.fr/EN/topics/lois/watlaw92.htm, accessed Jul. 20, 2013).

Galloway Jr, G. E. (2011). A Plea for a Coordinated National Water Policy. Bridge, 41(4), $37-46$.

Gastélum, J. R. (2012). Analysis of Arizona's Water Resources System. International Journal of Water Resources Development, 28(4), 615-628. doi:10.1080/07900627.2011.625524

Gastélum, J. R., \& Cullom, C. (2013). Application of the Colorado River Simulation System Model to Evaluate Water Shortage Conditions in the Central Arizona Project. Water Resources Management, 27(7), 2369-2389. doi:10.1007/s11269-013-0292-5

Gerlak, A. K. (2006). Federalism and U.S. Water Policy: Lessons for the Twenty-First Century. Publius: The Journal of Federalism, 36(2), 231-257. doi:10.1093/publius/pji032

Gleeson, T., Wada, Y., Bierkens, M. F. P., \& van Beek, L. P. H. (2012). Water balance of global aquifers revealed by groundwater footprint. Nature, 488(7410), 197-200. doi:10.1038/nature11295

Gleick, P. H. (2002). Water management: Soft water paths. Nature, 418(6896), 373-373. doi:10.1038/418373a

Gleick, P. H. (2003). Global Freshwater Resources: Soft-Path Solutions for the 21st Century. Science, 302(5650), 1524-1528. doi:10.1126/science.1089967

Gleick, P. H. (2010). Roadmap for sustainable water resources in southwestern North America. Proceedings of the National Academy of Sciences, 107(50), 21300-21305. doi:10.1073/pnas.1005473107

Gleick, P. H. (2012). The World's Water Volume 7: The Biennial Report on Freshwater Resources. Washington, D.C.: Island Press/Center for Resource Economics.

Glennon, R. G., \& Pearce, M. J. (2007). Transferring mainstem Colorado river water rights: the Arizona experience. Arizona Law Rev., 49(2), 235-256.

Global Water Partnership (GWP). (2009). Handbook for IWRM in basins. 〈Available at http://www.gwptoolbox.org/index2.php?option=com_reference\&reference_id=174\&pop= 1, accessed July 30, 2013). 
Gohari, A., Eslamian, S., Mirchi, A., Abedi-Koupaei, J., Massah Bavani, A., \& Madani, K. (2013). Water transfer as a solution to water shortage: A fix that can Backfire. Journal of Hydrology, 491, 23-39. doi:10.1016/j.jhydrol.2013.03.021

Grafton, R. Q., Pittock, J., Davis, R., Williams, J., Fu, G., Warburton, M., ... Quiggin, J. (2013). Global insights into water resources, climate change and governance. Nature Climate Change, 3(4), 315-321. doi:10.1038/nclimate1746

Haddad, E. A., and Teixeira, E. (2013). Economic impacts of natural disasters in megacities: The case of floods in São Paulo, Brazil. Nucleo de economia regional e urbana da Universidade de Sao Paulo (NEREUS). (Available at http://www.usp.br/nereus/wpcontent/uploads/TD_Nereus_04_2013b.pdf, accessed Aug. 10, 2013).

Hazard, J., and Shively, D. (2011). Conjunctive management of surface and ground water resources in the western United States. Report, Univ. of Montana, Missoula, MT, (Available

http://dnrc.mt.gov/wrd/water_mgmt/clarkforkbasin_taskforce/pdfs/conjunctive_watermg mt_western_us.pdf, accessed Sept. 16, 2013).

Hirata, R., Suhogusoff, A., \& Fernandes, A. (2007). Groundwater resources in the State of São Paulo (Brazil): the application of indicators. Anais da Academia Brasileira de Ciências, 79(1), 141-152. doi:10.1590/S0001-37652007000100016

Hu, X., \& Eheart, J. (2014). Mechanism for Fair Allocation of Surface Water under the Riparian Doctrine. Journal of Water Resources Planning and Management, 140(5), 724 733. doi:10.1061/(ASCE)WR.1943-5452.0000369

Huitema, D., Mostert, E., Egas, W., Moellenkamp, S., Pahl-Wostl, C., \& Yalcin, R. (2009). Adaptive Water Governance: Assessing the Institutional Prescriptions of Adaptive (Co)Management from a Governance Perspective and Defining a Research Agenda. Ecology and Society, 14(1), 26.

Ioris, A. A. R. (2009). Water reforms in Brazil: opportunities and constraints. Journal of Environmental Planning and Management, 52(6), 813-832. doi:10.1080/09640560903083756

Jacobs, K. L., \& Holway, J. M. (2004). Managing for sustainability in an arid climate: lessons learned from 20 years of groundwater management in Arizona, USA. Hydrogeology Journal, 12(1), 52-65. doi:10.1007/s10040-003-0308-y

Karl, T. R., Melillo, J. M.; and Peterson, T. C. (2009). Global Climate Change Impacts in the United States. Cambridge University Press, New York, 196p. (Available at http://downloads.globalchange.gov/usimpacts/pdfs/climate-impacts-report.pdf, accessed Jul. 24, 2013).

Klein, C. A., Angelo, M. J., \& Hamann, R. (2009). Modernizing Water Law: The Example of Florida. Fla. L. Rev., 61, 403.

Libecap, G. D. (2009). Chinatown Revisited: Owens Valley and Los Angeles-Bargaining Costs and Fairness Perceptions of the First Major Water Rights Exchange. Journal of Law, Economics, and Organization, 25(2), 311-338. doi:10.1093/jleo/ewn006

Megdal, S. B. (2012). Arizona groundwater management. Water Rep., 104, 9-15.

Micklin, P. P. (1984). Inter-basin water transfers in the United States. International Journal of Water Resources Development, 2(2-3), 37-65. doi:10.1080/07900628408722314 
Milly, P. C. D., Betancourt, J., Falkenmark, M., Hirsch, R. M., Kundzewicz, Z. W., Lettenmaier, D. P., \& Stouffer, R. J. (2008). Stationarity Is Dead: Whither Water Management? Science, 319(5863), 573-574. doi:10.1126/science.1151915

National Atlas of the United States. (2013). National atlas data download. (Available at http://www.nationalatlas.gov/atlasftp.html, accessed Jul. 31, 2013).

National Geographic (NatGeo). (2013). Colorado River. (Available at http://environment.nationalgeographic.com/environment/freshwater/colorado-riverzoomifier/, accessed Jul. 20, 2013).

National Research Council (NRC). (1999). New directions in water resources planning for the U.S. army corps of engineers, The National Academies Press, Washington, DC. (Available at http://www.nap.edu/openbook.php?record_id=6128\&page=R1, accessed Jul. 12, 2013).

National Water Agency (ANA). (2009). The implementation of water charges and water agency in the Piracicaba, Capivari and Jundiaí river basins. Brasília.

National Water Agency (ANA). (2010). Brazilian Atlas: An overview of the urban water supply. ANA/Engecorps/Cobrape, Brasília, (Available at http://atlas.ana.gov.br/Atlas/downloads/atlas/Resumo\%20Executivo/Atlas\%20Brasil\%20\%20Volume\%201\%20-\%20Panorama\%20Nacional.pdf, accessed May 23, 2013).

Nion, G. (2009). Water framework directive and water policies in France: Evolution and tools for a rational use of water resources. Technological perspectives for rational use of water resources in the Mediterranean region, L. Mandi, I. Martín, A. Rabi, R. Rodríguez, G. Trisorio-Liuzzi, and M. El Moujabber, eds., CIHEAM, Bari, 221-230, $\langle$ http://om.ciheam.org/om/pdf/a88/00801197.pdf (Jul. 03, 2013).

Padowski, J. C., \& Jawitz, J. W. (2012). Water availability and vulnerability of 225 large cities in the United States. Water Resources Research, 48(12), W12529. doi:10.1029/2012WR012335

Pearce, M. (2003). Interactive groundwater/surface-water regulation in Arizona. Southwest Hydrology, 2(4), 16-17.

Piracicaba, Capivari e Jundiaí Rivers Basin Committee (PCJ). (2011).Plano das bacias hidrográficas dos rios Piracicaba, Capivari e Jundiaí 2010-2020: Relat'orio síntese, Cobrape, São Paulo. (Available at http://www.comitepcj.sp.gov.br/download/PB/PCJ_PB2010-2020_Sintese.pdf, accessed Jan. 10, 2013).

Porto, M. (1998). The Brazilian Water Law: A New Level of Participation and Decision Making. International Journal of Water Resources Development, 14(2), 175-182. doi:10.1080/07900629849385

Rajagopalan, B., Nowak, K., Prairie, J., Hoerling, M., Harding, B., Barsugli, J., ... Udall, B. (2009). Water supply risk on the Colorado River: Can management mitigate? Water Resources Research, 45(8), W08201. doi:10.1029/2008WR007652

Robison, J. A., \& Kenney, D. S. (2012). Equity and the Colorado River Compact. Environmental Law, 42, 1157-1209.

Sao Paulo State. (1994). Law No. 9034. Water resources state plan. (Available at http://www.jusbrasil.com.br/legislacao/174303, accessed May 1, 2013). 
Schutz, J. R. (2012). Why the Western United States' prior appropriation water rights system should weather climate variability. Water International, 37(6), 700-707. doi:10.1080/02508060.2012.726544

Seaber, P. R., Kapinos, F. P., \& Knapp, G. L. (1987). Hydrologic unit maps. (Water Supply Paper 2294) U.S. Geological Survey.

Shiklomanov, I. A. (2000). Appraisal and Assessment of World Water Resources. Water International, 25(1), 11-32. doi:10.1080/02508060008686794

Smith, B. W. (2009). Water as a Public Good: The Status of Water Under the General Agreement on Tariffs and Trade. Cardozo Journal of International and Comparative Law, 17(291), 291-314.

Speed, R., Li, Y., Le Quesne, T., Pegram, G., and Zhiwei, Z. (2013). "Basin water allocation planning. principles, procedures and approaches for basin allocation planning." Series on strategic water management, UNESCO, Paris. (Available at http://www.adb.org/sites/default/files/pub/2013/basic-water-allocation-planning.pdf, accessed Jun. 30, 2013).

The Guardian. (2014). São Paulo faces a critical water shortage as the World Cup prepares to kick off, May 21th 2014. (Available at http://www.theguardian.com/sustainablebusiness/sao-paulo-water-shortage-world-cup, accessed May 21, 2014).

The Nature Conservancy (TNC). (2010). Great rivers partnership. Rep.:The first five years, TNC, (Available at http://www.nature.org/ourinitiatives/habitats/riverslakes/programs/great-riverspartnership/grp-5-year-report.pdf, accessed Jul. 29, 2013).

The Nature Conservancy (TNC). (2012). Nature protects nourishes strengthens inspires empowers quenches matters. 2012 Annual Rep. (Available at http://www.nature.org/media/brasil/relatorio_anual_2012.pdf, accessed Sep. 6, 2013).

Thompson, S. A. (1999). Water Use: Management and Planning in the United States. Academic Press: San Diego, California.

U.S. Bureau of Reclamation (USBR). (2007). Colorado River interim guidelines for lower basin shortages and coordinated operations of Lake Powell and Lake Mead: Final environmental impact statement. U.S. Dept. of the Interior, Boulder City, Nevada, (Available at http://www.usbr.gov/lc/region/programs/strategies/feis/index.html, accessed Jun. 20, 2014).

U.S. Bureau of Reclamation (USBR). (2013a). Projects. (Available at http://www.usbr.gov/projects/projects.jsp, accessed Jul. 30, 2013).

U.S. Bureau of Reclamation (USBR). (2013b). The law of Colorado River. (Available at http://www.usbr.gov/lc/region/g1000/lawofrvr.html, accessed Jul 20,2013).

U.S. Bureau of Reclamation (USBR). (2013c). Colorado River basin water supply and demand study. Reclamation: Managing water in the west, U.S. Dept. of the interior, (Available at http://www.usbr.gov/lc/region/programs/crbstudy/FactSheet_June2013.pdf, accessed May 13, 2014).

U.S. Department of Interior (USDOI). (2013). Water in the west. (Available at http://www.nps.gov/nr/travel/ReclamationDamsAndWaterProjects/Water_In_The_West.h tml, accessed Jul. 16, 2013). 
Valdes, J., \& Maddock III, T. (2010). Conjunctive Water Management in the US Southwest. In G. Schneier-Madanes \& M.-F. Courel (Orgs.), Water and Sustainability in Arid Regions (p. 221-244). Springer Netherlands.

Vano, J. A., Udall, B., Cayan, D. R., Overpeck, J. T., Brekke, L. D., Das, T., ... Lettenmaier, D. P. (2013). Understanding Uncertainties in Future Colorado River Streamflow. Bulletin of the American Meteorological Society, 130625085810007. doi:10.1175/BAMS-D-1200228.1

Veiga, L. B. E., \& Magrini, A. (2013). The Brazilian Water Resources Management Policy: Fifteen Years of Success and Challenges. Water Resources Management, 27(7), 22872302. doi:10.1007/s11269-013-0288-1

Volkman, J. M., \& Lee, K. N. (1988). Within the Hundredth Meridian: Western States and Their River Basins in a Time of Transition. University of Colorado Law Review, 59, 551578.

Western Governors' Association (WGA), and Western States Water Council (WSWC). (2012). Water Transfers in the West. 〈http://www.westgov.org/initiatives/water/102articles/initiatives/373-water-transfers $\rangle$ (May 12, 2014).

Whately, M., and Cunha, P. (2007). Cantareira 2006: a view of the biggest water source in the Metropolitan Region of São Paulo), Instituto Socioambiental (Socioambiental Institute ISA), São Paulo. (in Portuguese). (Available at http://www.socioambiental.org/banco_imagens/pdfs/10289.pdf, accessed April 14, 2014).

Wildman, R. A., \& Forde, N. A. (2012). Management of Water Shortage in the Colorado River Basin: Evaluating Current Policy and the Viability of Interstate Water Trading1. JAWRA Journal of the American Water Resources Association, 48(3), 411-422. doi:10.1111/j.1752-1688.2012.00665.x

World Bank (2014a). World Development Indicators: Freshwater $\langle$ http://wdi.worldbank.org/table/3.5〉 (Jun. 30, 2014)

World Bank (2014b). World Development Indicators: GDP per capita (current US\$) (Available at http://data.worldbank.org/indicator/NY.GDP.PCAP.CD/countries/BRUS?display=default, accessed Jun. 30, 2014)

World Bank (2014c). World Development Indicators: Population dynamics (Available at http://wdi.worldbank.org/table/2.1, accessed Jun. 30, 2014)

Wurbs, R. A. (2013). Water allocation systems. In R. A. Wurbs, Water resources planning, development and management, InTech.

Yevjevich, V. (2001). Water Diversions and Interbasin Transfers. Water International, 26(3), 342-348. doi:10.1080/02508060108686926

Zamora-Arroyo, F., Nagler, P. L., Briggs, M., Radtke, D., Rodriquez, H., Garcia, J., ... Glenn, E. P. (2001). Regeneration of native trees in response to flood releases from the United States into the delta of the Colorado River, Mexico. Journal of Arid Environments, 49(1), 49-64. doi:10.1006/jare.2001.0835 


\title{
CHAPTER 2
}

\section{A BLUE/GREEN WATER-BASED ACCOUNTING FRAMEWORK FOR ASSESSMENT OF WATER SECURITY*}

\begin{abstract}
*A modified version of this chapter has been published as: Rodrigues, D. B. B., Gupta, H. V., \& Mendiondo, E. M. (2014). A blue/green water-based accounting framework for assessment of water security, Water Resources Research, 50, doi:10.1002/2013WR014274. (Journal impact factor: 3.709; Qualis CAPES: A1)
\end{abstract}

\begin{abstract}
A comprehensive assessment of water security can incorporate several water-related concepts, while accounting for Blue and Green Water (BW and GW) types defined in accordance with the hydrological processes involved. Here, we demonstrate how a quantitative analysis of provision probability and use of BW and GW can be conducted, so as to provide indicators of water scarcity and vulnerability at the basin level. To illustrate the approach, we use the Soil and Water Assessment Tool (SWAT) to model the hydrology of an agricultural basin (291 $\mathrm{km}^{2}$ ) within the Cantareira water supply system in Brazil. To provide a more comprehensive basis for decision-making, we analyze the BW- and GW-Footprint components against probabilistic levels (50th- and 30th-percentile) of freshwater availability for human activities, during a 23-year period. Several contrasting situations of BW provision are distinguished, using different hydrological-based methodologies for specifying monthly Environmental Flow Requirements (EFRs), and the risk of natural EFR violation is evaluated by use of a freshwater provision index. Our results reveal clear spatial and temporal patterns of water scarcity and vulnerability levels within the basin. Taking into account conservation targets for the basin, it appears that the more restrictive EFR methods are more appropriate than the method currently employed at the study basin. The Blue/Green water-based accounting framework developed here provides a useful integration of hydrologic, ecosystem and human needs information on a monthly basis, thereby improving our understanding of how and where water-related threats to human and aquatic ecosystem security can arise.
\end{abstract}

Keywords: Water scarcity; Water vulnerability; Environmental Flow Requirements, SWAT model 


\section{Introduction}

Uncertainties regarding future climate, trends in population growth, and changes in lifestyle, are likely to promote significant increases in risks associated with environmental and human water security. It has been reported that $80 \%$ of the world's population is exposed to high levels of water security risk, with consumptive water use being one of the strongest stressors (Vörösmarty et al., 2010). Currently, agriculture accounts for 70 percent of global freshwater withdrawals, and more than 90 percent of its consumptive use (FAO, 2012). It has been estimated that there will, by 2050 , be a 70 percent increase in demand for food production globally (relative to 2009 levels), and up to a 100 percent increase in developing countries (FAO, 2011). In the context of Brazil, Oki and Kanae (2006) have reported that significant levels of water scarcity already exist for some regions, and in 2010, the National Water Agency predicted that one half of Brazilian cities will experience significant levels of water stress by 2015 (taking into account population growth rates, availability of water resources, and current infrastructure condition of these cities), which would affect approximately 139 million inhabitants (ANA, 2010). Recently, Southeastern Brazil unexpectedly experienced extremely low rainfall during the rainy season, resulting in threats to water security in the Metropolitan Region of Sao Paulo city (home to approximately 20 million inhabitants and the most important economic region in Brazil), so that emergency actions were needed to guarantee supply - see The Guardian, 21 May 2014.

The gap between water demand and availability is usually described by concepts of stress, shortage, and scarcity, which are respectively related to: accessibility problems, population-to-volume ratio, and whatever reason (i.e. scarcity is a general term) (Rockström et al., 2009). Water security, in contrast, refers to acceptable levels of water-related risks while balancing support for livelihood, human well-being, socio-economic development, and ecosystem functioning (Grey and Sadoff, 2007; Bakker, 2012). Policies for national water security must consider not only the availability of water resources, but also their interdependence with other basic societal needs such as food, energy and climate, while seeking an equitable distribution among the actors involved (Zeitoun, 2011). So, the level and extent of water security (or insecurity) is characterized by interactions between societal needs, ecosystem functioning, and hydroclimatic conditions (Scott et al., 2013). Meanwhile, the new Scientific Decade (2013-2022) entitled "Panta Rhei-Everything Flows", being promoted by the International Association of Hydrological Sciences (IAHS), is designed to focus attention 
on the role that hydrological systems play as a changing interface between environment and society, and whose dynamics are essential for determining water security, human safety and sustainable development (Montanari et al., 2013).

The freshwater cycle can be partitioned into two kinds - 'green' and 'blue' water - in accordance with the hydrological processes and storage type involved. Blue water flows through either on or below the land surface, and can be stored in aquifers, lakes, and reservoirs, while Green water refers to the portion of precipitation that infiltrates to become soil moisture or remains temporarily on top of the soil or vegetation, then eventually returns to the atmosphere via transpiration and evaporation (Falkenmark and Rockström, 2006; Rockström et al., 2009). The consumption of each of these kinds of water - blue and green by human activities, has been incorporated into the Water Footprint concept developed by Arjen Hoekstra (Hoekstra \& Hung, 2002; Hoekstra et al., 2011). Accordingly, the Blue Water Footprint (BW-Footprint) represents consumptive use from blue water sources (surface water and groundwater bodies), and the Green Water Footprint (GW-Footprint) represents the fraction of green water that is consumed by agricultural lands (e.g. evapotranspiration from crop and permanent pasture areas) (Hoekstra et al., 2011), which is also called "productive vapor flows" (Rockström et al., 2009). Note that the BW- and GW-Footprint components represent the consumptive part of the Water Footprint concept, which is also composed by another component (Grey Water Footprint) and indirect water use (virtual water) (A. Hoekstra, personal communication 2013).

The environmental sustainability of $B W$ - and $G W$-Footprint components can be evaluated (at the river basin scale) in relation to freshwater provision levels (water available for human activities), thereby facilitating the identification of hotspots; i.e., times of the year (such as dry periods) and locations (e.g., specific sub-catchments) at which problems of water conflict are more likely to occur (Hoekstra et al., 2011). Specifically, Blue Water provision level depends on the reference values established as the Environmental Flow Requirement (EFR) necessary for 'supporting' ecosystem services (Honrado et al., 2013). These values quantify the amounts of water that must be kept flowing down a river to maintain the quality, quantity and temporality required to achieve environmental goals. The EFR specifies the equilibrium levels for specific situations, taking into account river uses by the local population and the river conditions considered acceptable by them (O'Keefe et al., 2009). Consequently, there are on the order of 200 different eco-hydrological techniques for EFR establishment (Tharme, 2003); various Brazilian river committees and water footprint 
assessment studies have used a variety of hydrological-based methods (Benetti et al., 2004; Hoekstra et al., 2011, 2012; Zeng et al., 2012). Note that EFR accounting must be performed using flow time series that represent naturalized conditions as closely as possible (Van Loon and Van Lanen, 2013).

Joint management of blue and green water is useful for identifying critical hydrological situations where water abstractions, Environmental Flow and Crop Water requirements need to be met with reduced water resources, and for design of management practices needed to maintain required levels of Blue Water flow to downstream users (Calder, 2007) so as to decrease blue water dependency. Such considerations are incorporated into the 'Integrated Land and Water Resource Management' system, which redefines 'Integrated Water Resource Management' by considering not just the Blue Water resource, but also the entire water balance (including the Blue/Green water cycle) as being "manageable" (Falkenmark and Rockström, 2006).

If historic patterns of land and water use persist, the capacity of ecosystems to sustain freshwater services (such as provisioning and supporting) has been strongly compromised throughout much of the world (Vörösmarty et al., 2005). Academic research on issues of water security tends to be relatively poorly integrated with the needs of policy-makers and practitioners (Bakker, 2012). Vulnerability and risk assessment have been identified, therefore, as critical aspects of the water security agenda (Bakker, 2012). In particular, water vulnerability assessments can help to identify potential weaknesses in water system security (ASDWA and NRWA, 2002), by evaluating the ability of available water sources to meet projected water abstraction needs under conditions of water stress (Padowski and Jawitz, 2012).

Water scarcity and vulnerability are both time-dependent phenomena, varying within the year and from year to year in accordance with climatic variability. Standardized assessments of scarcity and vulnerability can provide a useful basis by which societies can increase their water security and better prepare for future conditions (Padowski and Jawitz, 2012; Sullivan, 2011). In this paper, we present a blue/green water-based accounting framework that integrates concepts relevant to water security assessment, and which can help diagnose primary water-related threats to human and aquatic ecosystem security. To illustrate the approach, we demonstrate how a quantitative analysis of use (abstraction and consumption) and provision probability of BW and GW can be conducted, so as to provide indicators of water scarcity and vulnerability for a socially relevant study basin in the Southeast of Brazil. 


\section{Materials and Methods}

\subsection{Study area}

We apply the blue/green water-based accounting framework, through a process of hydrological modeling and estimation of water scarcity and vulnerability indicators (Figure $2.1)$, to the $291 \mathrm{~km}^{2}$ Cachoeira river basin $\left(46^{\circ} 16^{\prime} 18^{\prime \prime} \mathrm{W} 23^{\circ} 6^{\prime} 25^{\prime \prime} \mathrm{S}\right.$ to $46^{\circ} 0^{\prime} 21^{\prime \prime} \mathrm{W} 22^{\circ} 50^{\prime} 56^{\prime \prime} \mathrm{S}$, Figure 2.2), located upstream of the Cachoeira reservoir, within the Piracicaba river basin. The study basin was divided into two upstream sub-basins (A and B), which are the main contributor areas for the basin outlet, including the headwaters of the basin and having their outlets upstream of the confluence of the tributary and main channel (Figure 2.2).

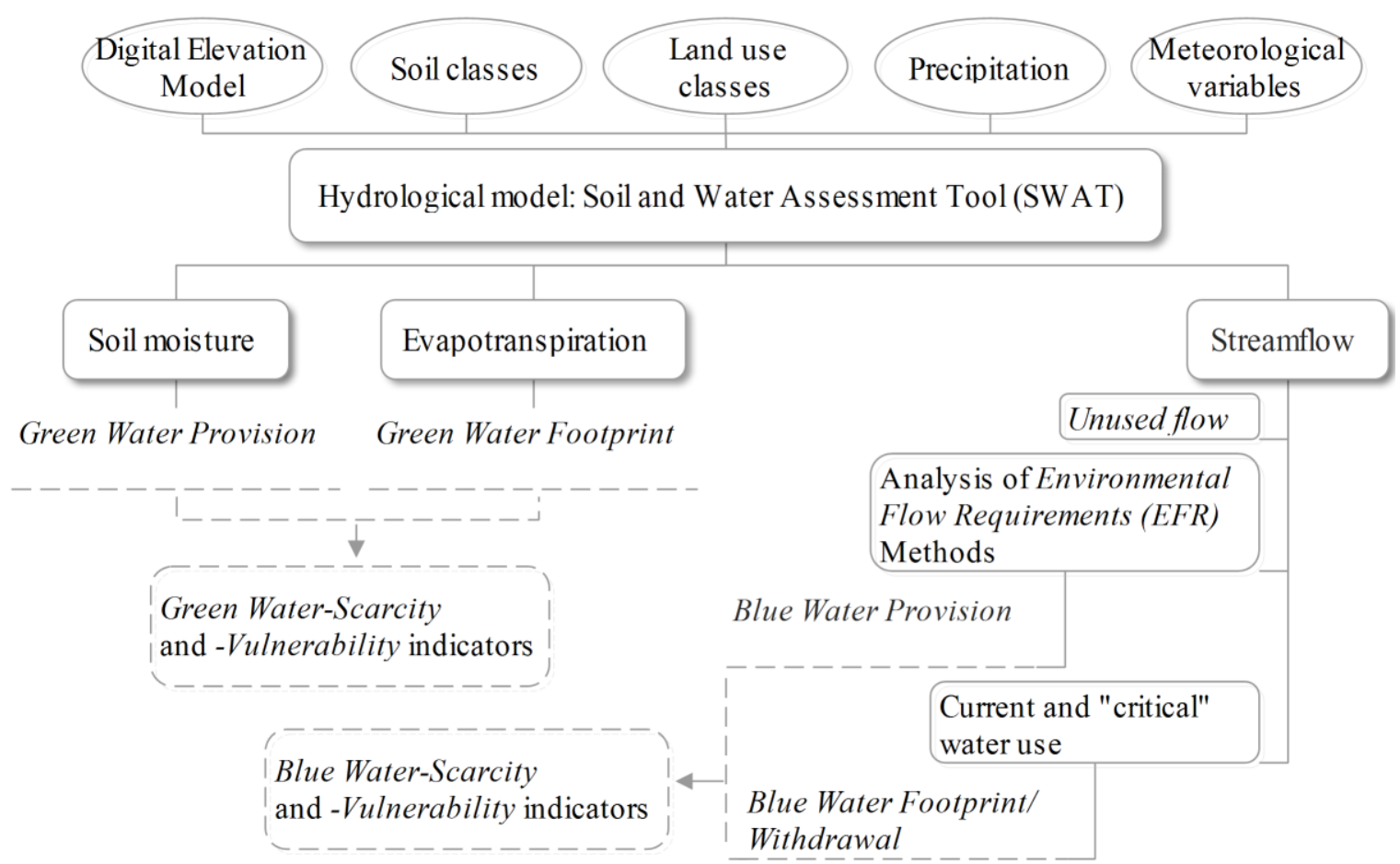

Figure 2.1 - A Blue/Green Water-based accounting framework for assessment of water security

This study basin has significant economic and social relevance, because it is part of the Cantareira System of water supply, which involves a sequence of four reservoirs used to supply water to about 9 million people in the Metropolitan Region of Sao Paulo. The Cachoeira reservoir contributes about $15 \%$ of the total water supplied by the Cantareira system (Whately \& Cunha, 2007). The river basin plan that covers this basin is called the Piracicaba-Capivari-Jundiai River Basin Plan, and considers the region for "Protection and Control" (PCJ, 2011). The water quality goals for the water bodies within this region refer to 
the "class 1" of Brazilian CONAMA Resolution no. 357/2005 (Brazil, 2005), which requires that water quality for drinking water and other specific uses be achievable with only simplified treatment (PCJ, 2011). Such classification of water bodies in different classes of use is one of the instruments of Brazilian Water Resources Policy (Law 9433/1997) (Porto, 1998), and intends to balance specific water quality standards and waste treatment costs, either to keep the standards or to restore the quality of degraded rivers and lakes (Porto and Porto, 2002).

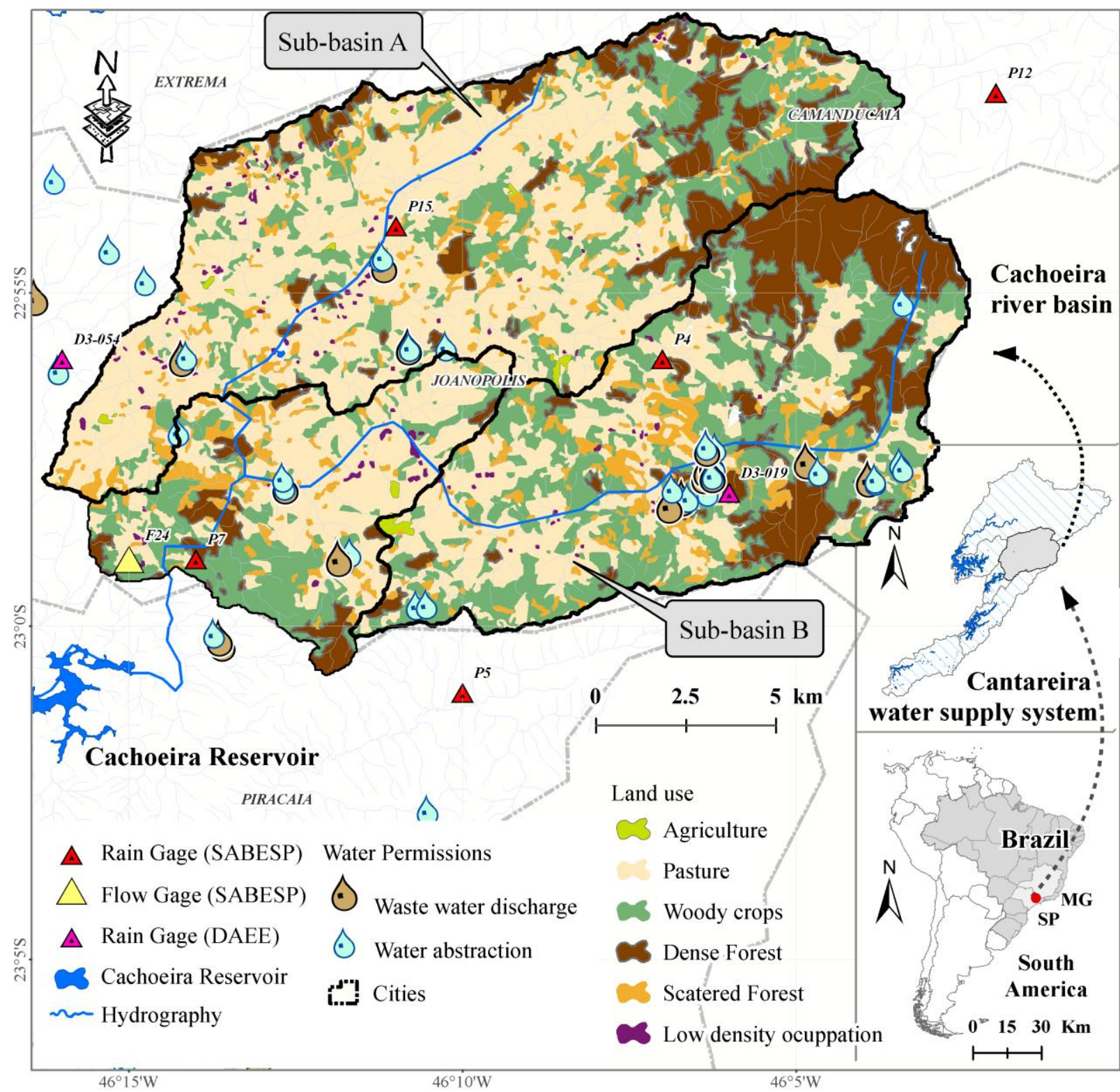

Figure 2.2 - Study area represented by Cachoeira river basin $\left(291 \mathrm{~km}^{2}\right)$, which is divided into two upstream sub-basins (A and B) and covered by land use map correspondent to reference year 2010 . The locations of water permits and hydrological gages are shown 
The Land Use/Land Cover (LULC) of the study area is essentially agricultural. Extensive cattle husbandry and woody crops, such as eucalyptus and pine trees, are the prevailing activity (Table 2.1). The LULC classifications were developed using Landsat Thematic Mapper (TM) images corresponding to reference year 2010. The Brazilian Soil Classification System (based on USDA, 1975 and FAO/Unesco, 1974) (Embrapa, 2006) indicates the soil classes to be: dystrophic Red-Yellow Latosol (LVA) (64.7\%); dystrophic Haplic Cambisol (CXbd) (14.3\%); and Dystrophic Red-yellow Argisol (PVAd) (21.0\%). The first soil class is defined as clay, and the second and third as sandy clay. The climate is humid subtropical (Cwa), characterized by warm/humid summers and cool/dry winters, in accordance with the updated Köppen-Geiger climate classification (Peel et al., 2007).

Table 2.1 - Land use distribution for the Cachoeira river basin and sub-basins

\begin{tabular}{llll}
\hline & Sub-basin & & \\
\cline { 2 - 3 } Land use & A & B & Entire basin \\
\hline Low density occupation & $<1 \%$ & $<1 \%$ & $<1 \%$ \\
Agriculture (annual crops) & $<1 \%$ & $<1 \%$ & $<1 \%$ \\
Pasture & $55.9 \%$ & $31.7 \%$ & $46.3 \%$ \\
Woody crops & $23.7 \%$ & $36.7 \%$ & $29.5 \%$ \\
Dense Forest & $11.9 \%$ & $23.7 \%$ & $15.8 \%$ \\
Scattered Forest & $7.2 \%$ & $6.8 \%$ & $7.2 \%$ \\
Total area & $136 \mathrm{~km}^{2}$ & $107 \mathrm{~km}^{2}$ & $291 \mathrm{~km}^{2}$ \\
\hline
\end{tabular}

\subsection{Hydrological Modeling}

\subsubsection{Model data input and processing}

The hydrological processes related to Blue and Green Water cycles were simulated with the Soil and Water Assessment Tool (SWAT) model (Arnold et al., 1998), using the ArcSWAT 2012 version and ArcGIS 10.0 (service pack 5) software (ESRI, 2010). This model is widely used for hydrological and non-point source pollution assessment (Gassman et al., 2007). Data required for the model, including the digital elevation model (DEM), soil properties, vegetation cover, meteorological and hydrological time series were obtained from several sources as detailed in Table 2.2. 
Table 2.2 - Input data sources for SWAT modeling of the Cachoeira river basin

\begin{tabular}{|c|c|c|c|}
\hline Data type & Description/properties & Scale & Source \\
\hline Current land use & $\begin{array}{l}\text { Landsat Thematic Mapper } \\
\text { (TM) image (year 2010) }\end{array}$ & $30 \times 30 \mathrm{~m}$ & NGO Terceira Via \\
\hline Topography & $\begin{array}{l}\text { Contour map (interval of } \\
20 \text { meters) converted to } \\
\text { Digital Elevation Model - } \\
\text { DEM }\end{array}$ & $\begin{array}{l}1: 50.000 \\
\text { converted to } \\
20 \times 20 \mathrm{~m}\end{array}$ & $\begin{array}{l}\text { The Brazilian Institute of Geography and } \\
\text { Statistics (IBGE), digitalized by } \\
\text { SocioAmbiental Institute (ISA) }\end{array}$ \\
\hline Hydrograph & $\begin{array}{l}\text { Contour and hydrographic } \\
\text { map }\end{array}$ & $1: 50.000$ & $\begin{array}{l}\text { The Brazilian Institute of Geography and } \\
\text { Statistics (IBGE), digitalized by } \\
\text { Socioambiental Institute (ISA) }\end{array}$ \\
\hline \multirow[t]{2}{*}{ Soils } & Soil map of São Paulo state & $1: 500.000$ & $\begin{array}{l}\text { Oliveira (1999), digitalized by Piracicaba- } \\
\text { Capivari-Jundiai Water Agency }\end{array}$ \\
\hline & $\begin{array}{l}\text { Soil map of Minas Gerais } \\
\text { state }\end{array}$ & 1:600.000 & $\begin{array}{l}\text { Embrapa Soils and Federal University of } \\
\text { Viçosa (2010) }\end{array}$ \\
\hline $\begin{array}{l}\text { Meteorological } \\
\text { Gages }\end{array}$ & $\begin{array}{l}\text { Maximum and minimum } \\
\text { air temperature }\left({ }^{\circ} \mathrm{C}\right) \text {, wind } \\
\text { speed }\left(\mathrm{m} \mathrm{s}^{-1}\right) \text {, relative } \\
\text { humidity }(\%) \text {, solar } \\
\text { insolation }(\mathrm{hr})(\text { converted } \\
\text { to solar radiation, } \mathrm{MJ} \mathrm{m}^{-} \\
\left.{ }^{2} \text { day }^{-1}\right) \text {; precipitation }(\mathrm{mm})\end{array}$ & Daily mean & $\begin{array}{l}\text { Brazilian National Institute of Meteorology } \\
\text { (INMET) }\end{array}$ \\
\hline Rain Gages & Precipitation & $\begin{array}{l}\text { Daily sum } \\
(\mathrm{mm})\end{array}$ & $\begin{array}{l}\text { Sao Paulo State Water and Energy Resource } \\
\text { Management Agency (DAEE); Sao Paulo State } \\
\text { Water Utility (SABESP) }\end{array}$ \\
\hline Flow gages & River discharge & $\begin{array}{l}\text { Daily mean } \\
\left(\mathrm{m}^{3} \mathrm{~s}^{-1}\right)\end{array}$ & Sao Paulo State Water Utility (SABESP) \\
\hline Water demand & $\begin{array}{l}\text { Permissions for water } \\
\text { withdrawal and waste } \\
\text { water discharge }\end{array}$ & 2012 & $\begin{array}{l}\text { Sao Paulo State Water and Energy Resource } \\
\text { Management Agency (DAEE) and National } \\
\text { Registration of Water Resources Users } \\
\text { (CNARH) }\end{array}$ \\
\hline
\end{tabular}

The soil texture and organic carbon properties were taken from previous studies (Barreto et al. 2008; Lima et al. 2011; Hickmann et al. 2011), and the hydrologic soil groups (classification of runoff potential for application of "Runoff Curve Number" method, USDA, 1986) from Sartori et al. (2005). The relief is undulating and has the following distribution: 0$12 \%(19.5 \%) ; 12-22 \%$ (20.2\%); 22-30\% (21.7\%); 30-38\% (19.6\%); >38\% (19.0\%). Land use, soil classes and slope classes were used to delineate the Hydrologic Response Units (HRUs), based on $20 \%$ land-use, $10 \%$ soils and $10 \%$ slope thresholds, following the proportionality relation suggested by Jha et al. (2012). The number of land uses defined within a sub-basin are based on the first threshold; the soil classes within each land use are defined based on the second threshold; and the slope classes defined within each soil-land use combination are defined based on the third threshold (Logsdon and Chaubey, 2013). Definition of HRUs was done by a re-sampling process that reapportions the remaining areas of land use/soil/slope classes, until the threshold requirements are met (Winchell et al., 2007).This process resulted in 1375 HRUs, distributed within 85 sub-basins. These sub-basins, in turn, were delineated 
using DEM, pre-defined hydrography (see Table 2.2), and the outlets of interest, while considering similar areas and a reasonable level of basin detail.

Some of the data inputs and parameters were obtained via auxiliary tools: for soil properties we used pedo-transfer functions based on organic carbon, texture and depth of each soil layer and the "Soil-Plant-Air-Water (SPAW) software", both developed by Saxton and Rawls (2006) and Saxton and Willey (2005); for groundwater parameters we used the "Baseflow filter program" (Arnold et al., 1995; Arnold and Allen, 1999); for rainfall spatial distribution we used the "PCP_SWAT- extension of ArcGis 10 software" developed by Dr. Raghavan Srinivasan; and to fill the gaps due to missing weather data (around $0.4 \%$ for precipitation data) we used the "SWAT-WXGEN stochastic weather generator" (Sharpley and Williams, 1990).

\subsubsection{Model calibration and evaluation}

The hydrological response of the basin was simulated for the period 1987 to 2009 (23 years), using the previous year (1986) for model warm up (initialization of model state variables). The hydrological model was calibrated for the most undisturbed possible condition (Van Loon and Van Lanen, 2013) using observed time series from Jan $1^{\text {st }} 1987$ (Julian day 1) to Dec $31^{\text {st }} 1995$ (Julian day 365) and without including any water abstractions. The evaluation period was selected to be Jan $1^{\text {st }} 1996$ (Julian day 1) to Dec $31^{\text {st }} 2001$ (Julian day 365). Based on the automated sensitivity analysis tool provided by the SWATCUP software (Abbaspour, 2012) and suggestions from the SWAT Calibration Techniques Manual (Arnold et al., 2011) we selected eight (8) hydrological parameters for manual, and thereafter automatic, calibration using Sequential Uncertainty Fitting (SUFI-2), which is a local optimization algorithm (Abbaspour et al., 2004) also available at the SWATCUP software site. Another five (5) parameters were also changed from their default values. During calibration, most of the parameters were set to be constant values across the entire basin. However, certain parameters (e.g. CN2, Canmx, OV_N, SOL_K, SOL_AWC) were adjusted to correspond to observed soil and/or land use classes (Glavan et al., 2013) (Table 2.3). A similar set of parameters was used in previous studies involving calibration of the SWAT model to reproduce observed streamflow (White and Chaubey, 2005; Zhang et al., 2009). 
Table 2.3 - Streamflow related SWAT parameter values that were calibrated or changed from their default values

\begin{tabular}{|c|c|c|c|c|}
\hline $\begin{array}{l}\text { Main } \\
\text { parameters } \\
\text { function }\end{array}$ & Description & $\begin{array}{l}\text { SWAT } \\
\text { parameter }\end{array}$ & Default value & $\begin{array}{l}\text { Calibrated/ } \\
\text { changed } \\
\text { value }\end{array}$ \\
\hline \multirow[t]{5}{*}{$\begin{array}{l}\text { Surface } \\
\text { water } \\
\text { response }\end{array}$} & $\begin{array}{l}\text { 1. Soil evaporation compensation factor } \\
\text { (capacity of the model to extract the } \\
\text { evaporative demand from soil layers, by } \\
\text { inverse relationship) }\end{array}$ & ESCO & 0.95 & 0.75 \\
\hline & $\begin{array}{l}\text { 2. SCS runoff Curve Number for average } \\
\text { moisture condition }\end{array}$ & $\mathrm{CN} 2$ & $\begin{array}{l}\text { Varies by } \\
\text { vegetation and } \\
\text { hydrologic soil } \\
\text { group }\end{array}$ & $\Delta+2 \%$ \\
\hline & $\begin{array}{l}\text { 3. Maximum canopy index: maximum amount } \\
\text { of water that can be trapped in the } \\
\text { vegetation canopy }(\mathrm{mm})^{*}\end{array}$ & CANMX & 0 & $\begin{array}{l}\text { Varies by } \\
\text { vegetation }\end{array}$ \\
\hline & 4. Manning's value for overland flow* & OV_N & 0.15 & $\begin{array}{l}\text { Varies by } \\
\text { vegetation }\end{array}$ \\
\hline & 5. Available soil water capacity $\left(\mathrm{mm} \mathrm{mm}^{-1}\right)^{*}$ & SOL_AWC & \multicolumn{2}{|c|}{ Varies by soil } \\
\hline \multirow[t]{2}{*}{$\begin{array}{l}\text { Basin } \\
\text { response }\end{array}$} & $\begin{array}{l}\text { 6. Surface runoff lag coefficient: factor to lag } \\
\text { a portion of the surface runoff release to the } \\
\text { main channel (days) }\end{array}$ & SURLAG & 4 & 0.05 \\
\hline & 7. Manning coeficient for channel* & CH_N2 & 0.015 & $\begin{array}{l}0.025 \\
\text { (Natural } \\
\text { streams) }\end{array}$ \\
\hline \multirow{6}{*}{$\begin{array}{l}\text { Groundwater } \\
\text { response }\end{array}$} & 8. Soil hydraulic conductivity $\left(\mathrm{mm} \mathrm{h}^{-1}\right)^{*}$ & SOL_K & \multicolumn{2}{|c|}{ Varies by soil } \\
\hline & $\begin{array}{l}\text { 9. Delay time for aquifer recharge (days): time } \\
\text { lag between the time that water exits the } \\
\text { soil profile and enters the shallow aquifer } \\
\text { (days) }\end{array}$ & GW_DELAY & 31 & 116.0 \\
\hline & $\begin{array}{l}\text { 10. Groundwater "revap" coefficient: } \\
\text { regulates the movement of water from the } \\
\text { shallow aquifer to the root zone in } \\
\text { response to moisture deficit }\end{array}$ & GW_REVAP & 0.02 & 0.03 \\
\hline & $\begin{array}{l}\text { 11. Baseflow recession constant: response } \\
\text { index of groundwater flow (into the main } \\
\text { channel) to changes in shallow aquifer } \\
\text { recharge (days)* }\end{array}$ & ALPHA_BF & 0.048 & 0.0283 \\
\hline & $\begin{array}{l}\text { 12. Fraction of water percolation to deep } \\
\text { aquifer (fraction) }\end{array}$ & RCHRG_DP & 0.05 & 0.03 \\
\hline & $\begin{array}{l}\text { 13. Threshold water level in shallow aquifer } \\
\text { for base flow (mm) }\end{array}$ & GWQMN & 0 & 1000 \\
\hline
\end{tabular}

*Parameter values changed from their default values

The surface runoff process was simulated by the "U.S. NRCS - Curve Number (CN)" method using daily $\mathrm{CN}$ value as function of antecedent soil moisture condition (traditional method) and slope adjustment (using the equation of Williams, 1995) (Neitsch et al., 2011). Evapotranspiration process, in turn, was estimated using the Penman-Monteith equation (Monteith, 1965).

The calibration and evaluation period results were analyzed at daily time scale (at which the SWAT model was run), using several graphical and statistical measures, including 
the coefficient of determination $\left(\mathrm{R}^{2}\right)$, the ratio of the root mean square error to the standard deviation of measured data (RSR) (Legates and McCabe, 1999), the Nash-Sutcliffe Efficiency coefficient (NSE) (Nash and Sutcliffe, 1970), the NSE computed using the logarithm of observed and simulated discharges (Q) to emphasize low flows (Seibert, 1999; Krause et al., 2005; Van Loon and Van Lanen, 2013), the Percent Bias statistic (PBIAS) (Gupta et al., 1999), and the Mean Squared Error (MSE) and its components (Gupta et al., 2009) (Figure 2.3). Progressive parameter adjustments were made to improve the match between model simulations and observed streamflow, using the performance criteria thresholds recommended by Moriasi et al. (2007); i.e., NSE $>0.5$; RSR $\leq 0.7$; PBIAS $< \pm 25$; $\mathrm{R}^{2}>0.5$, in addition to seeking a minimum value for MSE. The resulting evaluation measure values obtained are in line with other SWAT studies cited by Douglas-Mankin et al. (2010). The MSE value (and its component decomposition; Figure 2.3) shows the overall performance of the calibrated model in terms of three statistics, associated with reproduction of different aspects of the streamflow hydrograph: linear correlation (related to reproduction of hydrograph timing and shape), percent bias (related to water balance), and percent variability error (related to slope of the flow duration curve) (Gupta et al., 2009).

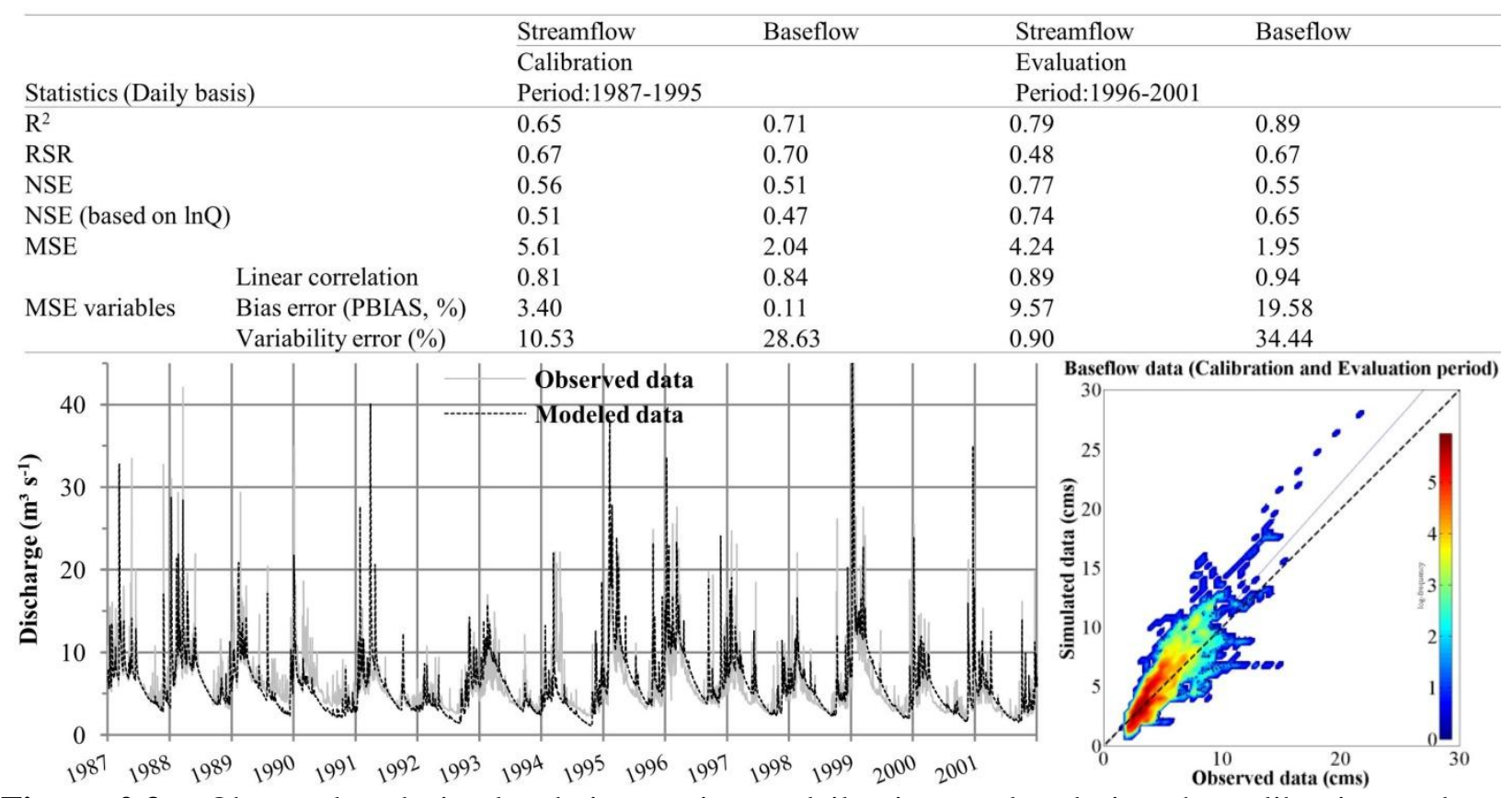

Figure 2.3 - Observed and simulated time series at daily time scales during the calibration and evaluation periods

The simulated and observed hydrographs were separated into two components (baseflow and surface-runoff) using the USGS HYSEP program, developed by Sloto and Crouse (1996) (see Matlab code in DeGasperi and Burkey, 2012). These components were 
generated by a filtering methodology, called Local-minimum Method, in which the points of local minima are connected by comparing the slope of hydrograph (Sloto and Crouse, 1996). The evaluation statistics and correlation graph of baseflow modeling is also showed in Figure 2.3 .

In addition to an evaluation of how well the model outputs fit the field observations, the model was also assessed for mass balance/continuity, to analyze how well it represents the set of physical processes in the field (fit-to-reality) (van Griensven et al., 2012).

\subsubsection{Mass balance in SWAT model}

The general water balance equation in the SWAT model may be expressed by equation 1 (van Griensven et al., 2012), where each of the components can be associated to blue/green water fluxes or storage. For long-term mass balance, if we expect no trend in storage, then flows and losses become equal to rainfall (van Griensven et al., 2012).

Rainfall $=$ Evapotranspiration + Water Yield $+\Delta($ Soil Storage $)+\Delta($ Groundwater Storage $)+$ Losses

"Blue water" is represented by "Water Yield" (SWAT output WYLD), which is the total amount of water leaving the HRU and entering main channel, and by "Groundwater Storage" (difference between the total amount of water recharge to shallow and deep aquifers (SWAT output GW_RCHG) and the amount of shallow aquifer water that contributes to the main channel (SWAT output GW_Q) during the time step. "Green Water" is represented by the "Actual Evapotranspiration" (SWAT output ET), and by the Soil Water Content (SWAT output SW), as also suggested by Schuol et al. (2008).

Here, the use of Blue and Green water flows/storage for human activities was analyzed in the context of average hydro-climatic conditions during the simulation period (1987-2009), and water scarcity and vulnerability indicators were then computed to be integrated into the water security analysis.

\subsection{Assessment of Green Water Security}

Scarcity and vulnerability indicators were used for evaluating green water security in the study basin. The Green Water Scarcity indicator (GW-Scarcity) was computed for agricultural activities such as pasture, woody crops and annual crops, as the ratio between the Potential Green Water Footprint (Potential GW-Footprint), estimated by the sum of 
"maximum transpiration", and "soil water evaporation" amounts, and Green Water Provision (GW-Provision), represented by Soil Water content (SW) at the beginning of the period. The SW variable represents the amount of moisture available for use by plants and soil for evapotranspiration, which is calculated as the total soil moisture in the root zone minus the wilting point (DeLiberty and Legates, 2003; Srinivasan, R., personal communication 2014). Note that the Potential GW-Footprint estimate is influenced by climatology and vegetation properties, not taking into account the balance with SW amounts, i.e. they are independent variables, which were obtained by a modification of SWAT model code.

The results were obtained at the HRU level from SWAT model outputs, and then used to compute GW-Scarcity for each sub-basin studied (Equation 2). The green water scarcity indicator represents how close the average water use is to the physical threshold of water availability.

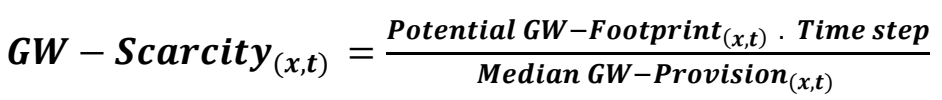

where $G W$-Scarcity $(x, t)$ indicates the level of green water use for human activities at a specific location (sub-basin) $(x)$ and time of the year $(t)$, Potential GW-Footprint $(x, t)$ represents the potential green water consumption $\left(\mathrm{LT}^{-1}\right), G W$-Provision $(x, t)$ is the corresponding median (or $50^{\text {th }}$ percentile) of green water available for use (L) in the beginning of the period, and the time step refers to temporal resolution of the case study, e.g. month (T).

Based on Padowski and Jawitz's (2012) concepts, the Green Water Vulnerability indicator ( $G W$-Vulnerability) was expressed as the susceptibility of agriculture water consumption under low soil water content, or drought-like conditions. It was defined using the historical low green water provision and the potential green water footprint for the study basin (Equation 3):

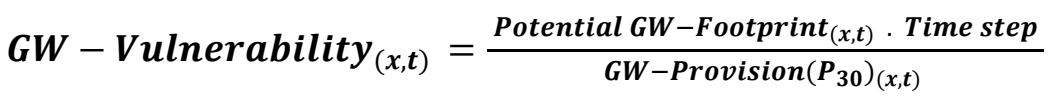

where $G W$-Provision $\left(P_{30}\right)_{(x, t)}$ is the historical low volume of soil water content at a specific location (sub-basin) (x) and time of the year (t), that is exceeded $70 \%$ of the time, represented by the $30^{\text {th }}$ percentile of the records $(\mathrm{L})$.

This indicator joins supply- and demand- driven variables of water vulnerability (Sullivan, 2011) and defines the limit between "vulnerable", and "secure". The locations and time period facing threats from source variability are those with $G W$-vulnerability $>1$ (hotspots), which have low green water provision that drops below the water required to 
sustain the actual crop water consumption. So, hotspots (times and places in which water conflicts are more likely to occur) are identified by high values of $G W$-vulnerability and $G W$ scarcity.

\subsection{Assessment of Blue Water Security}

Similarly, blue water security was evaluated using scarcity and vulnerability indicators, in terms of BW-Footprint or water abstraction permits, respectively. Such indicators contrast water use against probabilistic levels of water provision, which are based on the satisfaction of $100 \%$ of environmental demand. We assumed that the water use term involves the concepts of both withdrawal (equal to demand) and consumption (withdrawal minus return flow) (USEPA, 1995).

\subsubsection{Blue Water Footprint}

One of the institutions that contributes to management of the study basin is the Sao Paulo State Water and Energy Resource Management Agency (DAEE), which controls the access to water rights for consumptive and non-consumptive uses within the river basin, in accordance with the current basin plan priorities and water uses allowed for the river segment (PCJ, 2011). The current BW-Footprint refers to blue water appropriation, or consumptive water use, which was defined by the difference between the water permits values for withdrawal and wastewater discharge for reference year 2012. The spatial distribution of water users within the river basin is depicted in Figure 2.2, while the quantitative distribution of these water permits is presented in Figure 2.4, in accordance with water use sector and subbasin studied.
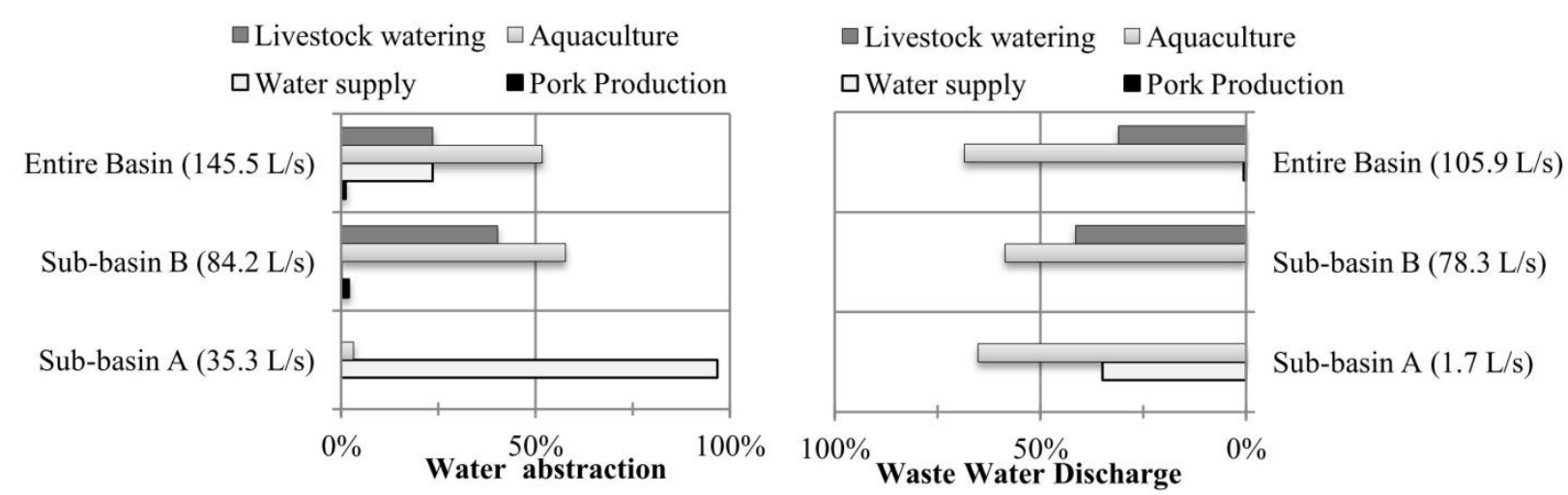

Figure 2.4 - Distribution of water permits for abstractions and wastewater discharge for each water use sector and sub-basin studied 
In addition to considering the current $B W$-footprint and -abstractions, we also took into account the critical values defined by Water Resources State Plan reported in the Law 9034/1994 (Sao Paulo State, 1994), which are computed as 50\% (fifty per cent) of the reference streamflow adopted (i.e. $\mathbf{Q}_{7,10}$, see definition below). Here, we considered the same critical values for abstractions and BW-Footprint at sub-basin A $\left(0.30 \mathrm{~m}^{3} \mathrm{~s}^{-1}\right)$, sub-basin B: $\left(0.32 \mathrm{~m}^{3} \mathrm{~s}^{-1}\right)$; and entire basin $\left(0.75 \mathrm{~m}^{3} \mathrm{~s}^{-1}\right)$.

\subsubsection{Blue Water provision based on Environmental Flow Requirements (EFR)}

Estimates of Blue Water Provision (BW-Provision) for human activities were developed, by taking into account the water availability (in the rivers) for consumptive water use (Hoekstra et al., 2011) (Equation 4).

BW-Provision $_{(i, x, t)}=Q_{(x, t)}-$ EFR $_{(i, x, t)}$

where the $B W$-Provision $(x, t)$ is computed for a specific location (sub-basin) (x) and time of the year $(t)\left(\mathrm{L}^{3} \mathrm{~T}^{-1}\right), Q_{(x, t)}$ is the corresponding daily streamflow in the river $\left(\mathrm{L}^{3} \mathrm{~T}^{-1}\right)$, and $\mathrm{EFR}_{(i, x, t)}$ is the corresponding fraction of river discharge maintained to meet Environment Flow Requirements for specific month of the year and hydrological-based method (indexed by i) $\left(\mathrm{L}^{3} \mathrm{~T}^{-1}\right)$.

The EFR values were defined using three hydrological-based methodologies at the three control points in the study basin corresponding to the basin and sub-basins outlets. River discharge values provided by the calibrated SWAT model were used to simulate the naturalized situation (as closely as possible) for EFR accounting during the entire simulation period (Van Loon and Van Lanen, 2013). These three methodologies incorporate four methods, as can be seen below:

i) Low Streamflow method (7 days and 10-years): Currently the water rights are released by the local authority, after considering the conservation requirement to maintain a minimum flow into the rivers of Cachoeira river basin. Such EFR has no intra-annual flow variability and is defined by the statistical method of 7-day, 10-year, low-flow $\left(\mathrm{Q}_{7,10}\right)$ (Sao Paulo State, 1994; Benetti et al., 2003; PCJ, 2011). The $\mathrm{Q}_{7,10}$ value is the average annual 7-day minimum flow that is expected to be exceeded on average in 9 out of every 10 years, which is equivalent to the tenth percentile of the distribution of 7-day annual minimum streamflows (Reily and Kroll, 2003). The frequency of extreme low streamflow series was adjusted to 
lognormal probability distribution (Chow et al., 1988), while ensuring that the acceptable standard errors were less than 0.10 for all sub-basins outlets studied.

ii) Presumptive standard method: It was proposed by Richer et al. (2012) and has been used in water footprint studies such as Hoekstra et al. (2011, 2012) and Zeng et al. (2012). The presumptive standard is intended for application only where detailed scientific assessments of environmental flow needs cannot be undertaken in the near term; it assumes (for planning purposes) that $20 \%$ of the natural monthly mean flow can be allocated for consumptive use (Richer et al., 2012) (Equation 5):

$\operatorname{EFR}_{\text {presumptive }(x, t)}=0.8 \cdot$ Qmean $_{(x, t)}$

where $\operatorname{Qmean}_{(x, t)}$ is long-term monthly mean streamflow in the river $\left(\mathrm{L}^{3} \mathrm{~T}^{-1}\right)$.

iii) Adapted Smakhtin-methodology: The Smakhtin EFR methodology focuses on estimating ecologically acceptable proportions of baseflow and quickflow, which could be allocated for freshwater ecosystem maintenance, and is computed as the sum of the Low and High Flow Requirements (LFR and HFR, $\mathrm{L}^{3} \mathrm{~T}^{-1}$ ) (Smakhtin et al., 2004). The LFR indicates the minimum flow requirement for fish and other aquatic species throughout the year, while the HFR is important for river channel maintenance, wetland flooding, and riparian vegetation (Smakhtin et al., 2004). Both LFR and HFR change with flow variability and the goals of environmental water management. We adapted the Smakhtin methodology from annual to monthly EFR estimation (Equation 6).

$E F R_{(\text {moderate; }}$ or fair) $(x, t)=\operatorname{LFR}_{(x, t)}+\operatorname{HFR}_{(x, t)}$

The LFR is defined by a selecting a specific percentile point value from the Flow Duration Curve (FDC), constructed using daily flow records. The percentile point was chosen in accordance with Environment Management Class (EMC), which means the "desired future state" of the river basin (Smakhtin et al., 2004; Smakhtin and Eriyama, 2008): for Moderate conservation (slightly or moderately modified basin, with minor water supply schemes or irrigation development) the LFR is Q75\%; for Fair conservation (considerably modified basin, with multiple disturbances associated with socio-economic development) the LFR is Q90\%.

The HFR component was defined in accordance with the type of flow regime proposed by Hughes \& Hannart (2003) and Smakhtin et al. (2004), which relates long-term monthly mean streamflow (Qmean) and monthly LFR values: for basins with highly variable flow, where LFR is less than 10 percent of the Qmean, the HFR is set to 20 percent of the Qmean; for rivers where LFR ranges from 10 to 20 percent and from 20 to 30 percent of the 
Qmean, the HFR levels are set at 15 percent and 7 percent of the Qmean, respectively; for rivers with stable flow, where LFR is higher than 30 percent of the Qmean, the HFR is set to zero.

We applied two EMC conditions (moderate, and fair conservation) for evaluation of EFR values in the study basin. The LFR values of 75-, and 90-percent exceedance probability resulted in HFR equal to zero, because such LFR values are greater than $30 \%$ of Qmean for all control points we considered (outlets of sub-basin A, sub-basin B, and entire basin). Then, for two EMC conditions, the EFRs in such perennial rivers are represented only by the LFR portion.

\subsubsection{Freshwater Provision Indicator}

The effects of EFR methods were indicated by the quantitative component of Freshwater Provision Indicator $\left(\right.$ FWPI $\left._{\text {quantitative }}\right)$, proposed by Logsdon and Chaubey (2013) (Equation 7). This considers the natural reasons (drought) for risk of violating EFR levels in terms of the frequency of monthly mean river discharge being less than EFR. The FWPI $_{\text {quantitative }}$ will be equal to one if EFR are met throughout the time period, and otherwise will be less than one (Logsdon and Chaubey, 2013).

$F W P I_{\text {quantitative }(i, x, t)}=\frac{\operatorname{Qmean}_{(x, t)} / E F R_{(i, x, t)}}{\left(\operatorname{Qmean}_{(x, t)} / E F R_{(i, x, t)}\right)+\left(q e_{t} / n_{t}\right)}$

where $\mathrm{FWPI}_{\text {quantitative(x,t) }}$ is computed for a specific location (sub-basin) (x) and month (t) of the year, $q n e_{t}$ is the number of months $(\mathrm{T})$ when monthly mean river discharge is less than the EFR during the period studied, and $n_{t}$ is the total number of months (length of the period studied, T).

\subsubsection{Blue Water Scarcity}

The BW-Footprint was compared with median BW-Provision over the simulation period (1987-2009), which reflects the variability of climate during the 23 year study period, then the Blue Water Scarcity (BW-Scarcity) indicator was estimated (Equation 8): 
$B W-\operatorname{Scarcity}_{(i, x, t)}=B W-$ Footprint $_{(x, t)} /$ Median BW $-\operatorname{Provision}_{(i, x, t)}$

where $B W$-Footprint $(x, t)$ represents the consumptive water use for human activities at a specific location (sub-basin) and time (month) of the year, and Median BW-Provision $(x, t)$ takes into account the $50^{\text {th }}$ percentile of $B W$-Provision $(x, t)$ for each EFR method (indexed by i) $\left(\mathrm{L}^{3} \mathrm{~T}^{-}\right.$ $\left.{ }^{1}\right)$ (Equation 4).

\subsubsection{Blue Water Vulnerability}

Blue Water Vulnerability ( $B W$-Vulnerability) is expressed as the susceptibility of water withdrawal for human activities under low-flow, or drought like, conditions (Padowski and Jawitz, 2012). Here, it was defined using the historical low-flow conditions and the blue water abstraction for the study basin (Equation 9) as:

$B W-$ Vulnerability $_{(i, x, t)}=B W-$ Abstraction $_{(x, t)} / B W-\operatorname{Provision}\left(P_{30}\right)_{(i, x, t)}$

where $B W$-Abstraction $(x, t)$ is the corresponding sum of water permits for abstraction within the basin $\left(\mathrm{L}^{3} \mathrm{~T}^{-1}\right)$, and $B W$-Provision $\left(P_{25}\right)_{(i, x, t)}$ is the low-flow volume of $B W$-Provision (Equation 4) at $x$ and $t$ for each EFR method (indexed by i) that is exceeded $70 \%$ of the time, represented by the $30^{\text {th }}$ percentile of the records $\left(\mathrm{L}^{3} \mathrm{~T}^{-1}\right)$

Similar to the concept of $G W$-Vulnerability, the vulnerable locations and time period are those with $B W$-Vulnerability $>1$ (hotspot), which have low water provision flows that drop below the minimum water required to sustain human demand (Padowski and Jawitz, 2012). In the same way, high BW-vulnerability and -scarcity values area useful to identify hotspots (time and places in which water conflicts are more likely to occur).

\section{Results and Discussion}

\subsection{Annual balance of blue and green}

Annual average values for the various hydrological components, obtained by aggregating simulated results over the period 1987-2009, were used to quantify blue and 
green water general balance and examine spatial patterns within the basin and its sub-basins (Table 2.4).

Table 2.4 - Annual average of green and blue water flows, variation of storage and footprint components from aggregation of results for Cachoeira river basin at the current LULC

\begin{tabular}{|c|c|c|c|c|c|c|c|}
\hline \multirow[b]{3}{*}{$\begin{array}{l}\text { Spatial } \\
\text { Scale }\end{array}$} & \multirow[b]{2}{*}{ Precipitation } & \multicolumn{2}{|c|}{ Blue water } & \multicolumn{2}{|c|}{ Green Water } & \multirow[b]{2}{*}{$\begin{array}{l}\text { Blue } \\
\text { Water } \\
\text { Footprint }\end{array}$} & \multirow[b]{2}{*}{$\begin{array}{l}\text { Green Water } \\
\text { Footprint }\end{array}$} \\
\hline & & $\begin{array}{l}\text { Surface } \\
\text { water }\end{array}$ & $\begin{array}{l}\Delta \text { (Groundwater } \\
\text { Storage) }\end{array}$ & $\begin{array}{l}\text { Green water Flow } \\
\text { (Actual } \\
\text { evapotranspiration) }\end{array}$ & $\begin{array}{l}\Delta(\text { Green } \\
\text { water } \\
\text { storage })\end{array}$ & & \\
\hline & $\left(\mathrm{mm}\right.$ year $\left.^{-1}\right)$ & $\begin{array}{l}\left(\mathrm{mm} \text { year }^{-1}\right) \\
\text { (Fraction of } \\
\text { Rainfall) }\end{array}$ & $\begin{array}{l}\left(\mathrm{mm} \text { year }^{-1}\right) \\
\text { (Fraction of } \\
\text { Rainfall) }\end{array}$ & $\begin{array}{l}\left(\mathrm{mm} \text { year }^{-1}\right) \\
\text { (Fraction of } \\
\text { Rainfall) }\end{array}$ & $\begin{array}{l}(\mathrm{mm} \\
\left.\text { year }^{-1}\right) \\
(\text { Fraction } \\
\text { of } \\
\text { Rainfall) }\end{array}$ & $\begin{array}{l}\left(\mathrm{hm}^{3}\right. \\
\left.\text { year }^{-1}\right)\end{array}$ & $\begin{array}{l}\left(\mathrm{hm}^{3} \text { year }^{-1}\right) \\
(\text { agricultural } \\
\left.\text { land, } \mathrm{km}^{2}\right)\end{array}$ \\
\hline \multirow{2}{*}{$\begin{array}{l}\text { Sub- } \\
\text { basin A }\end{array}$} & \multirow[t]{2}{*}{1705.6} & 659.7 & 16.5 & 1022.0 & 7.4 & \multirow[t]{2}{*}{1.1} & \multirow{2}{*}{$\begin{array}{l}106.8 \\
\left(112.9 \mathrm{~km}^{2}\right)\end{array}$} \\
\hline & & $38.7 \%$ & $1.0 \%$ & $59.9 \%$ & $0.4 \%$ & & \\
\hline \multirow{2}{*}{$\begin{array}{l}\text { Sub- } \\
\text { basin B }\end{array}$} & \multirow[t]{2}{*}{1868.3} & 732.9 & 17.2 & 1110.1 & 8.0 & \multirow[t]{2}{*}{0.2 . } & \multirow{2}{*}{$\begin{array}{l}71.7 \\
\left(72.8 \mathrm{~km}^{2}\right)\end{array}$} \\
\hline & & $39.2 \%$ & $0.9 \%$ & $59.4 \%$ & $0.4 \%$ & & \\
\hline \multirow{2}{*}{$\begin{array}{l}\text { Entire } \\
\text { basin }\end{array}$} & \multirow[t]{2}{*}{1751.0} & 686.9 & 16.5 & 1040.1 & 7.4 & \multirow[t]{2}{*}{1.3} & \multirow{2}{*}{$\begin{array}{l}214.4 \\
\left(225.6 \mathrm{~km}^{2}\right)\end{array}$} \\
\hline & & $39.2 \%$ & $0.9 \%$ & $59.4 \%$ & $0.4 \%$ & & \\
\hline
\end{tabular}

Our results indicate that the proportionality relation between blue and green water flow fractions for our study area are similar across all the scales studied. Such values can be considered reasonable for a humid tropical region, taking into account that Falkenmark and Rockstrom (2010) reported the global average of 35\% for BW flow and 65\% for GW flow, and $94.3 \%$ (GW flow) and 5.7\% (BW flow) for Kenya (arid and semiarid climate), Glavan et al. (2013) found 52\% for GW flow at Western Slovenia (sub-Mediterranean climate, rainfall:1446 mm/y), and Schuol et al. (2008) obtained 76-87\% for GW flow at Burkina Faso (Western Africa, semi-arid climate, rainfall:736 mm/y), and 46-47\% for GW flow at SierraLeone (Western Africa, monsoon climate, rainfall: 2219 mm/y).

From Table 2.4, note that sub-basin A has the highest GW-Footprint due to it having significant amounts of agricultural lands, mostly pasture areas for livestock. Conversely, subbasin $\mathrm{B}$ has the lowest GW-Footprint values due to its having a larger amount of native forest land (or less amount of agricultural lands).

\subsection{Temporal and spatial assessment of Green Water Security}

GW-Scarcity is evaluated by comparing the Potential GW-Footprint to the availability of Green water as median of soil moisture. Our results show that this indicator is at less than $50 \%$ throughout the year at all of the scales studied (Figure 2.5). For all of the sub-basins, the 
levels of GW-Footprint and GW-Scarcity tend to be lowest during the winter season (June August). On the other hand, higher values are seen during the summer and part of the spring (October - March) due to significant crop growth during this period. The sub-basin A had the highest frequency of $G W$-Scarcity values between $40 \%$ and $50 \%$. Soil moisture ranges agree well with literature estimates for 'Available Water Content' in similar soil textures (175-200 $\mathrm{mm} / \mathrm{m}$ of clay soils; $100-175 \mathrm{~mm} / \mathrm{m}$ of loam soils; $25-100 \mathrm{~mm} / \mathrm{m}$ of sandy soils) (FAO, 1985).

To evaluate GW-vulnerability, we consider the probability of low water availability $\left(30^{\text {th }}\right.$-percentile). Similarly to the scarcity indicator, $G W$-Vulnerability shows more secure levels during drought periods (winter season) (Figure 2.5). The crop growth component of SWAT model, called EPIC - Erosion Productivity Impact Calculator (Sharpley and Williams, 1990), assumes that perennial plants maintain their root systems throughout the year, becoming dormant in the winter months, and resume their growth when the average daily temperature exceeds the minimum temperature required (Neitsch et al., 2011). So, the lower crop water demand during the winter months results in lower $G W$-Scarcity and $G W-$ Vulnerability.
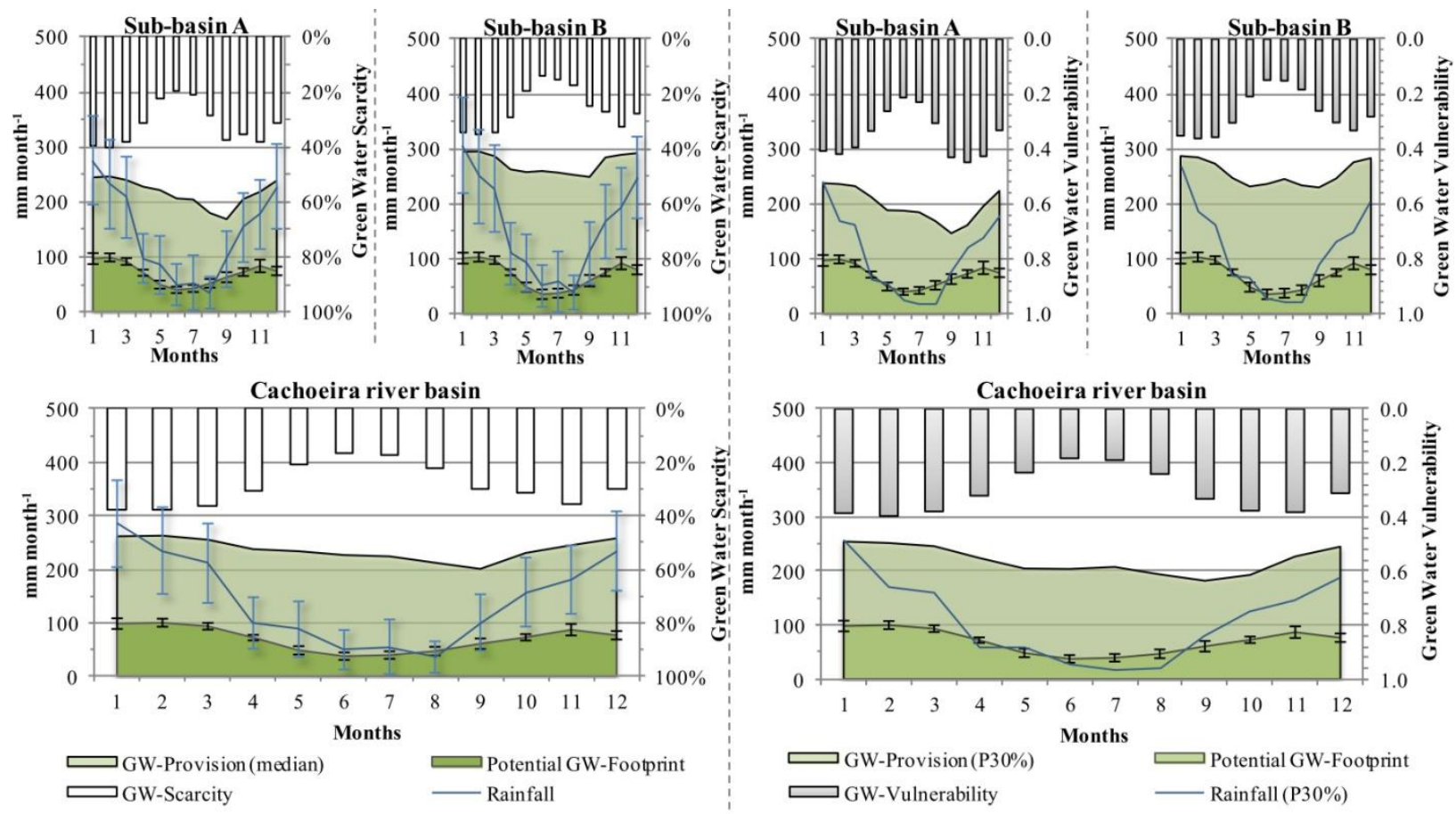

Figure 2.5 - GW-Scarcity (on the left) and -Vulnerability (on the right) indicators for the Cachoeira river basin and each sub-basin studied. On the left it showed graphs with monthly means of rainfall $(\mathrm{mm}), G W$-Footprint $\left(\mathrm{mm}\right.$ month $\left.^{-1}\right)$, and -Provision $(\mathrm{mm})$, where each standard deviation bar was obtained using the time series of each specific month. On the right it presented graphs with the monthly mean of $G W$-Footprint $\left(\mathrm{mm}\right.$ month $\left.^{-1}\right), 30^{\text {th }}$ percentile of monthly $G W$-provision $(\mathrm{mm})$ and rainfall $(\mathrm{mm})$, where the $G W$-vulnerability values above 1 correspond to vulnerable conditions. 


\subsection{Temporal and spatial assessment of Blue water security}

We analyze temporal patterns of BW-Provision (streamflow minus EFR) by considering several types of monthly flow levels for aquatic ecosystem needs (EFRs). Each of the EFR methods provides a different limit on the blue water provision for human use (Wilby et al., 2011). The hydrological behavior of the basin during the year is demonstrated by the monthly FDCs showed in Figure 2.6A, where the EFR alternatives, mean and median streamflow are also plotted. The $Q_{7,10}$ at basin outlet compromises $27 \% \pm 11 \%$ (mean \pm standard deviation) of monthly mean streamflow at basin outlet, while the EFR for fair, and moderate conservation goals (from adapted Smakhtin methodology) rise this value to $55 \% \pm 6 \%$, $69 \% \pm 6 \%$, respectively. The "presumptive standard" method (EFR presumptive $)$ is calculated using the $80 \%$ fraction of long-term mean monthly flows, it is therefore the most restrictive and has the highest conservation goals. The adapted Smakhtin method for considerably modified basins $\left(E F R_{\text {fair }}\right)$ obtains intermediate values between $Q_{7,10}$ and $E F R_{\text {moderate }}$. The minimum flow $Q_{7,10}$ method is the least restrictive, particularly during the summer season. Overall, the differences between the probabilistic water provision levels (50th- and 30th-percentiles) obtained using the different EFR methods tend to decrease during the dry seasons (specially in winter, June-September), indicating that the sensitivity of water provisioning to choice of EFR method is larger during the wet season (Figures 2.6B and 2.6C); this is largely due to the lower variability of streamflow during the dry season, which is indicated by FDCs of April to September. 

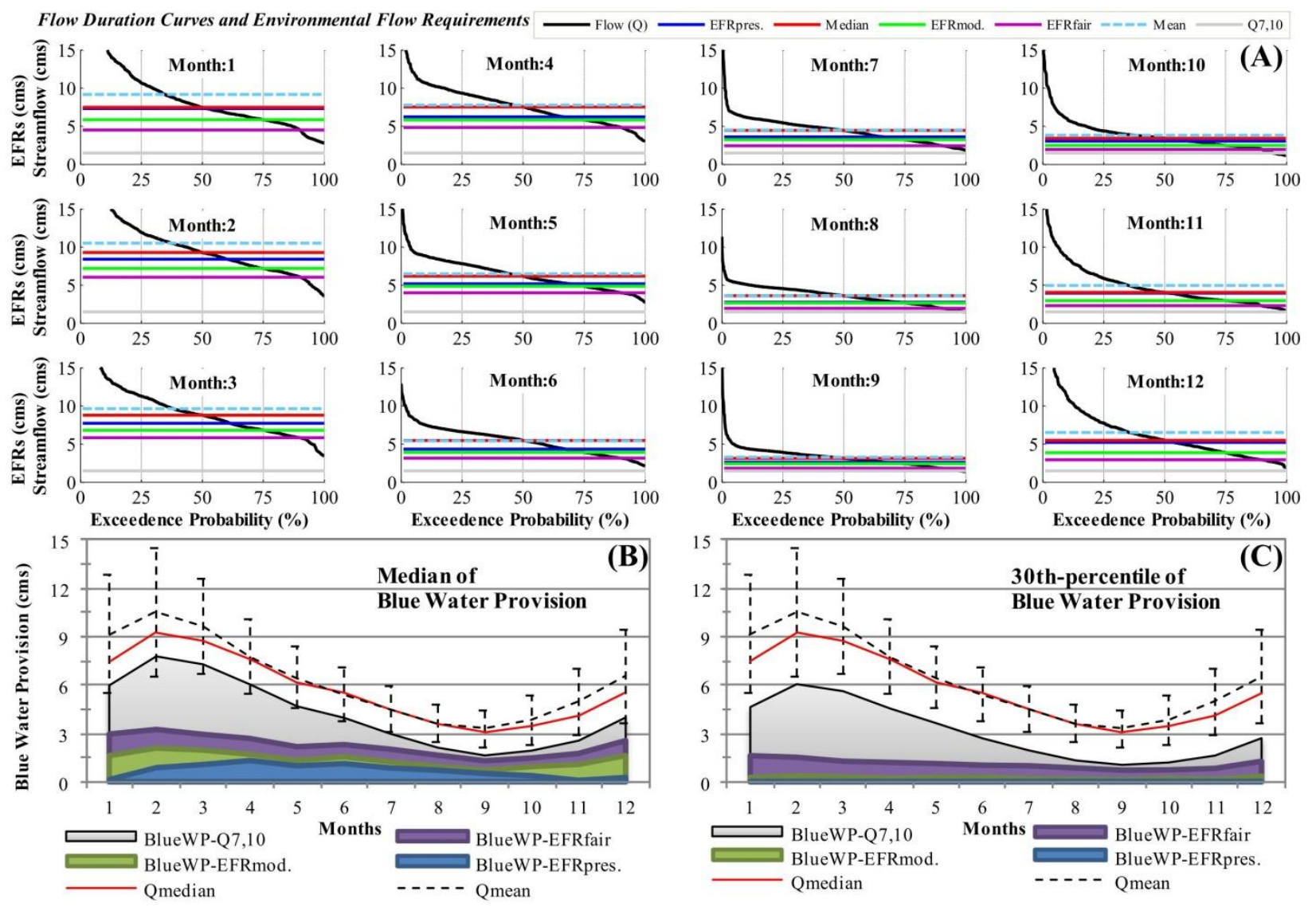

Figure 2.6 - Flow duration curves and EFR estimates for each month of the year (above); and median and 30th-percentile of Blue Water Provision considering different EFR methods at the basin studied (bottom left and bottom right, respectively). The standard deviation bars were obtained using the values set of each specific month. Legend: BW-Provision- $\mathrm{Q}_{7,10}$ (from Low Streamflow method); BW-

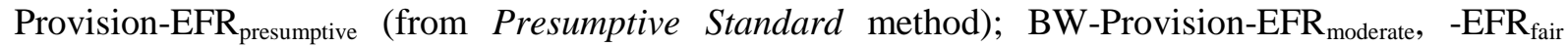
(from adapted Smakhtin-metodology for EMCs referring to moderate and fair conservation goals, respectively); Qmean (long-term mean monthly values for streamflow discharge); Qmedian (long-term median monthly values for streamflow discharge).

We analyzed the impacts of EFR methods on blue water availability by estimating $F W P I_{\text {quantitative }}$ for each month and EFR method, which considers the frequency of river discharge being less than EFR. The annual average of $F W P I_{\text {quantitative }}$ and standard deviation in accordance with the EFR method for the entire basin at the outlet were: $0.79 \pm 0.02$ (EFR $\left.R_{\text {presumptive }}\right) ; 0.88 \pm 0.04$ (EFR $\left.R_{\text {moderate }}\right) ; 0.96 \pm 0.01\left(E F R_{\text {fair }}\right)$; and $1.00 \pm 0.00\left(Q_{7,10}\right)$. Longsdon and Chaubey (2013) reported FWPI values between 0.50 and 0.70, using the Tennant method (30\% of long-term average flow) for EFR estimation, and an additional qualitative component.

The $F W P I_{\text {quantitative }}$ based on $\mathrm{Q}_{7,10}$ did not provide any significant violation during the 23-year period analyzed, while the other methods provided a higher frequency of natural EFR violation. Such indicators allow us to compare the EFR methods among themselves establishing a restrictiveness scale (crescent): $Q_{7,10} \rightarrow E F R_{\text {fair }} \rightarrow E F R_{\text {moderate }} \rightarrow E F R_{\text {presumptive }}$ 
So, the low values of $F W P I_{\text {quantitative }}$ can also be useful for inferring natural reasons (drought) for high levels of risk of violating the EFR (by inverse relationship).

Next, the $B W$-Scarcity estimates were evaluated in the context of each of the different EFR methods (Figure 2.7). Overall, BW-Scarcity, based on current BW-Footprint, is classified as being in the range of 0 to $20 \%$ for most of the EFR methods, with some exceptions due to the extremely low values of $B W$-Provision obtained using the EFR $R_{\text {presumptive }}$ method, as was identified by Figure 2.6 and suggested by restrictiveness of $F W P I_{\text {quantitative }}$. Sub-basin A stands out as having the highest levels of current $B W$-Scarcity, which, in line with the green water assessment (Figure 2.5), reflects the significant degree of development of the region. The lower flows during the dry (winter) season also lead to higher water scarcity classifications, contrasting with the green values (GW-Scarcity) which are lower during the same season.
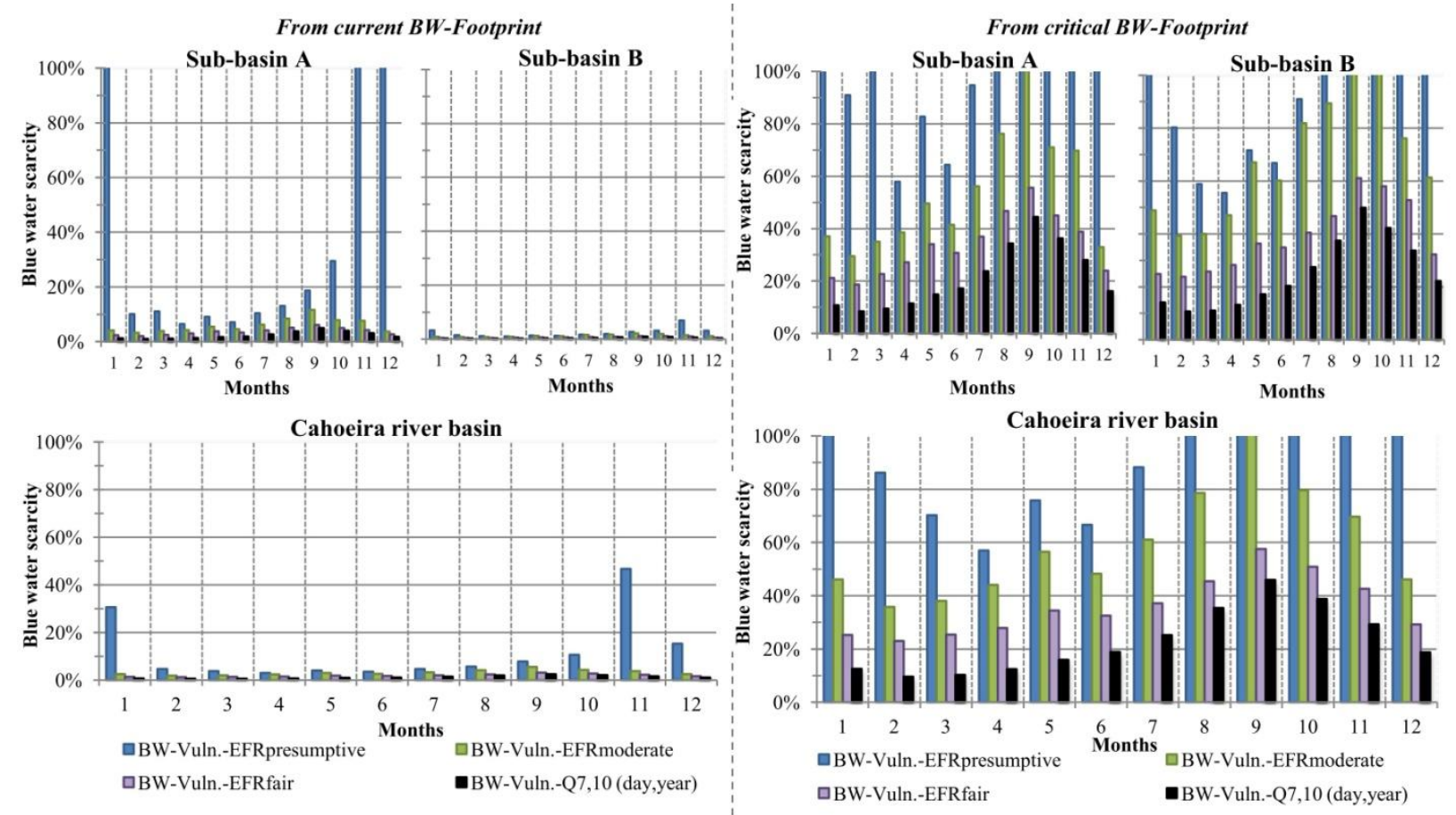

Figure 2.7 - BW-Scarcity due to current and critical consumptive water use (BW-Footprint), considering different EFR methods at the basin and sub-basins studied. . Legend: BW-Scarcity- $\mathrm{Q}_{7,10}$ (from Low Streamflow method); BW-Scarcity-EFR presumptive (from Presumptive Standard method); $\mathrm{BW}-$ Scarcity-EFR moderate, $-\mathrm{EFR}_{\text {fair }}$ (from adapted Smakhtin-metodology for EMCs referring to moderate and fair conservation goals, respectively)

Taking account the critical consumption (defined by a statistical measure, half of $Q_{7,10}$ ), the $B W$-Scarcity estimates indicate different behaviors at the basin and sub-basin scales (Figure 2.7). The sub-basin B resulted in a worse situation than sub-basin A for most of EFR methods. In September, the last month of the drought season (April-September), the BWscarcity based on critical consumption is greater than $40 \%$ for all EFR methods and basin 
scales. At the basin outlet, the indicators values based on $E F R_{\text {presumptive }}$ resulted in $100 \%$ during 6 months (including the dry and rainy periods, August-January), while the $E F R_{\text {moderate }}$, $E F R_{\text {fair }}$, and $Q_{7,10}$ promoted results above $60 \%, 40 \%$, and $30 \%$ from August to November, respectively.

Finally, the restrictive EFR methods (e.g. $E F R_{\text {presumptive }}$ and $E F R_{\text {moderate }}$ ), also significantly affected the $B W$-Vulnerability indicator for several months (Figure 2.8) considering current and critical water abstractions, the later promoted vulnerable conditions in all scales studied during the whole year. In spite of the higher values of scarcity indicator for sub-basin A compared to sub-basin B, the former area seems to have lower vulnerability, due to different patterns of consumptive use and water abstraction and the difference between the statistical measure of water provision for scarcity $\left(50^{\text {th }}\right.$-percentile) and vulnerability (30thpercentile) estimates.
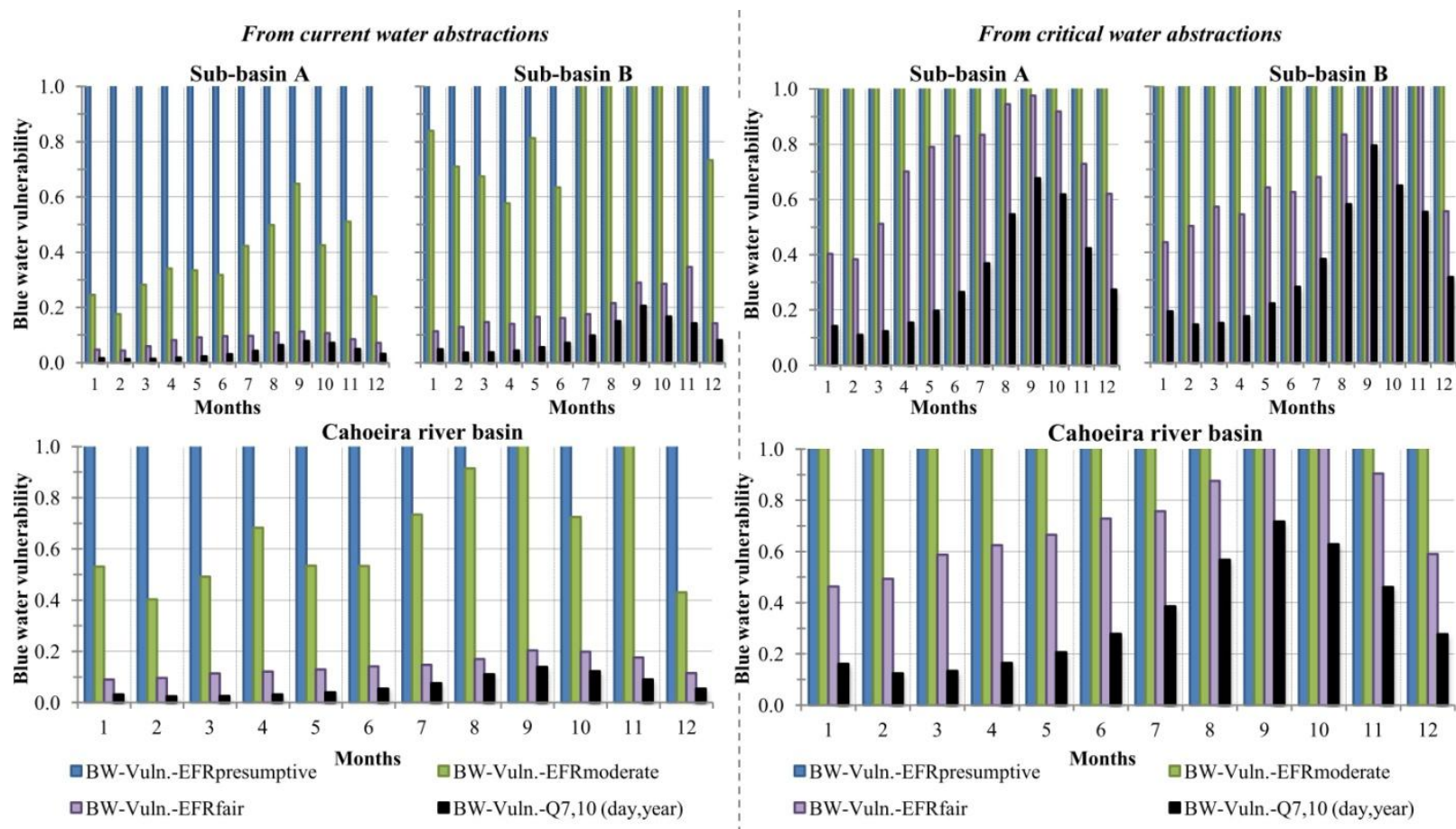

Figure 2.8 - BW-Vulnerability from current and critical water abstractions, considering different EFR methods at the basin and sub-basins studied. Legend: BW-Vuln.- $\mathrm{Q}_{7,10}$ (from Low Streamflow method);

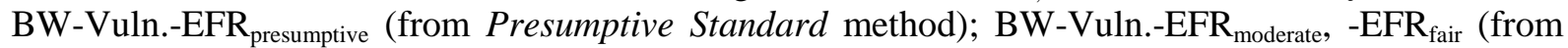
adapted Smakhtin-metodology for EMCs referring to moderate and fair conservation goals, respectively)

\subsection{Potentials and Limitations}

The impact of current and critical/future blue and green water footprint components on median water resources conditions is accounted by the scarcity indicator, while the 
vulnerability indicator considers the probability of low availability of water resources. Consequently, the proposed framework is able to include the effects of changes in amount of water use and availability, and thereby provide insight into damage to economic activities and ecosystem conditions. Further, the use of a monthly analysis helps to reveal temporal patterns in the values of the indicators.

The provision and use of blue/green water resources can be managed individually or jointly while considering irrigated agriculture. Calder (2007) established combinations of blue/green variables for indication of opportunities or limitations for expanding land use areas associated with high crop water requirements. In cases where the green water provision is not sufficient to meet such demand, one must either select rain-fed crops (which can be of relatively low-yield), or complementary irrigation by using blue water. So, a land-use decision is, in that sense, a water decision as well (Falkenmark and Rockström, 2006).

While the blue water demand for human activities can also take into account groundwater rights, essentially in situations containing strongly connected streams, where groundwater consumption can highly influence the availability of surface water, withdrawal rights for groundwater use in our study basin are not significant (only around $0.2 \%$ total volume). We remark, however, that expansion of our framework to consider groundwater resources/demand analysis can be complicated by the fact of boundary differences between hydrogeologic and drainage basins, and other variables should be incorporated to analyze the availability of such resource. Reservoirs also play a very important role as water resources; similarly, they can be incorporated into the framework by taking into account variables related to the operational rules.

Further, while the present assessment of surface BW-footprint has focused on the water rights database, it should be noted that there are additional insignificant water uses that have been recognized by Brazilian water law (n.9433/1997) and the local river basin committee, such as the water supplies accessed by small population clusters scattered throughout the rural areas. Consequently, it will be necessary to develop a detailed study of water abstractions and waste water disposal for those smaller study areas. Such studies must also consider the fact that the water rights must be fully exploited by the users, and that such rights may be partially or entirely suspended if there is inadequate use for three consecutive years (which is intended to discourage speculation by water rights holders, maintain an updated water use database, and manage the water rights for multiple users). Future 
investigation will be necessary to better understand the impacts of uncertainties associated with the permits database and the intra-annual variability of blue water use.

There are, of course, several uncertainties that arise from the use of hydrologicalbased EFR methods that do not incorporate direct measures of aquatic life. So, more complex methods are recommended when a suitable database is available. In our study area, the more restrictive hydrological-based methods are probably more appropriate than the low streamflow $\left(\mathrm{Q}_{7,10}\right)$ method currently employed by Brazilian basin committee, taking into account its conservation targets specified in the basin plan. However, in any given application, several EFR methods should generally be examined to ensure a proper balance between supporting and provisioning ecosystem services, so as to properly consider both the societal needs and the desired conservation status of the river. In addition, by analyzing the hydrological behavior of study basin, other case-by-case adjustments of the framework can be done in regard to the definition of critical probabilistic water provision levels for vulnerability estimation, and severity classification of both scarcity and vulnerability indicators values.

Finally, uncertainties in the scarcity and vulnerability indicators can also arise from residual errors in calibration of the hydrological model. In particular, the BW/GW provision variables, EFR accounting and GW-footprint can be affected by such uncertainties. In ongoing work, a detailed uncertainty analysis of these indicators is being developed to ensure better support for decision making.

\section{Conclusions}

The blue/green water-based accounting framework presented here provides a new arrangement of well-known concepts and methodologies aimed at the assessment of water security at the basin scale and at a monthly analysis. To illustrate the approach, we have evaluated the water security of one of the basins contributing to the Cantareira Water Supply System, which is an important source of water for the city of Sao Paulo. Our findings, demonstrated by the BW-Scarcity indicator level, indicate that the levels of current consumptive water use have a relatively low impact on median water provision, based on an EFR selected for a goal of moderate to high conservation. On the contrary, the critical blue water consumption, defined by the basin authorities, can result in significant impacts especially during dry periods. 
As might be expected, the particular choice of hydrological-based EFR method can have a significant impact on the evaluation. In the case of our study area, taking into account its conservation targets specified in the basin plan, the more restrictive methods are probably more appropriate than the low streamflow $\left(\mathrm{Q}_{7,10}\right)$ method currently employed by Brazilian basin committee. In any given application, several EFR methods should generally be examined to ensure a proper balance between supporting and provisioning ecosystem services, so as to properly consider both the societal needs and the desired conservation status of the river. The natural reasons (drought) for risk of violating EFR levels was evaluated by the freshwater provision indicator that points out the effect of EFR methods in terms of the frequency of monthly mean river discharge being less than EFR.

To look for patterns of scarcity and vulnerability, we have analyzed the blue and green water use against time series and long-term median monthly values of freshwater provision. The vulnerability indicator is associated with low water provision flows ( $30^{\text {th }}$-percentile) and water abstractions, while the scarcity indicator considers the mean water provision flows and water footprint components. In general, the green water scarcity and vulnerability indicators suggest that current conditions in the basin are secure for the development of rain-fed agriculture throughout the year. The analysis of blue and green water reveals a distinct temporal pattern of water scarcity and vulnerability in the study basin. Blue water indicators are highest during the dry (winter) season, while green water indicators are lowest during this period. Further, one of the regions (sub-basin A) is found to have very high levels of both blue and green water scarcity caused by intensive agricultural and current consumptive water use within the sub-basin.

Future investigation will be necessary to better understand a) the uncertainties associated with database and methods using a stochastic approach, b) the effects of climate change projections on blue and green freshwater provision, c) the expansion of the framework involving other sources of water (groundwater and reservoirs), d) specific analysis of critical probabilistic water provision levels for vulnerability estimation and severity classification of both scarcity and vulnerability indicators values., and e) the estimates of non-consumptive water use provided by the Grey Water Footprint component (the water needed for the regulating ecosystem services).

The blue/green water-based accounting framework proposed here provides a comprehensive and relatively simple integration of hydrologic, ecosystem and human needs information on a monthly basis. It can be benchmarked at a range of climate conditions, 
spatial scales, land and water uses, which will be useful to water managers by increasing their understanding of how, where and when, and to what level water-related threats to human and aquatic ecosystem security arise.

\section{Acknowledgements}

The authors are grateful to Danielle A. Bressiani (EESC-USP, Brazil), Dr. Raghavan Srinivasan (Texas A\&M University), Nancy Sammons (ARS-USDA) for advice and help on hydrological modeling with the SWAT model, and to the São Paulo Research Foundation (FAPESP Processes 2011/11653-0, 2012/05515-6, and 2008/58161-1), for supporting the study. The following governmental and non-governmental institutions contributed to the study database: NGOs “Terceira Via”, ISA, PCJ Water Agency; IBGE; Embrapa Soils; INMET; DAEE; SABESP; and ANA. The second author obtained partial support from the EU funded SWAN project (grant 294947) under the EU $7^{\text {th }}$ Framework Programme. We also thank the anonymous reviewers for their very helpful comments and suggestions. The readers can freely access the data from this paper by contacting the first author.

\section{References}

Abbaspour, K. C. (2012). SWAT-CUP 2012: SWAT Calibration and Uncertainty Programs A User Manual. Eawag: Swiss Fed. Inst. of Aquat.Sci. and Technol., Duebendorf, Switzerland, 103 pp. (Available at http://www.neprashtechnology.ca/Downloads.aspx., accessed 23 Nov 2012.)

Abbaspour, K. C., Johnson, C. A., \& Van Genuchten, M. T. (2004). Estimating uncertain flow and transport parameters using a sequential uncertainty fitting procedure. Vadose Zone Journal, 3(4), 1340-1352.

Agencia Nacional de Aguas (2010). Atlas Brasil: Abastecimento Urbano de Agua-Panorama Nacional, vol. 1, Engecorps, Brasilia. (Available at http://atlas.ana.gov.br/Atlas/forms/Home.aspx, accessed 13 May 2013.)

Arnold, J. G., \& Allen, P. M. (1999). Automated Methods for Estimating Baseflow and Ground Water Recharge from Streamflow Records1. Journal of the American Water Resources Association, 35(2), 411-424. doi:10.1111/j.1752-1688.1999.tb03599.x 
Arnold, J. G., Allen, P. M., Muttiah, R., \& Bernhardt, G. (1995). Automated Base Flow Separation and Recession Analysis Techniques. Ground Water, 33(6), 1010-1018. doi:10.1111/j.1745-6584.1995.tb00046.x

Arnold, J. G., Srinivasan, R., Muttiah, R. S., \& Williams, J. R. (1998). Large Area Hydrologic Modeling and Assessment Part I: Model Development1. Journal of the American Water Resources Association, 34(1), 73-89. doi:10.1111/j.1752-1688.1998.tb05961.x

Arnold, J. G., J. R. Kiniry, R. Srinivasan, J. R. Williams, E. B. Haney, and S. L. Neitsch (2011). Soil and Water Assessment Tool input/output file documentation, version 2009, Tech. Rep. 365, Tex. Water Resour. Inst., College Station, Tex.

Association of State Drinking Water Administrators (ASDWA). and National Rural Water Association (NRWA) (2002), Security Vulnerability Self-Assessment Guide for Small Drinking Water Systems, U.S. Environmental Protection Agency (USEPA), Washington, D. C. (Available at http://www.epa.gov/ogwdw/dwa/pdfs/vulnerability.pdf, accessed 23 Jun 2013.)

Bakker, K. (2012). Water Security: Research Challenges and Opportunities. Science, 337(6097), 914-915. doi:10.1126/science.1226337

Barreto, A. C., Freire, M. B. G. dos S., Nacif, P. G. S., Araújo, Q. R., Freire, F. J., \& Inácio, E. dos S. B. (2008). Chemical and physical fractions of soil organic carbon in a forest soil currently under different uses. Revista Brasileira de Ciência do Solo, 32(4), 1471-1478. doi:10.1590/S0100-06832008000400011

Benetti, A. D., Lanna, A. E., \& Cobalchini, M. S. (2004). Current practices for establishing environmental flows in Brazil. River Research and Applications, 20(4), 427-444. doi:10.1002/rra.758

Brasil (2005). Conselho Nacional de Meio Ambiente - CONAMA Resolution n. 357, The Classification of Water Bodies \& Environmental Guidelines for their Framing, as well as Establishing Conditions \& Standards for the Release of Effluents. (Available at http://www.mma.gov.br/port/conama/res/res05/res35705.pdf, accessed 23 May 2013.).

Calder, I. R. (2007). Forests and water-Ensuring forest benefits outweigh water costs. Forest Ecology and Management, 251(1-2), 110-120. doi:10.1016/j.foreco.2007.06.015

Chow, V.T., D.R. Maidment, and L.W. Mays (1988). Applied Hydrology, McGraw-Hill, New York, New York.

DeGasperi, C., \& Burkey, J. (2012), Hydrograph Separation using HYDSEP - Matlab code. (Available at www.mathworks.com/matlabcentral/fileexchange/file_infos/36387hydrograph-separation-using-hydsep, accessed 19 June 2014).

DeLiberty, T. L., \& Legates, D. R. (2003). Interannual and seasonal variability of modelled soil moisture in Oklahoma. International Journal of Climatology, 23(9), 1057-1086. doi:10.1002/joc.904

Douglas-Mankin, K. R., Srinivasan, R., \& Arnold, J. G. (2010). Soil and Water Assessment Tool (SWAT) model: Current developments and applications. Transactions of the ASABE, 53(5), 1423-1431.

EMBRAPA - Brazilian Agricultural Research Corporation (2006). Brazilian Soil Classification System, 2 edition, Embrapa Solos, Rio de Janeiro.

ESRI - Environmental Systems Research Institute (2010). ArcGIS Desktop: Release 10, Redlands, Calif. 
Falkenmark, M., \& Rockström, J. (2006). The new blue and green water paradigm: Breaking new ground for water resources planning and management. Journal of water resources planning and management, 132(3), 129-132.

Falkenmark, M., \& Rockström, J. (2010). Building Water Resilience in the Face of Global Change: From a Blue-Only to a Green-Blue Water Approach to Land-Water Management. Journal of Water Resources Planning and Management, 136(6), 606-610. doi:10.1061/(ASCE)WR.1943-5452.0000118

Food and Agriculture Organization of the United Nations (FAO) (1985). Soil and water, in Irrigation Water Management, Training Manual No. 1, Rome. (Available at http://www.fao.org/docrep/R4082E/r4082e03.htm\#2.4.)

Food and Agriculture Organization of the United Nations (FAO) (2011). The state of the world's land and water resources for food and agriculture (SOLAW)-Managing systems at risk, Food and Agriculture Organization of the United Nations, Rome and Earthscan, London, U. K. (Available at http://www.fao.org/docrep/017/i1688e/i1688e.pdf., accessed 10 Feb 2013.)

Food and Agriculture Organization of the United Nations (FAO) (2012). Coping With Water Scarcity: An Action Framework for Agriculture and Food Security, Rome. (Available at http://www.zaragoza.es/contenidos/medioambiente/onu//newsletter12/880_eng.pdf.)

Food and Agriculture Organization of the United Nations (FAO)/United Nations Educational, Scientific and Cultural Organization (UNESCO) (1974). Soil Map of the World: 1:5.000.000 Legend, vol. 1, Paris.

Gassman, P., Reyes, M., Green, C., \& Arnold, J. (2007). The soil and water assessment tool: historical development, applications, and future research directions. Transactions of the American Society of Agricultural and Biological Engineers, 50(4), 1211-1250.

Glavan, M., Pintar, M., \& Volk, M. (2013). Land use change in a 200-year period and its effect on blue and green water flow in two Slovenian Mediterranean catchments-lessons for the future. Hydrological Processes, 27(26), 3964-3980. doi:10.1002/hyp.9540

Grey, D., \& Sadoff, C. W. (2007). Sink or Swim? Water security for growth and development. Water Policy, 9(6), 545. doi:10.2166/wp.2007.021

Gupta, H. V., Sorooshian, S., \& Yapo, P. O. (1999). Status of Automatic Calibration for Hydrologic Models: Comparison with Multilevel Expert Calibration. Journal of Hydrologic Engineering, 4(2), 135-143. doi:10.1061/(ASCE)1084-0699(1999)4:2(135)

Gupta, H. V., Kling, H., Yilmaz, K. K., \& Martinez, G. F. (2009). Decomposition of the mean squared error and NSE performance criteria: Implications for improving hydrological modelling. Journal of Hydrology, 377(1-2), 80-91. doi:10.1016/j.jhydrol.2009.08.003

Hickmann, C., Costa, L. M. da, Schaefer, C. E. G. R., Fernandes, R. B. A., \& Andrade, C. de L. T. (2011). Atributos físico-hidricos e carbono orgânico de um argissolo após 23 anos de diferentes manejos. Revista Caatinga, 25(1), 128-136.

Hoekstra, A. Y., \& Hung, P. Q. (2002), Virtual water trade: a quantification of virtualwater flows between nations in relation to international crop trade, Value of Water Research Report Series, n.11, UNESCO-IHE, Delft.

Hoekstra, A. Y., Chapagain, A. K. Aldaya, M. M., \& Mekonnen, M. M. (2011). The water footprint assessment manual: Setting the global standard, Earthscan, London. 
Hoekstra, A. Y., Mekonnen, M. M., Chapagain, A. K., Mathews, R. E., \& Richter, B. D. (2012). Global Monthly Water Scarcity: Blue Water Footprints versus Blue Water Availability. PLoS ONE, 7(2), e32688. doi:10.1371/journal.pone.0032688

Honrado, J. P., Vieira, C., Soares, C., Monteiro, M. B., Marcos, B., Pereira, H. M., \& Partidário, M. R. (2013). Can we infer about ecosystem services from EIA and SEA practice? A framework for analysis and examples from Portugal. Environmental Impact Assessment Review, 40, 14-24. doi:10.1016/j.eiar.2012.12.002

Hughes, D. A., \& Hannart, P. (2003). A desktop model used to provide an initial estimate of the ecological instream flow requirements of rivers in South Africa. Journal of Hydrology, 270(3), 167-181.

Jha, M. K. (2011). Evaluating Hydrologic Response of an Agricultural Watershed for Watershed Analysis. Water, 3(4), 604-617. doi:10.3390/w3020604

Krause, P., Boyle, D. P., \& Bäse, F. (2005). Comparison of different efficiency criteria for hydrological model assessment. Adv. Geosci., 5, 89-97. doi:10.5194/adgeo-5-89-2005

Legates, D. R., \& McCabe, G. J. (1999). Evaluating the use of "goodness-of-fit" Measures in hydrologic and hydroclimatic model validation. Water Resources Research, 35(1), 233241. doi:10.1029/1998WR900018

Lima, A. M. N., Silva, I. R. da, Stape, J. L., Mendonça, E. S., Novais, R. F., Barros, N. F. de, ... Soares, E. M. B. (2011). Modeling changes in organic carbon stocks for distinct soils in southeastern brazil after four eucalyptus rotations using the century model. Revista Brasileira de Ciência do Solo, 35(3), 833-847. doi:10.1590/S0100-06832011000300018

Logsdon, R. A., \& Chaubey, I. (2013). A quantitative approach to evaluating ecosystem services. Ecological Modelling, 257, 57-65. doi:10.1016/j.ecolmodel.2013.02.009

Montanari, A., Young, G., Savenije, H. H. G., Hughes, D., Wagener, T., Ren, L. L., ... Belyaev, V. (2013). "Panta Rhei-Everything Flows": Change in hydrology and societyThe IAHS Scientific Decade 2013-2022. Hydrological Sciences Journal, 58(6), 12561275. doi:10.1080/02626667.2013.809088

Monteith, J.L. (1965), Evaporation and environment. Symp. Sot. Exp. Biol., 19: 205-234.

Moriasi, D., Arnold, J., Van Liew, M., Bingner, R., Harmel, R., \& Veith, T. (2007). Model Evaluation Guidelines for Systematic Quantification of Accuracy in Watershed Simulations. Transactions of the ASABE, 50(3), 885-900.

Nash, J. E., \& Sutcliffe, J. V. (1970). River flow forecasting through conceptual models part I - A discussion of principles. Journal of Hydrology, 10(3), 282-290. doi:10.1016/00221694(70)90255-6

Neitsch, S. L., J. G. Arnold, J. R. Kiniry, and J. R. Williams (2011), SWAT theoretical documentation version 2009, Soil and Water research laboratory. Grassland.

O'Keeffe, J. (2009). Sustaining river ecosystems: balancing use and protection. Progress in Physical Geography, 33(3), 339-357. doi:10.1177/0309133309342645

Oki, T., \& Kanae, S. (2006). Global hydrological cycles and world water resources. science, 313(5790), 1068-1072. doi:10.1126/science.1128845

Padowski, J. C., \& Jawitz, J. W. (2012). Water availability and vulnerability of 225 large cities in the United States. Water Resources Research, 48(12), W12529. doi:10.1029/2012WR012335 
Peel, M. C., Finlayson, B. L., \& McMahon, T. A. (2007). Updated world map of the KöppenGeiger climate classification. Hydrology and Earth System Sciences Discussions, 4(2), 439-473. doi:10.5194/hessd-4-439-2007

Piracicaba, Capivari e Jundiaí rivers basin committee (PCJ) (2011), Plano das bacias hidrográficas dos rios Piracicaba, Capivari e Jundiaí 2010-2020: relatório síntese, Cobrape, São Paulo. (Available at http://www.comitepcj.sp.gov.br/download/PB/PCJ_PB2010-2020_Sintese.pdf, accessed 10 Jan. 2013.).

Porto, M. (1998). The Brazilian Water Law: A New Level of Participation and Decision Making. International Journal of Water Resources Development, 14(2), 175-182. doi:10.1080/07900629849385

Porto, R. L. L., \& Porto, M. F. A. (2002). Planning as a Tool to Deal with Extreme Events. Water International, 27(1), 14-19. doi:10.1080/02508060208686973

Reilly, C. F., \& Kroll, C. N. (2003). Estimation of 7-day, 10-year low-streamflow statistics using baseflow correlation. Water Resources Research, 39(9), n/a-n/a. doi:10.1029/2002WR001740

Richter, B. D., Davis, M. M., Apse, C., \& Konrad, C. (2012). A Presumptive Standard for Environmental Flow Protection. River Research and Applications, 28(8), 1312-1321. doi:10.1002/rra.1511

Rockström, J., Falkenmark, M., Karlberg, L., Hoff, H., Rost, S., \& Gerten, D. (2009). Future water availability for global food production: the potential of green water for increasing resilience to global change. Water Resources Research, 45(7), W00A12.

Sao Paulo State (1994). Law n. 9034. Water Resources State Plan. (Available at http://www.jusbrasil.com.br/legislacao/174303, accessed 01 May 2012)

Sartori, A., Neto, F. L., \& Genovez, A. M. (2005). Classificação Hidrológica de Solos Brasileiros para a Estimativa da Chuva Excedente com o Método do Serviço de Conservação do Solo dos Estados Unidos Parte 1 : Classificação, 10, 5-18.

Saxton, K., \& Willey, P. (2005). The SPAW Model for Agricultural Field and Pond Hydrologic Simulation. In Watershed Models (Vols. 1-0, p. 400-435). CRC Press. doi:10.1201/9781420037432.ch17

Saxton, K. E., \& Rawls, W. J. (2006). Soil Water Characteristic Estimates by Texture and Organic Matter for Hydrologic Solutions. Soil Science Society of America Journal, 70(5), 1569. doi:10.2136/sssaj2005.0117

Schuol, J., Abbaspour, K. C., Srinivasan, R., \& Yang, H. (2008). Estimation of freshwater availability in the West African sub-continent using the SWAT hydrologic model. Journal of Hydrology, 352(1-2), 30-49. doi:10.1016/j.jhydrol.2007.12.025

Scott, C. A., Meza, F. J., Varady, R. G., Tiessen, H., McEvoy, J., Garfin, G. M., Wilder, M. Farfán, L. M. Pablos, N. P., Montaña, E. (2013). Water Security and Adaptive Management in the Arid Americas. Annals of the Association of American Geographers, 103(2), 280-289. doi:10.1080/00045608.2013.754660

Seibert, J. (1999). Regionalisation of parameters for a conceptual rainfall-runoff model. Agricultural and Forest Meteorology, 98-99, 279-293. doi:10.1016/S01681923(99)00105-7 
Sharpley, A. N. and J. R. Williams (1990), EPIC-Erosion/Productivity Impact Calculator: 1Model Documentation, Technical Bulletin 1768, U.S. Department of Agriculture/Agricultural Research Service, Washington, D. C.

Sloto, R. A., and M. Y. Crouse (1996), HYSEP, a computer program for streamflow hydrograph separation and analysis, Water-resources investigations report; 96-4040, U.S. Dept. of the Interior, U.S. Geological Survey; Branch of Information Services, Lemoyne, Pennsylvania. (Available at https://water.usgs.gov/software/HYSEP/code/doc/hysep.pdf, accessed 19 June 2014)

Smakhtin, V., Revenga, C., \& Döll, P. (2004). A pilot global assessment of environmental water requirements and scarcity. Water International, 29(3), 307-317.

Smakhtin, V. U., \& Eriyagama, N. (2008). Developing a software package for global desktop assessment of environmental flows. Environmental Modelling \& Software, 23(12), 13961406. doi:10.1016/j.envsoft.2008.04.002

Sullivan, C. A. (2011). Quantifying water vulnerability: a multi-dimensional approach. Stochastic Environmental Research and Risk Assessment, 25(4), 627-640. doi:10.1007/s00477-010-0426-8

Tharme, R. E. (2003). A global perspective on environmental flow assessment: emerging trends in the development and application of environmental flow methodologies for rivers. River Research and Applications, 19(5-6), 397-441. doi:10.1002/rra.736

The Guardian. (2014). São Paulo faces a critical water shortage as the World Cup prepares to kick off, May 21th 2014. (Available at http://www.theguardian.com/sustainablebusiness/sao-paulo-water-shortage-world-cup, accessed May 21, 2014).

United States Department of Agriculture (USDA) (1975). Soil Taxonomy: A Basic System of Soil Classification for Making and Interpreting Soil Surveys, Agric. Handbook Ser. No. 436, Washington, D. C.

United States Department of Agriculture (USDA) (1986). Urban hydrology for small watersheds, Tech. Release 55, Soil Conserv. Serv., Washington, D. C.

United States Environmental Protection Agency (USEPA) (1995). Cleaner water through conservation, Rep. EPA-841/B-95-002, Off. of Wetlands, Oceans and Watersheds, Washington, D. C. (Available at http://nepis.epa.gov/Exe/ZyPURL.cgi?Dockey520004MQA.txt., accessed 23 Jul 2013.)

Van Griensven, A., Ndomba, P., Yalew, S., \& Kilonzo, F. (2012). Critical review of the application of SWAT in the upper Nile Basin countries. Hydrol. Earth Syst. Sci. Discuss., 9(3), 3761-3788. doi:10.5194/hessd-9-3761-2012

Van Loon, A. F., \& Van Lanen, H. a. J. (2013). Making the distinction between water scarcity and drought using an observation-modeling framework. Water Resources Research, 49(3), 1483-1502. doi:10.1002/wrcr.20147

Vörösmarty, C. J., McIntyre, P. B., Gessner, M. O., Dudgeon, D., Prusevich, A., Green, P., et al. (2010). Global threats to human water security and river biodiversity. Nature, 467(7315), 555-561. doi:10.1038/nature09440

Whately, M., and P. Cunha (2007). Cantareira 2006: um olhar sobre o maior manancial de água da Região Metropolitana de São Paulo, Inst.Socioambiental, São Paulo, Brazil. (Available at http://www.socioambiental.org/banco_imagens/pdfs/10289.pdf., accessed 23 May 2012.) 
White, K. L., \& Chaubey, I. (2005). Sensitivity Analysis, Calibration, and Validations for a Multisite and Multivariable Swat Model1. Journal of the American Water Resources Association, 41(5), 1077-1089. doi:10.1111/j.1752-1688.2005.tb03786.x

Wilby, R. L., Fenn, C. R., Wood, P. J., Timlett, R., \& LeQuesne, T. (2011). Smart licensing and environmental flows: Modeling framework and sensitivity testing. Water Resources Research, 47(12), W12524. doi:10.1029/2011WR011194

Williams, J. R. (1995). The EPIC Model, in Computer Models of Watershed, edited by V.P. Singh, pp. 909-1000. Water Resources Publications, Highlands Ranch, Colorado.

Winchell, M., Srinivasan, R., Di Luzio, M., and Arnold, J. G. (2007), ArcSWAT Interface for SWAT2005-User's Guide, Blackland Res. Cent., Tex. Agric. Exp. Stn. and Grassland, Soil and Water Res. Lab., USDA Agric. Res. Serv., Temple, Tex.

Zeitoun, M. (2011). The Global Web of National Water Security. Global Policy, 2(3), 286296. doi:10.1111/j.1758-5899.2011.00097.x

Zeng, Z., Liu, J., Koeneman, P. H., Zarate, E., \& Hoekstra, A. Y. (2012). Assessing water footprint at river basin level: a case study for the Heihe River Basin in northwest China. Hydrology and Earth System Sciences Discussions, 9(5), 5779-5808. doi:10.5194/hessd9-5779-2012

Zhang, X., Srinivasan, R., Zhao, K., \& Liew, M. V. (2009). Evaluation of global optimization algorithms for parameter calibration of a computationally intensive hydrologic model. Hydrological Processes, 23(3), 430-441. doi:10.1002/hyp.7152. 


\title{
CHAPTER 3 \\ ASSESSING UNCERTAINTIES IN SURFACE WATER SECURITY: A \\ PROBABILISTIC MULTI-MODEL RESAMPLING APPROACH*
}

*A modified version of this chapter has been submitted as: Rodrigues, D. B. B., Gupta, H. V., \& Mendiondo, E. M. Assessing uncertainties in surface water security: a probabilistic multimodel resampling approach, Water Resources Research. (Journal impact factor: 3.709; Qualis CAPES: A1)

\begin{abstract}
Various uncertainties are involved in the representation of processes that characterize interactions between societal needs, ecosystem functioning, and hydrological conditions. Here, we develop an uncertainty assessment of water security indicators that characterize scarcity and vulnerability, based on a multi-model and resampling framework. We consider several uncertainty sources including those related to: i) observed streamflow data; ii) hydrological model structure; iii) residual analysis; iv) the Environmental Flow Requirement; v) the definition of critical conditions for water provision; and vi) the critical demand imposed by human activities. We estimate the overall uncertainty coming from the hydrological model by means of a residual bootstrap resampling approach, and by uncertainty propagation through different methodological arrangements applied to a $291 \mathrm{~km}^{2}$ agricultural basin within the Cantareira water supply system in Brazil. Together, the two-component hydrograph residual analysis and the block bootstrap resampling approach result in a more accurate and precise estimate of the uncertainty ( $95 \%$ confidence intervals) in the simulated time series. We then compare the uncertainty estimates associated with water security indicators developed using a multi-model framework and provided by each model uncertainty estimation approach. The method is general, and can form the basis for meaningful support to end-users facing water resource challenges by enabling them to incorporate a viable uncertainty analysis into a robust decision making process.
\end{abstract}

Key-words: HYMOD model; SWAT model; Environmental Flow Requirement; Bootstrap; Water Scarcity; Water Vulnerability 


\section{Introduction}

Opposing trends in water use and water availability lead to concerns about water security risks, however such evaluation is complicated by a variety of sources of uncertainty in the representations of hydrological processes, and of human and environmental water demands. Uncertainty can also arise from expert judgments about the selection of appropriate data or analysis methods, and about how to interpret the data and modeling results (Gregory et al., 2012). A major challenge faced by water managers arises from the many possible combinations and implementation schedules of infrastructure development, supply vs. demand management, institutions and policies etc. (Matrosov et al., 2013). Robust strategies are necessary for decisions taken under uncertainty, so that they perform well (though not necessarily optimally) over a wide range of current and potential future conditions (Lempert et al., 2006; Wilby and Dessai, 2010).

At least four important sources of uncertainty arise when generating streamflow simulations using deterministic hydrological models, these being uncertainties due to a) errors in the data used to calibrate the model, b) bias and/or imprecision in the parameter estimates, c) incomplete or biased model structure, and d) errors in the input data used to drive the model (Butts et al., 2004). While a classical approach to quantifying uncertainty is to develop predictions in the form of probability distributions, the high degree of nonlinearity and complex interactions within a hydrologic system make it difficult to accurately represent the joint probability distributions of the uncertainties involved (Liu and Gupta, 2007). Further, the challenge of understanding complex systems often gives rise to a multiplicity of alternative model structural hypotheses (Clark et al., 2011; Rougier et al., 2013). As a complement to the exploration of single-model uncertainties through parameter perturbation experiments, a number of papers now explore the assessment of model structural uncertainty by running multi-model ensembles that provide sets of model simulations from structurally different models and a variety of initial conditions (Tebaldi and Knutti, 2007).

It has been reported that combining ensemble models outputs can provide more robust and informative predictions of system response than are achieved by examining the outputs of each model individually (Rougier et al., 2013). For example, multi-model projections are now routinely used in long-term climate change studies, and recent reports by the Intergovernmental Panel on Climate Change present multi-model results as best guess projections (Tebaldi and Knutti, 2007). Because statistical frameworks are essential to 
quantify the uncertainties associated with an estimate of mean climate change response, the "one model, one vote" approach serves as a general way to develop a weighted climate projection (Sansom et al., 2013). These projections can then be used to assess uncertainties in climate change impacts; for example Wilby and Harris (2006) did so using two hydrological model structures weighted by their performance in reproducing annual low-flow series.

Because the sources of uncertainty are many, a pragmatic approach to operational water resources assessment is to employ an empirical evaluation of model output uncertainties, thereby considering all relevant sources of uncertainty without the need to separate out each error source (Malone et al., 2011). Monte-Carlo sampling methods are now widely used, that sample the uncertainty space and run the hydrologic model(s) forward to provide an empirical quantification of the uncertainty in the model outputs (Liu and Gupta 2007).

Further, empirical construction of a population probability distribution can be performed via the Bootstrap technique (Efron, 1979), which employs a method of random resampling with replacement (Tasker, 1987), and needs little or no prior assumptions regarding the underlying mathematical form of the distribution (Ebtehaj et al., 2010). The bootstrap method has been used in a number of hydrological studies including: a comparison between low flow methods (Tasker, 1987), evaluation of uncertainties in frequency analysis of rainfall and flood extremes (Zucchini and Adamson, 1989; Hu et al., 2013); evaluation of uncertainties in streamflow time series (Lall and Sharma, 1996; Vogel and Shallcross, 1996; Srinivas and Srinivasan, 2005), developing a sample distribution of optimal parameters during calibration (Ebtehaj et al., 2010); evaluation of uncertainties in flow series based on the rating curve (Shao et al., 2014); evaluation of uncertainties in rainfall estimates derived from gauge observations (Shao et al., 2012); and evaluation of uncertainties in model parameters via bootstrapping of model residuals (e.g., Selle and Hannah, 2010; Li et al., 2010; Zhang et al., 2014).

In particular, Li et al. (2010) suggest that block bootstrapping of model residuals could be helpful in understanding how all of the error sources contribute to the total simulation uncertainty. To preserve the stationarity characteristics of the original data, the Block Bootstrap method resamples on blocks of consecutive observations, with the optimal block size estimated based on an analysis of autocorrelation structure (Hall et al., 1995; Vogel and Shallcross, 1996; Politis and White, 2004; Patton et al., 2009), or using probabilistic common sense (Lall and Sharma, 1996; Srinivas and Srinivasan, 2005). 
In this paper, we conduct an uncertainty assessment of scarcity and vulnerability indicators that characterize water security conditions (Rodrigues et al., 2014), based on a combined multi-model and resampling framework that includes two hydrological models, four EFR methods, two methods of model residual analysis (using one- and two-component hydrographs), and two methods of model residual bootstrapping (Block and Model-based) to assess overall model uncertainty. In addition we account for errors in observed data and uncertainties in the definitions of critical levels of water provision and use for human activities. The multi-model results were aggregated by weighting them according to their individual levels of performance. The approach is demonstrated for a study basin in the Southeast of Brazil, close to the Metropolitan Region of Sao Paulo.

\section{Material and Methods}

To illustrate our approach for uncertainty assessment of water security indicators (Figure 3.1), we investigate an agricultural basin $\left(291 \mathrm{~km}^{2}\right)$, located upstream of the Cachoeira reservoir $\left(46^{\circ} 16^{\prime} 18^{\prime \prime} \mathrm{W} 23^{\circ} 1^{\prime} 25^{\prime \prime S}\right.$ to $46^{\circ} 6^{\prime} 21^{\prime \prime} \mathrm{W} 22^{\circ} 50^{\prime} 56^{\prime \prime S}$, Figure 3.2), within the Cantareira water supply system and the Piracicaba river basin in Brazil.

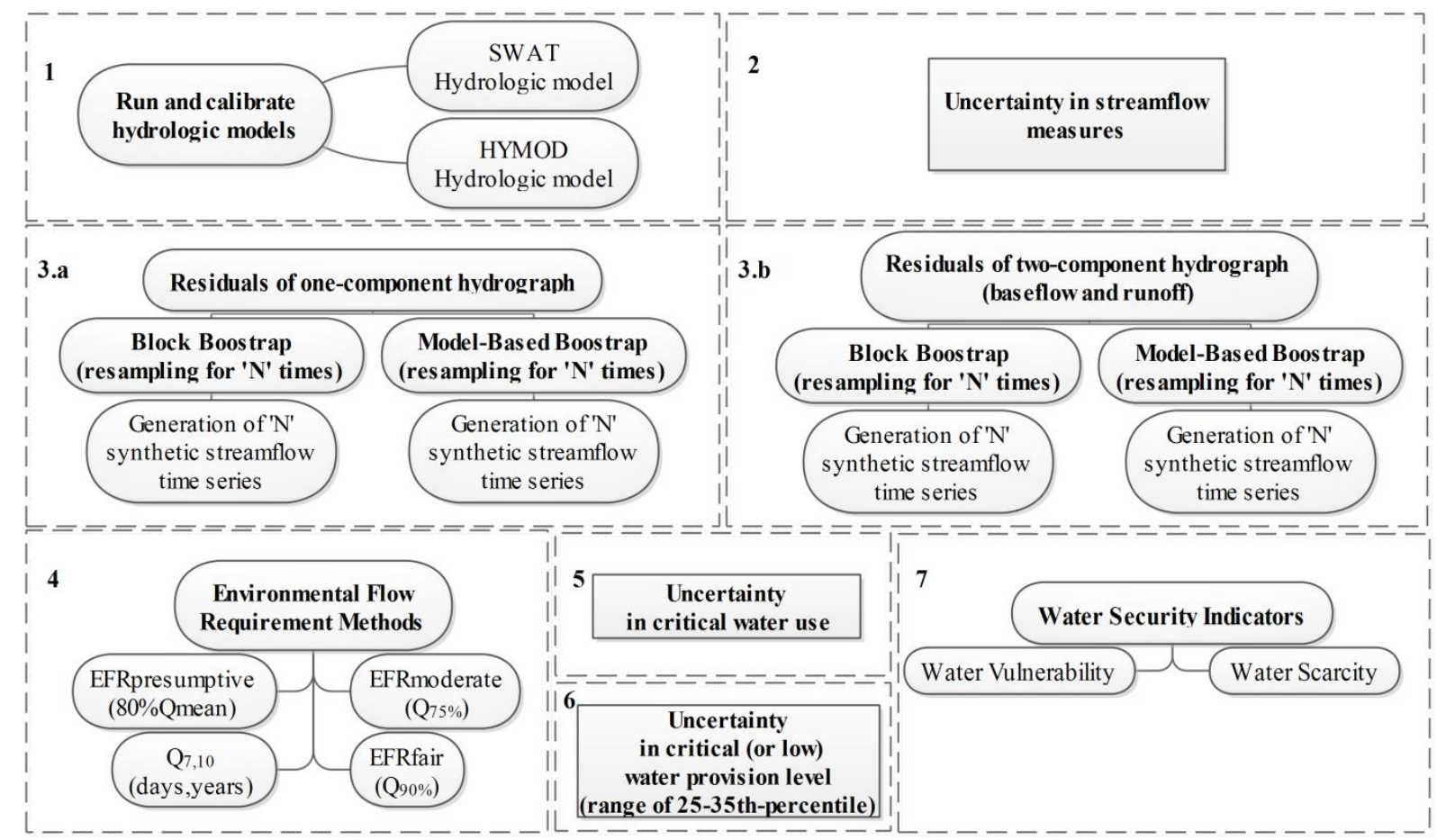

Figure 3.1 - Methodological scheme of the probabilistic multi-model and resampling approach 
This study basin has significant social relevance for water security studies, because the Cachoeira reservoir contributes about $15 \%$ of the total water supplied by the Cantareira system to about 9 million people in the Metropolitan Region of Sao Paulo (Southwestern Brazil) (Whately and Cunha, 2007). In addition, the river basin plan that covers this basin is called the Piracicaba-Capivari-Jundiai River Basin Plan, and considers the region as requiring "Protection and Control" (PCJ, 2011).

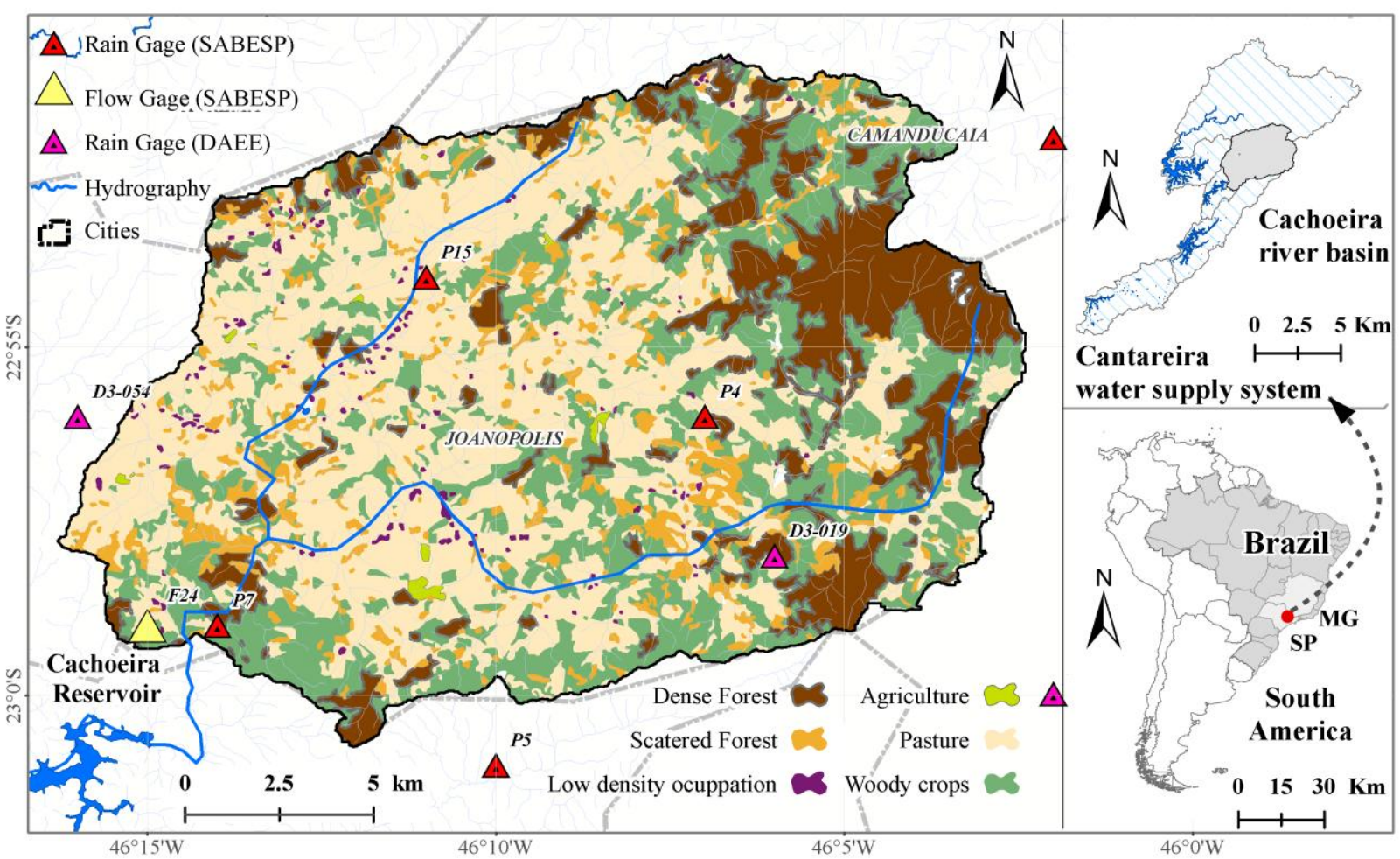

Figure 3.2 - Study area represented by Cachoeira river basin $\left(291 \mathrm{~km}^{2}\right)$, which is covered by land use map correspondent to reference year 2010. The locations of hydrological gages are shown

\subsection{Water Security assessment}

Standardized assessments of scarcity and vulnerability can provide a useful basis by which societies can increase their water security and better prepare for future conditions (Padowski and Jawitz, 2012; Sullivan, 2011). Here, we employ part of the methodology proposed by Rodrigues et al. (2014), to demonstrate how a quantitative analysis of the probability of surface water ("Blue water") provision and use (abstraction and consumption) can be conducted, thereby assessing uncertainty in estimates of water scarcity and vulnerability for the aforementioned Brazilian basin. 
The scarcity indicator evaluates the impacts of water use on median water provision conditions, whereas the vulnerability indicator considers the probability of low availability of water provision (Rodrigues et al., 2014). Estimates of "blue" water provision for human activities take into account the availability of water (in the rivers) for consumptive water use (Hoekstra et al., 2011), while satisfying monthly Environmental Flow Requirements (EFR) (Eqs. 1 to 3).

Water Provision $_{(i, x, t)}=Q_{(x, t)}-E F R_{(i, x, t)}$

Water Scarcity $_{(i, x, t)}=$ Water Consumption $_{(x, t)} /$ Median Water Provision $_{(i, x, t)}$

Water Vulnerability $_{(i, x, t)}={\text { Water } \text { Abstraction }_{(x, t)}}_{\text {Low Water Provision }}^{(i, x, t)}$

where the Water Provision(x,t) is computed for a specific location $(\mathrm{x})$ and time of the year $(\mathrm{t})$ $\left(\mathrm{L}^{3} \mathrm{~T}-1\right), \mathrm{Q}(\mathrm{x}, \mathrm{t})$ is the corresponding daily streamflow in the river $\left(\mathrm{L}^{3} \mathrm{~T}-1\right)$, and $\mathrm{EFR}(\mathrm{i}, \mathrm{x}, \mathrm{t})$ is the corresponding fraction of river discharge maintained to meet Environment Flow Requirements for a specific month of the year and hydrological-based method (indexed by i) (L $\left.{ }^{3} \mathrm{~T}-1\right)$. Similarly, Water consumption(x,t) represents the consumptive water use for human activities at a specific location (sub-basin) and time (month) of the year, and Median Water Provision $(\mathrm{x}, \mathrm{t})$ takes into account the 50th percentile of Water Provision $(\mathrm{x}, \mathrm{t})$ for each EFR method (indexed by i) ( $\left.\mathrm{L}^{3} \mathrm{~T}-1\right)$. Finally, Water Abstraction( $\left.\mathrm{x}, \mathrm{t}\right)$ is the corresponding sum of water permits for abstraction within the basin $\left(\mathrm{L}^{3} \mathrm{~T}-1\right)$, and Low Water Provision $(\mathrm{i}, \mathrm{x}, \mathrm{t})$ is the low-flow volume of Water Provision at $\mathrm{x}$ and $\mathrm{t}$ for each EFR method (indexed by i), represented by a specific value of percentile of the records $\left(\mathrm{L}^{3} \mathrm{~T}-1\right)$.

In this paper, we assess the uncertainty of estimates of these water security indicators via a methodological scheme (Figure 3.1) that considers the uncertainties in simulated streamflow time series (steps 1 to 3 ) and other sources (steps 4 to 6), including EFR methods, and definition of critical levels of water use (consumptive and abstraction) and low level of water provision.

Note that the EFR quantifies the amounts of water that must be kept flowing down a river to maintain quality, quantity and temporality required to achieve environmental goals. In any given application, several EFR methods should generally be examined to ensure a proper 
balance between supporting and provisioning ecosystem services, so as to properly consider both the societal needs and the desired conservation status of the river (Rodrigues et al., 2014). These values are estimated here by four hydrological-based methods (probability of exceedance, fraction of long-term mean, or 7-day 10-year low flow) (Table 3.1).

Table 3.1 - Methods for Evaluating Environmental Flow Requirements

\begin{tabular}{ll}
\hline EFR method & Description \\
\hline i) EFRpresumptive & 80\% of long-term mean (Richer et al. 2012) \\
\hline ii) EFRmoderate & Probability of exceedance in according to conservation goals: Q75\% for \\
iii) EFRfair & moderate conservation (EFRmoderate, slightly or moderately modified basin, \\
& with minor water supply schemes or irrigation development); and Q90\% for \\
& fair conservation (EFRfair, considerably modified basin, with multiple \\
& disturbances associated with socio-economic development) (Smakhtin et al., \\
& 2004; Smakhtin and Eriyama, 2008) \\
\hline $\begin{array}{l}\text { iv) 7-day 10-year low flow } \\
\text { (Q7,10 })\end{array}$ & $\begin{array}{l}\text { Annual average 7-day minimum flow that is expected to be exceeded on } \\
\text { average in 9 out of every 10 years (Reily and Kroll, 2003). }\end{array}$ \\
\hline
\end{tabular}

Water vulnerability and scarcity indicators take into account critical water use values (consumptive and abstraction), defined by the Water Resources State Plan reported in the Law 9034/1994 (Sao Paulo State, 1994) and computed as 50\% (fifty per cent) of the current reference streamflow (i.e. Q7,10, 7-day, 10-year low flow). Thus, the uncertainties in critical water consumption and abstraction are associated with statistical estimates of low streamflow $(Q 7,10)$. In turn, the uncertainties in definition of critical conditions for estimation of water vulnerability indicator are established within the range of 25th to 35th-percentile of water provision, which value is randomly sampled.

\subsection{Hydrological Modeling}

To achieve a practical demonstration of the structural uncertainties associated with selection of a hydrological model, we employ two quite different models: the physicallybased semi-distributed Soil and Water Assessment Tool (SWAT) (Arnold et al., 1998) and the lumped conceptual model HYMOD (Wagener et al., 2001). While a larger number of models could be used, the choice of these two rather different modeling approaches serves to illustrate the main aspects of a multi-model assessment.

\subsubsection{Soil and Water Assessment Tool (SWAT) model}

The Soil and Water Assessment Tool (SWAT) model was created in the early 1990s, and has been continually improved and widely used for hydrological and non-point source 
pollution assessment (Gassman et al., 2007). The minimum data required to use this model includes a digital elevation model (DEM) to characterize topography, soil properties (in different layers), vegetation cover, meteorological (solar radiation, wind speed, maximum and minimum air temperature, and relative air humidity) and hydrological (precipitation) time series. Various other data can be incorporated for replacing default values with location specific ones, and to improve the model accuracy at a specific location.

The SWAT model uses a basin discretization that partitions the study area into a number of subbasins and Hydrologic Response Units (HRUs) that comprise land areas within the subbasin having unique land use, soil and slope classes (Neitsch et al., 2011). A simulation of hydrological processes is conducted for each HRU, and the output water fluxes are routed to the watershed outlet to obtain total streamflow values. Accordingly, the hydrological processes are separated into two major divisions, the land phase of hydrologic cycle that determines the amount of water delivered to the main channel in each subbasin, and the routing of flow through the channel network to the basin outlet (Neitsch et al., 2011). In each HRU, the water moves through a sequence of six linear reservoirs that represent vegetation cover, snow accumulation and melt, surface storage, soil profile storage, shallow aquifer storage, and streamflow, to generate the components of the water balance according to:

$S W t=S W o+P-Q s u r f-E v t-W s e e p-Q g w$

where SWt is the final soil water content, SWo is the initial soil water content, $\mathrm{P}$ is the amount of precipitation, $\mathrm{Ea}$ is the amount of evapotranspiration, Wseep is the amount of seepage water (from the soil profile to vadose zone), Qgw is the amount of groundwater contribution to streamflow (return flow).

Of the many SWAT model parameters, we followed standard practice and selected 13 of them to calibrate or alter away from their default values (Table 3.2); details regarding the calibration process appear in Rodrigues et al. (2014), which also specifies the data sources used for inputs to the SWAT model. 
Table 3.2 - Streamflow-related SWAT parameter values that were calibrated or changed from their default values

\begin{tabular}{lll}
\hline Main parameters function & SWAT parameter & \\
\hline Surface water response & Soil evaporation compensation factor & ESCO ${ }^{1}$ \\
& SCS runoff Curve Number (average soil moisture condition) & CN2 \\
& Maximum canopy index (mm) & CANMX \\
& Manning's value for overland flow & OV_N \\
& Available soil water capacity $\left(\mathrm{mm} \mathrm{mm}^{-1}\right)$ & SOL_AWC \\
\hline Basin response & Surface runoff lag coefficient $($ days) & SURLAG \\
& Manning coeficient for channel & CH_N2 \\
\hline Groundwater response & Soil hydraulic conductivity $\left(\mathrm{mm} \mathrm{h}^{-1}\right)$ & SOL_K \\
& Delay time for aquifer recharge (days) & GW_DELAY \\
& Groundwater revap coefficient & GW_REVAP \\
& Baseflow recession constant (days) & ALPHA_BF \\
& Fraction of water percolation to deep aquifer (fraction) & RCHRG_DP \\
& Threshold water level in shallow aquifer for base flow (mm) & GWQMN \\
\hline
\end{tabular}

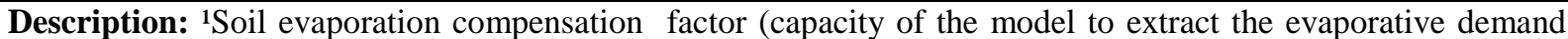
from soil layers, by inverse relationship); ${ }^{2}$ Maximum canopy index: maximum amount of water that can be trapped in the vegetation canopy $(\mathrm{mm}) ;{ }^{3}$ factor to lag a portion of the surface runoff release to the main channel (days); ${ }^{4}$ time lag between the time that water exits the soil profile and enters the shallow aquifer (days); ${ }^{5}$ regulates the movement of water from the shallow aquifer to the root zone in response to moisture deficit; ${ }^{6}$ response index of groundwater flow (into the main channel) to changes in shallow aquifer recharge (days);

\subsubsection{HYMOD model}

The HYMOD model (Boyle, 2000; Wagener, 2001) is a relatively simple spatially lumped "rainfall excess" type model, that has been shown to provide reasonable simulation results while being computationally very fast, having a minimal requirement for input flux data (precipitation and potential evapotranspiration time-series), and requiring calibration of only five parameters (Table 3.3). The model has been widely used in studies related to climate change impacts, assessment of methods for model calibration, uncertainty analysis, data assimilation, and many others (e.g., Vrugt et al., 2005, Moradkhani et al., 2005, Bastola and Misra, 2013; Gong et al., 2013; Chen et al, 2013). In brief, the model uses a nonlinear tank (soil moisture component) to generate rainfall excess, connected with two parallel series of linear tanks (for quick and slow responses) to rout the flow to the basin outlet (Bastola and Misra, 2013). The streamflow output is the sum of slow and fast components, while actual evapotranspiration is crudely simulated as the minimum of potential evapotranspiration and soil moisture. The data sources for HYMOD inputs are described in Rodrigues et al. (2014); this data was aggregated to lumped scale via weighted-averaging by HRU area. 
Table 3.3 - Parameters of Hymod model

\begin{tabular}{ll}
\hline Parameters & Description \\
\hline $\mathrm{Huz}$ & Maximum height of soil moisture accounting tank $(\mathrm{mm})$ \\
$\mathrm{B}$ & Distribution function shape parameter \\
$\mathrm{Alpha}$ & Quick-slow split parameter \\
$\mathrm{Nq}$ & Number of quickflow routing tanks \\
$\mathrm{Kq}$ & Quickflow routing tanks rate parameter \\
$\mathrm{Ks}$ & Slowflow routing tanks rate parameter \\
\hline
\end{tabular}

The HYMOD model was calibrated to basin outlet streamflow using a multiplecriteria Sub-Period calibration approach, in which the model performance was tested on a number of different periods, so that the selected parameter sets are consistent across individual sub-periods (Gharari et al., 2013).

\subsubsection{Analysis of hydrological models performance}

Both hydrological models were used to simulate the basin response for the 15-year period 1987 to 2001, using the previous year (1986) for model warm up (initialization of model state variables). The calibration period was selected as being the most undisturbed possible condition (Van Loon and Van Lanen, 2013) using observed time series from Jan 1st 1987 (Julian day 1) to Dec 31st 1995 (Julian day 365) and without including any water abstractions. Model performance was then evaluated for the 6-year period Jan 1st 1996 (Julian day 1) to Dec 31st 2001 (Julian day 365). Progressive parameter adjustments were made to achieve the performance criteria thresholds recommended by Moriasi et al. (2007); i.e., NashSutcliffe Efficiency coefficient (NSE) $>0.5$; Percent Bias statistic (PBIAS) $< \pm 25$; coefficient of determination $\left(\mathrm{R}^{2}\right)>0.5$, in addition to seeking a minimum value for Mean Squared Error (MSE) and its components (Appendix A, Eq. A1) (Gupta et al., 2009).

Figure 3.3 shows performance evaluation measures for the one-component hydrograph analysis in which the model-simulated and observed streamflow amounts are compared. The simulation performance achieved by the two models is typical of that reported in the literature. However, whereas the two models achieve similar values for R2, NSE and adjusted linear correlation coefficient, the SWAT model generally has a smaller percent bias.

Considering that the uncertainty in model simulation can be larger during the flood season than during the dry season (Zhang et al., 2014), a two-component hydrograph analysis was conducted in which the streamflow is partitioned into quick (runoff) and slow flow (baseflow) fractions, using the "local-minimum method" filtering methodology (USGS HYSEP program, Sloto and Crouse 1996). The baseflow component is associated with 
groundwater discharge that enters the stream, and is defined as water that sustains flow in a river during low-flow time-periods (Miller et al., 2014), while the runoff time series is defined as the component that flows above the soil surface during and/or shortly after events (Hugenschmidt et al., 2014). Observed and simulated time series of each hydrograph component (baseflow and runoff) were generated, then compared as showed by correlation graphs at the bottom of Figure 3.3. As might be expected, baseflow simulations provided by both models are generally better than the runoff simulations.

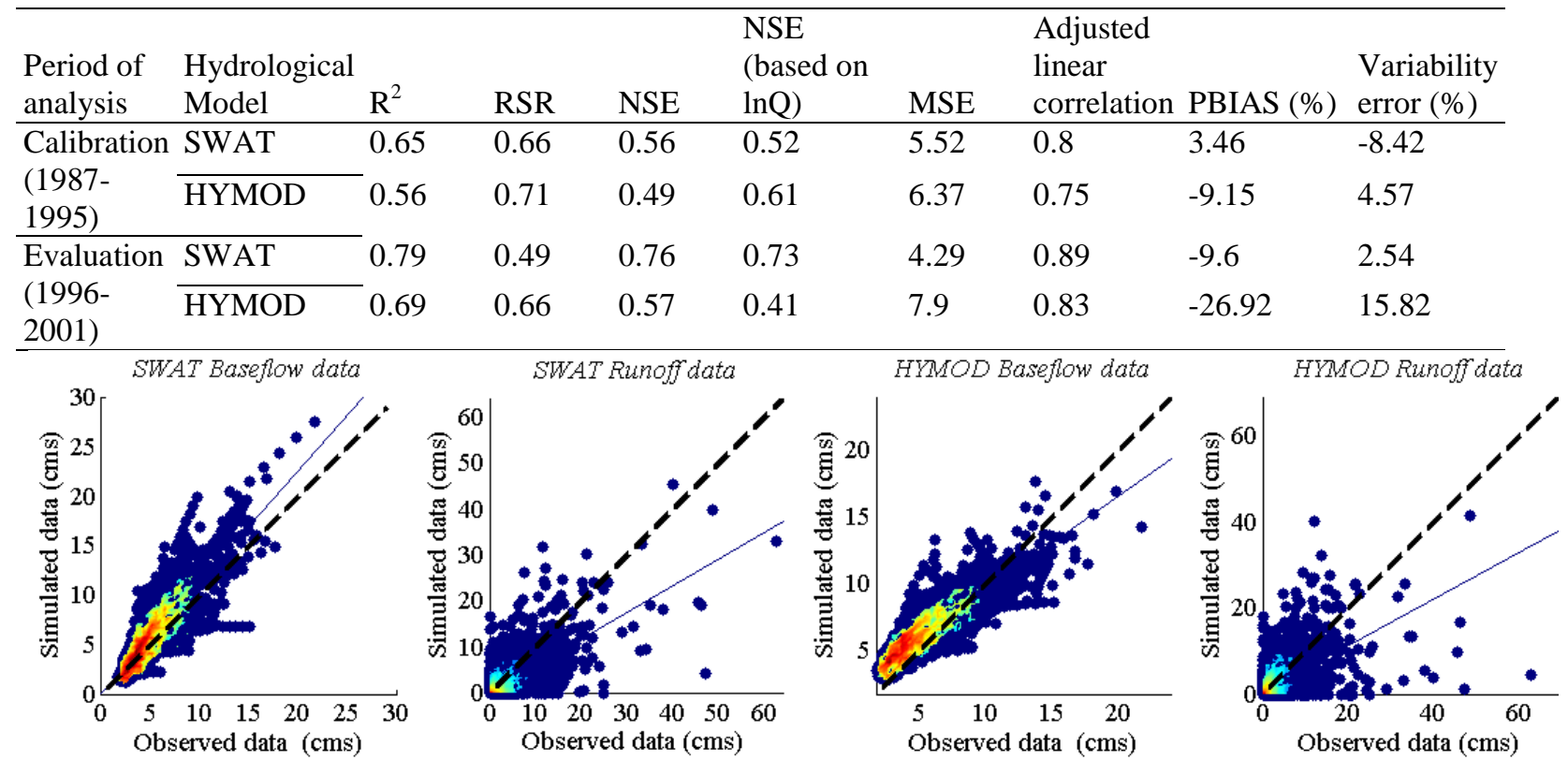

Figure 3.3 - Statistics for model performance with regards to daily streamflow (above) and scatterplot graphs for the calibration and evaluation periods (below)

\subsection{Uncertainties in Streamflow Observed data and Hydrological Modeling}

\subsubsection{Estimation of uncertainty boundaries of measured data}

In examining the residuals of the hydrological models, we take into consideration the random errors resulting from the streamflow measurement process, derived from direct discharge measurements and information regarding construction of the rating-curve (that converts water levels to discharge rates). The uncertainty review provided by Harmel et al. (2006) was used to infer the uncertainty of streamflow measures associated with two sources: the 'velocity-area method' for direct discharge measurements (Sauer and Meyer, 1992); and the 'stage-discharge relationship' (or rating curve) for considering shifting channel beds, both of which are approximately $\pm 20 \%$ (for poor conditions). 
These potential sources of error in the streamflow data were combined to produce a more realistic estimate of the overall error (Harmel et al., 2006). Taking into account that these errors sources are independent (no covariance between them), typically bi-directional, and non-additive, we used the method of moments, derived from a first order approximation of the Taylor series expansion described by the equation (Refsgaard et al., 2007) (Eq. 5).

$E p=\sqrt{\sum_{i=1}^{n}\left(E_{1}^{2}+E_{2}^{2}+E_{3}^{2}+\cdots+E_{n}^{2}\right)}$

where Ep is the probable range in error; $\mathrm{n}$ is the total number of potential errors; $\mathrm{E} 1$ to En are the different potential sources of error.

The results of the error propagation (Ep) analysis were used to define the lower and upper uncertainty bounds on the streamflow measurements (LowerObs and UpperObs) (Eqs. 6 and 7). Then, these measurement data uncertainty boundaries (probable error ranges) were incorporated into a more accurate evaluation of model residuals, as suggested by Harmel and Smith (2007) (see section 2.3.2).

$$
\begin{aligned}
& \operatorname{LowerObs}_{(t)}=O \operatorname{Obs}(t)(1-E p) \\
& \operatorname{UpperObs}_{(t)}=O b s(t)(1+E p)
\end{aligned}
$$

where $\operatorname{Obs}(\mathrm{t})$ is observed data values, the UpperObs(t) is the upper boundary of probable error range of observed data, and LowerObs(t) is the lower boundary of probable error range of observed data.

This probable error ranges of observed values was determined for both streamflow time series (one-component hydrograph), and each of the baseflow and runoff fractions (twocomponent hydrograph). Results for the first case are displayed in Figure 3.4.
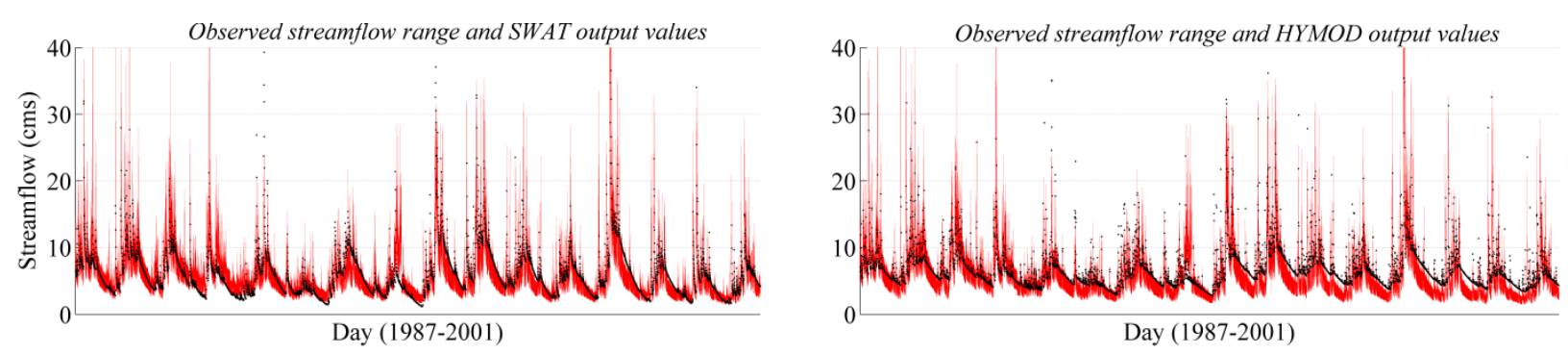

Figure 3.4 - The streamflow output values simulated by the SWAT and HYMOD models (black) overlayed on the probable error range of the observed data (red)

\subsubsection{Estimation of Model Residuals}

In lieu of the traditional method for model residual estimation (where the residual is defined as 'Observed values' minus 'Simulated values') we follow the method of Harmel and 
Smith (2007) which uses the 'probable error ranges' computed from the measured data to conduct a more meaningful evaluation of residuals associated with model inadequacies, as shown by the equations 8 to 10 .

$\varepsilon_{(t)}=0$, if LowerObs $_{(t)} \leq Y_{(t)} \leq \operatorname{UpperObs}_{(t)}$

$\varepsilon_{\text {upper }(t)}=Y_{(t)}-\operatorname{UpperObs}_{(t)}$, if $Y_{(t)}>\operatorname{UpperObs}_{(t)}$

$\varepsilon_{\text {lower }(t)}=Y_{(t)}-\operatorname{LowerObs}_{(t)}$, if $Y_{(t)}<\operatorname{LowerObs}_{(t)}$

where $\varepsilon(\mathrm{t})$ is defined as the model residual for each time step $(\mathrm{t}=1 ; \ldots ; \mathrm{n})$, and $\mathrm{Y}(\mathrm{t})$ is the value simulated by the model.

For each methodological arrangement employed, we estimate the streamflow residuals (using one-component hydrograph analysis) or baseflow and runoff residuals (using twocomponent hydrograph analysis). Then, the upper and lower boundary, model residuals cupper(t) and elower(t), are converted to relative values using Equations 11 and 12, and then converted to positive values (centered on 1.0) by adding one unit as shown in Equations 13 and 14 .

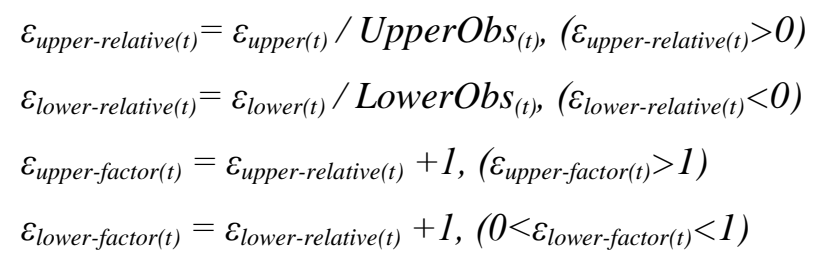

\subsubsection{Bootstrap of Hydrograph Residuals}

Next, the uncertainties associated with simulated streamflow are estimated by bootstrapping the model residuals. Assuming the residuals to be independent and identically distributed (or at least exchangeable) (Chernick, 2008), an empirical residual uncertainty distribution is generated at each time step as follows:

i) Create a new residual series, $\varepsilon^{*}(\mathrm{t})$, by bootstrapping - by randomly resampling $\mathrm{N}$ times with replacement from the aforementioned original set of model residuals, $\varepsilon(\mathrm{t})$, (we use $\mathrm{N}=1000$ );

ii) Create $\mathrm{N}$ synthetic streamflow time series, $\mathrm{Y}^{*}(\mathrm{t})$, by multiplying the new residual series, $\varepsilon^{*}(\mathrm{t})$, to the original model streamflow simulation, $\mathrm{Y}(\mathrm{t})$;

iii) Use the $\mathrm{N}$ synthetic time series, $\mathrm{Y}^{*}(\mathrm{t})$ to define the empirical probability distribution at each time step of the simulated streamflow series.

These steps are repeated separately for the model residuals obtained from the one- and two-component hydrographs, by employing two different bootstrap methods -- Model-based $(\mathrm{MB})$ and Block (BB). In the latter case, the block sizes are estimated using the methodology 
of Politis and White (2004) (as improved by Patton et al. (2009)) that returns an estimate of the optimal stationary block size.

Having generated the $\mathrm{N}$ synthetic streamflow time series, the empirical probability distributions at each time step are used to estimate the $95 \%$ confidence intervals of simulated streamflow using the percentile method. The 1- $\alpha(95 \%)$ confidence interval is defined by the $\alpha / 2$ (2.5th) and 1- $\alpha / 2$ (97.5th) percentiles of the bootstrap distribution of a statistic (Zucchini and Adamson, 1989; Efron and Tibshirani, 1993).

We analyze the overlapping estimates (in terms of percentage area and occurrence period) of the uncertainty bounds on the observed and simulated streamflow time series, where the latter are obtained by combining the uncertainties associated with the two hydrological models, use of one- or two-component hydrographs for residual analysis, and bootstrap methods (Block and Model-Based). The variability of simulated streamflow ranges is evaluated via quantification of water volume covered by their uncertainty bounds.

\subsection{Uncertainty propagation through Water Security indicators}

Using the ensemble of $\mathrm{N}$ synthetic time series generated as above, we next estimate the uncertainty distributions of the scarcity and vulnerability surface water security indicators presented in Section 2.1 (see also Rodrigues et al. (2014)). From these distributions, the 95\% confidence interval uncertainty bounds of the water security indicators are computed using the percentile method, and then combined using weighted-average aggregation for each of the combinations of bootstrap method (Model Based and Block) and hydrograph analysis (one- or two-component). The weights are computed to be proportional to model performance as measured by their adjusted correlation coefficients (Appendix A, Eq. A2) computed for the combined calibration/evaluation period (1987-2001) (SWAT, radj =0.84; and HYMOD, radj $=0.78)$, as suggested by Wilby and Harris (2006).

\section{Results and Discussion}

We first examine the overlap of uncertainty boundaries computed for the observed and simulated streamflow time series (Figure 3.5). Note that each estimate (in terms of area percentage or occurrence period) represents a different combination of bootstrap method 
(Block or Model-Based), hydrological model (SWAT or HYMOD), and use of one- or twocomponent hydrographs for residual analysis.

Of the two bootstrap methods, the Block Bootstrap (BB) method provided a narrower 95\% Confidence Interval (95\% CI) for the simulated time series, as indicated by water volume contained within its bounds (Figure 3.5). The combination of BB method and the twocomponent hydrograph residual analysis generated more accurate results (3rd column, Figure 3.5) than the use of $\mathrm{BB}$ and the one-component hydrograph (1st column, Figure 3.5), as shown by the overlapping values between observed and simulated uncertainties.

The observed-to-simulated overlap and the width of the $95 \% \mathrm{CI}$ is also sensitive to structural differences in the hydrological models. In all of the combinations studied, the uncertainty ranges (indicated by the water volume) of the SWAT model simulation were narrower than the ones obtained using the HYMOD model, consistent with the fact that SWAT is a more physically/conceptually realistic model. However, despite the relative simplicity of HYMOD its performance is surprisingly similar to SWAT (see also Figure 3.3), and in all cases HYMOD provided higher values of the overlap area between observations and simulations, while SWAT obtained higher frequency of such coincidence in most of the cases (Figure 3.5).
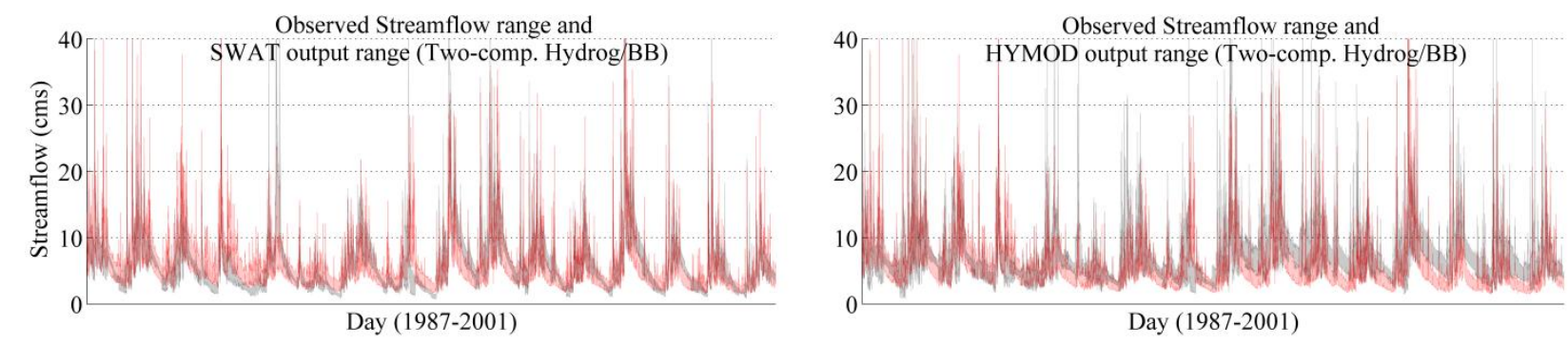

\begin{tabular}{|c|c|c|c|c|}
\hline Methodological arrangement & $\begin{array}{l}\text { One-comp. } \\
\text { hydrograph/ } \\
\text { Block Bootstrap }\end{array}$ & $\begin{array}{l}\text { One-comp. } \\
\text { hydrograph/ } \\
\text { Model-Based } \\
\text { Bootstrap }\end{array}$ & $\begin{array}{l}\text { Two-comp. } \\
\text { hydrograph/ } \\
\text { Block Bootstrap }\end{array}$ & $\begin{array}{l}\text { Two-comp. } \\
\text { hydrograph/ } \\
\text { Model-Based } \\
\text { Bootstrap }\end{array}$ \\
\hline $\begin{array}{l}\text { HYMOD model } \\
\text { Overlapping area (occurrence } \\
\text { period) } \\
\text { (Volume within } 95 \% \text { Conf. Interv.) }\end{array}$ & $\begin{array}{l}28 \%(60 \%) \\
\left(\sim 1.5 \mathrm{~km}^{3}\right)\end{array}$ & $\begin{array}{l}72 \%(79 \%) \\
\left(\sim 3.4 \mathrm{~km}^{3}\right)\end{array}$ & $\begin{array}{l}55 \%(82 \%) \\
\left(\sim 2.5 \mathrm{~km}^{3}\right)\end{array}$ & $\begin{array}{l}71 \%(97 \%) \\
\left(\sim 2.9 \mathrm{~km}^{3}\right)\end{array}$ \\
\hline $\begin{array}{l}\text { SWAT model } \\
\text { Overlapping area (occurrence } \\
\text { period) } \\
\text { (Volume within } 95 \% \text { Conf. Interv.) }\end{array}$ & $\begin{array}{l}27 \%(74 \%) \\
\left(\sim 1.1 \mathrm{~km}^{3}\right)\end{array}$ & $\begin{array}{l}55 \%(94 \%) \\
\left(\sim 1.5 \mathrm{~km}^{3}\right)\end{array}$ & $\begin{array}{l}51 \%(88 \%) \\
\left(\sim 1.8 \mathrm{~km}^{3}\right)\end{array}$ & $\begin{array}{l}68 \%(96 \%) \\
\left(\sim 2.0 \mathrm{~km}^{3}\right)\end{array}$ \\
\hline
\end{tabular}

Figure 3.5 - Uncertainty bounds of observed (red) and simulated (grey) streamflow time series during the calibration and evaluation periods (1987-2001) for a specific methodological arrangement that uses the two-component hydrograph and block bootstrap method (above). Overlapping values, in terms of area and period of time, between both time series ranges and water volume within simulated streamflow range (95\% confidence interval) according to each methodological arrangement analyzed (below) 
The cases involving the BB method used different block sizes of resampling residuals for the one- or two-component hydrograph methods (Table 3.4). Notably, for both hydrological models, the block size of the streamflow residuals (used in the one-compoment hydrograph method) was very similar to that of the baseflow residuals, and was significantly larger than the block size of the runoff residuals (used in the two-component hydrograph method). This can be explained by the large contribution of baseflow to streamflow and the high sensitivity of runoff to occurence of rain events.

Table 3.4 - Block lengths used in methodological arrangements involving block bootstrap

\begin{tabular}{lll}
\hline Methodological arrangement & $\begin{array}{l}\text { One-compoment hydrograph/ } \\
\text { Block Bootstrap }\end{array}$ & $\begin{array}{l}\text { Two-component hydrograph/ } \\
\text { Block Bootstrap }\end{array}$ \\
\hline HYMOD model & 166 days & $\begin{array}{l}\text { Baseflow: 166 days; Runoff: } 44 \\
\text { days }\end{array}$ \\
SWAT model & 141 days & $\begin{array}{l}\text { Baseflow: 148 days; Runoff:44 } \\
\text { days }\end{array}$ \\
\hline
\end{tabular}

To assess the uncertainties of hydrological model parameters, Selle and Hannah (2010) investigated two different block lengths ( 3 and 24 months) to perform a model residual bootstrap analysis, and found remarkably similar uncertainty parameters ranges (95\% CI) for both the MB and BB methods. In contrast, Zhang et al. (2014), who used a different model, found narrower parameter uncertainty boundaries (95\% CI) for the 3-month BB compared to the MB. In our work, the BB method resulted in narrower ranges for the $95 \%$ CIs of EFR methods, water scarcity and vulnerability indicators (Figures 3.6 and 3.7). 

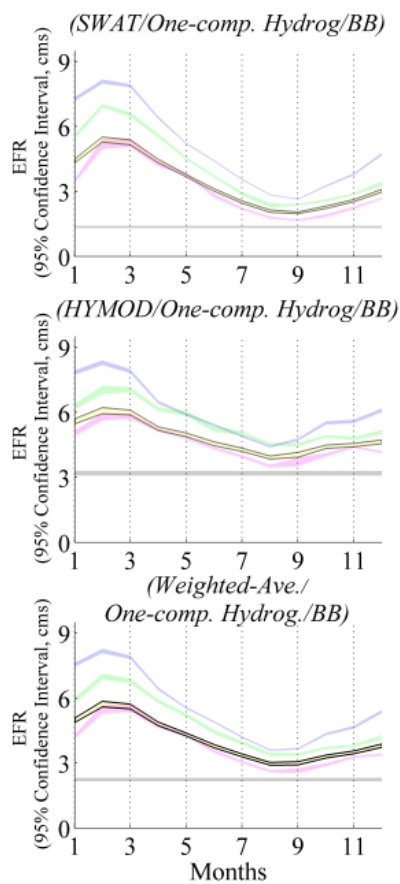
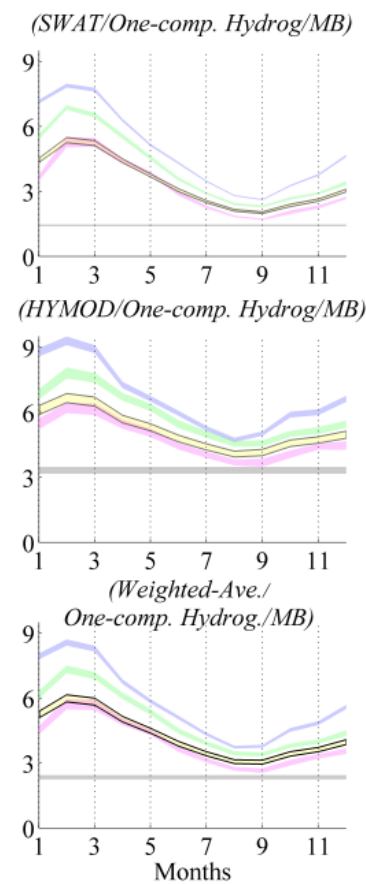

(SWAT/Two-comp. Hydrog/BB)

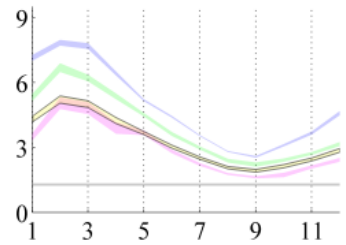

(HYMOD/Two-comp. Hydrog/BB) 9

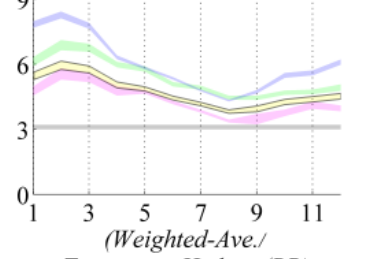

Two-comp. Hydrog./BB)

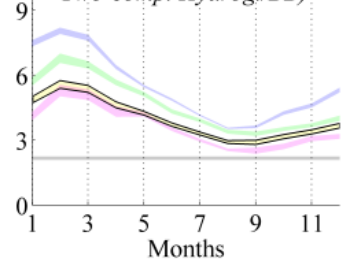

(SWAT/Two-comp. Hydrog/MB)

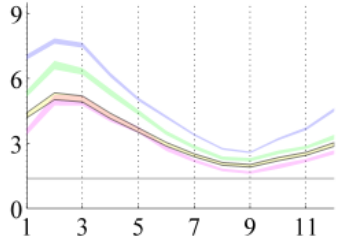

(HYMOD/Two-comp. Hydrog/MB) 9

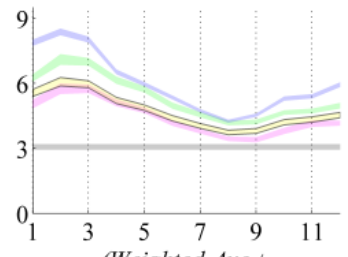

(Weighted-Ave./
Two-comp. Hydrog./MB)

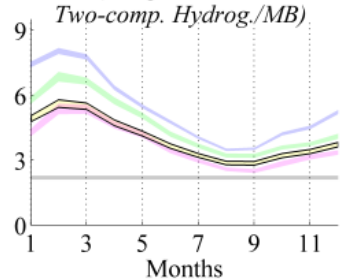

Figure 3.6 - Confidence intervals of Environmental Flow Requirements in accordance with two hydrological models and different methodological arrangements to estimate the uncertainty boundaries. Legend: $\mathrm{EFR}_{\text {presumptive }}$ (blue), $\mathrm{EFR}_{\text {fair }}$ (pink), $\mathrm{EFR}_{\text {moderate }}$ (green), $Q_{7,10}$ (grey)

The number of hydrograph components (one or two) used in residual analysis had no significant impact on EFR and the water security indicators values. However, the results were greatly influenced by the choice of hydrological model. The HYMOD model provided larger and more variable values for EFR, and consequently for the corresponding water use estimates (based on 50\% of Q7,10, Figure 3.6) and water provision levels (calculated from EFR estimates, Eq. 1), thereby affecting the scarcity and vulnerability results (Figure 3.7).

Similar to the temporal pattern obtained by Rodrigues et al. (2014) when conducting a deterministic estimation of water security indicators, the weighted-average water scarcity indicator resulted in higher values predominantly during September, while the vulnerability estimates were highest (range 0.75 to 1 ) during September to November.

In general, the weighted-averages of the water security indicators produced values close to estimates using the EFRfair method (that uses monthly Q90\% seeking fair conservation goals for a considerably modified basin with socio-economic development). Considering that the analysis of EFR methods involves a range of environmental conservation goals, our results indicate the EFRfair method to be the most robust alternative for basin decision-making. 

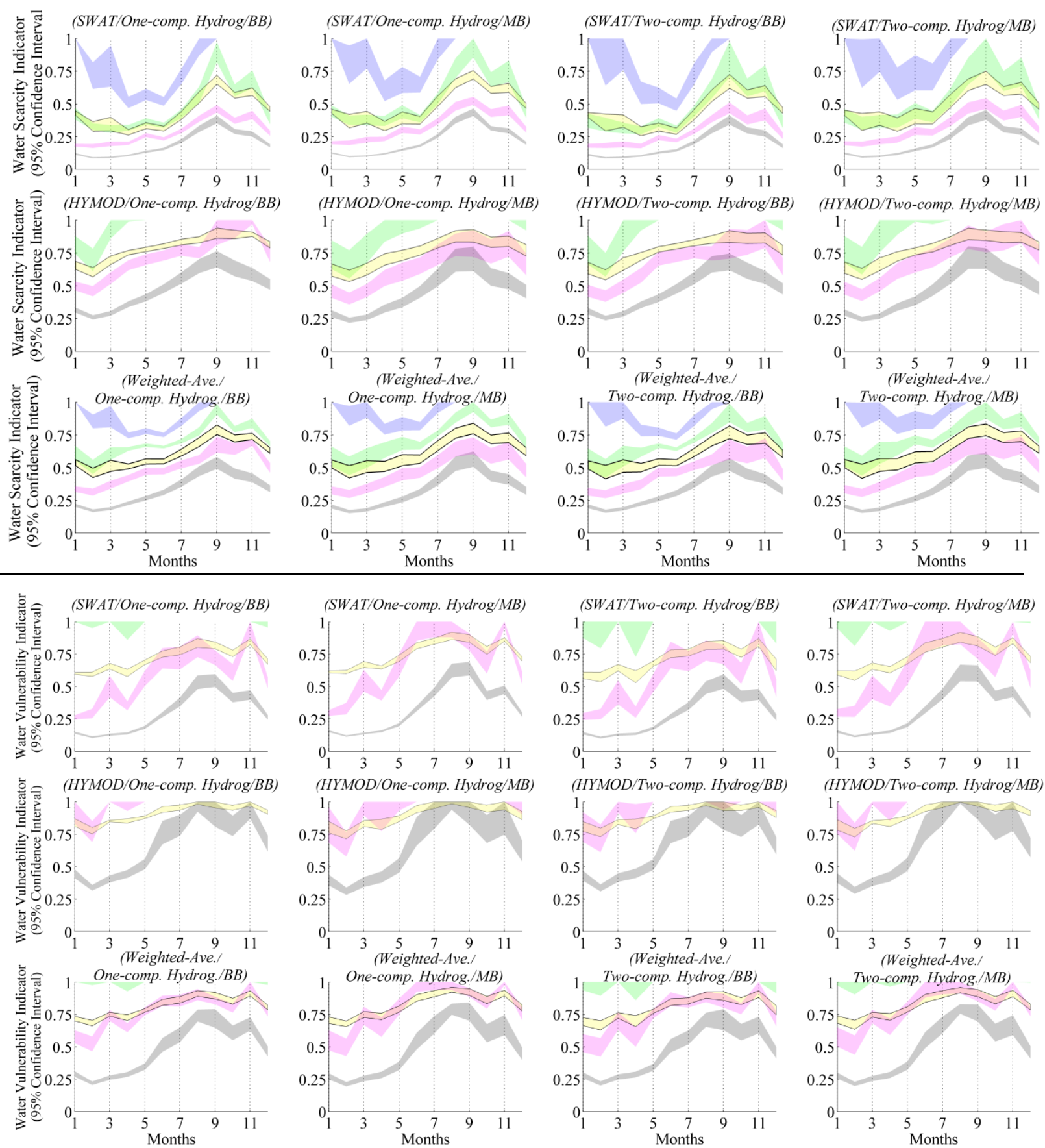

Figure 3.7 - Confidence intervals of Water Scarcity (above) and Vulnerability (below) indicators in accordance with methodological arrangements. Legend: indicator results using $\mathrm{EFR}_{\text {presumptive }}$ (blue color), $\mathrm{EFR}_{\text {fair }}$ (pink), $\mathrm{EFR}_{\text {moderate }}$ (green), $\mathrm{Q}_{7,10}$ (grey), average indicator range (yellow). 


\section{Discussion \& Conclusions}

Science-based advice to decision makers must incorporate information regarding uncertainty about the results (Prudhomme and Davies, 2009). Madani et al. (2014) comment that responsible and comprehensive decision making analysis must inform the stakeholders about the effects of the involved uncertainties on the selected decision and its risk of failure. The integrative framework proposed here has addressed some of the uncertainties discussed by Rodrigues et al. (2014) providing a relatively simple and operationally practical approach to assessing the imprecision in water security indicators caused by uncertainties in and among the models/methods used for such estimation. Consequently, the approach provides a range of probable values (associated with a chosen degree of confidence), instead of deterministic values, for the decision variables of interest.

Yevjevich (1972) emphasizes that since there are no pure deterministic hydrologic processes in nature, hydrological behavior cannot be fully understood and properly applied without the extensive and combined use of stochastic methods of analysis. The decision regarding whether stochastic or deterministic processes dominate is largely a matter of specifying the time horizon and scale of the prediction (e.g. long horizons of prediction are inevitably associated with high uncertainty) (Koutsoyiannis, 2010). The outcomes from an uncertainty analysis are stochastic, but clearly depend on the assumptions made about the nature of the uncertainties and their interactions (Shaw et al., 2010).

We present here a probabilistic framework for assessing the uncertainties in estimates of water security indicators caused by uncertainties in data, methods and models, and expert judgments. The framework is based on a multi-model approach that is able to evaluate model uncertainty and generate ensemble predictions via consideration of multiple plausible models (Mattot et al., 2009), and a resampling-based uncertainty analysis (Mattot et al., 2009) that propagates the uncertainty represented by the model residuals into assessments of water security indicators. The subjective choice of an EFR method depends on how the equilibrium levels for specific situations are selected, taking into account river uses by the local population and the river conditions considered acceptable by them (O'Keefe et al., 2009). Similarly, decisions regarding hydrological modeling depend on hydrological judgment, considering aspects of model adequacy and data availability. Of the methods investigated here, the two-component 
hydrograph residual analysis and Block Bootstrap method generated more accurate and precise uncertainty ranges ( $95 \%$ confidence interval) around the model-simulated time series.

In the context of management for water security, it is important to recognize that there are generally a large number of uncertainty sources that can be considered, including those related to various aspects of the interactions between societal needs, ecosystem functioning, and hydrological conditions. As a practical matter, and given limitations of time, budget, and technical capabilities, it is important that an uncertainty method be suitable for practical application (Gregory et al., 2012). This study has provided a relatively simple approach by which the work of Rodrigues et al. (2014), which provides deterministic estimates of water security indicators, can be extended to obtain an assessment of the imprecision in such indicators due to uncertainties in and among the models/methods used.

This approach can be readily incorporated into a 'Robust Decision Making' approach, that considers many plausible uncertainties, including those due to uncertain model inputs and parameters, alternative views of the future, and hypotheses regarding system structure (Lempert et al., 2006). While uncertainties associated with projecting impacts of climate change on runoff are increasingly well recognized, the difficulties involved in translating these uncertainties to water security have received much less attention (Paton et al., 2013). Our approach can be easily extended to explore the effects of future aspects and other multi-model/resampling techniques, such as: i) stationary and non-stationary climate and ii) water demand scenarios; iii) multiple climate data sources (e.g. Bressiani et al., 2013, in press), iv) natural variability of precipitation data (e.g. Prudhomme and Davies, 2009); and v) use of complementary techniques of hydrograph separation (e.g. Cartwright et al. (2014)). Being both general and practically applicable, the approach can therefore form the basis for meaningful support to end-users facing water resource challenges by enabling them to incorporate a viable uncertainty analysis into a robust decision making process.

\section{Appendix A}

$\mathrm{MSE}=2 \cdot \sigma s \cdot \sigma o \cdot(1-r)+(\sigma s-\sigma o)^{2}+(\mu s-\mu o)^{2}$

where $\sigma \mathrm{s}, \sigma \mathrm{o}=$ standard deviation of the simulated and observed values; $\mu \mathrm{s}, \mu \mathrm{o}=$ mean of the simulated and observed values; $r$ = linear correlation coefficient 
$r_{a d j}=\sqrt{1-\frac{\left(1-r^{2}\right)(N-1)}{N-2}}$

where $\mathrm{N}=$ sample elements

\section{Acknowledgements}

The authors are grateful to research laboratory (NIBH-USP, Brazil) colleagues for help and advice on programming issues, and to São Paulo Research Foundation (FAPESP, grant numbers 2011/11653-0, 2012/05515-6, and 2008/58161-1) and National Counsel of Technological and Scientific Development (CNPq) for supporting the study. The second author obtained partial support from the EU funded SWAN project (grant 294947) under the EU 7th Framework Programme, and from the Australian Research Council through the Centre of Excellence for Climate System Science (grant number CE110001028). The readers can freely access the data used to produce the results of this paper by contacting the corresponding author.

\section{References}

Arnold, J. G., Srinivasan, R., Muttiah, R. S., \& Williams, J. R. (1998). Large Area Hydrologic Modeling and Assessment Part I: Model Development1. JAWRA Journal of the American Water Resources Association, 34(1), 73-89. doi:10.1111/j.1752-1688.1998.tb05961.x

Bastola, S., \& Misra, V. (2014). Evaluation of dynamically downscaled reanalysis precipitation data for hydrological application. Hydrological Processes, 28(4), 19892002. doi:10.1002/hyp.9734

Bressiani, D. A., Srinivasan, R., Jones, C. A., \& Mendiondo, E. M. (in press). Effects of different spatial and temporal weather data resolutions on the streamflow modeling of a semi-arid basin, Northeast Brazil. International Journal of Agricultural and Biological Engineering.

Bressiani, D. A.; Srinivasan, R.; Jones, C. A.; Rodrigues, D. B. B.; Pimentel, I. M. C.; Mendiondo, E. M. (2013), Effects of different spatial and temporal weather data resolutions on streamflow modeling of a semi-arid basin, Northeast Brazil. In: 2013 International SWAT Conference, 2013, Toulouse, France. 2013 International SWAT Conference - Book of Abstracts.

Butts, M. B., J. T. Payne, M. Kristensen, and H. Madsen (2004), An evaluation of the impact of model structure on hydrological modelling uncertainty for streamflow simulation, Journal of Hydrology, 298(1-4), 242-266, doi:10.1016/j.jhydrol.2004.03.042. 
Cartwright, I., B. Gilfedder, and H. Hofmann (2014), Contrasts between estimates of baseflow help discern multiple sources of water contributing to rivers, Hydrol. Earth Syst. Sci., 18(1), 15-30, doi:10.5194/hess-18-15-2014.

Chen, H., Yang, D., Hong, Y., Gourley, J. J., \& Zhang, Y. (2013). Hydrological data assimilation with the Ensemble Square-Root-Filter: Use of streamflow observations to update model states for real-time flash flood forecasting. Advances in Water Resources, 59, 209-220. doi:10.1016/j.advwatres.2013.06.010

Chernick, M. R. (2008). Bootstrap methods: a guide for practitioners and researchers. 2nd ed. Hoboken, New Jersey: John Wiley \& Sons Wiley.

Clark, M. P., Kavetski, D., \& Fenicia, F. (2011). Pursuing the method of multiple working hypotheses for hydrological modeling. Water Resources Research, 47(9), W09301. doi:10.1029/2010WR009827

DeGasperi, C., \& Burkey, J. (2012), Hydrograph Separation using HYDSEP - Matlab code. (Available at www.mathworks.com/matlabcentral/fileexchange/file_infos/36387hydrograph-separation-using-hydsep, accessed 19 June 2014).

Ebtehaj, M., Moradkhani, H., \& Gupta, H. V. (2010). Improving robustness of hydrologic parameter estimation by the use of moving block bootstrap resampling. Water Resources Research, 46(7), W07515. doi:10.1029/2009WR007981

Efron, B. (1979). Bootstrap Methods: Another Look at the Jackknife. The Annals of Statistics, $7(1), 1-26$.

Efron, B., \& Tibshirani, R. J. (1993). An introduction to the bootstrap. Monographs on statistics and applied probability (Vol. 57). CRC Press.

Gassman, P., Reyes, M., Green, C., \& Arnold, J. (2007). The soil and water assessment tool: historical development, applications, and future research directions. Transactions of the $A S A B E$, 50(4), 1211-1250.

Gharari, S., Hrachowitz, M., Fenicia, F., \& Savenije, H. H. G. (2013). An approach to identify time consistent model parameters: sub-period calibration. Hydrol. Earth Syst. Sci., 17(1), 149-161. doi:10.5194/hess-17-149-2013

Gong, W., Gupta, H. V., Yang, D., Sricharan, K., \& Hero, A. O. (2013). Estimating epistemic and aleatory uncertainties during hydrologic modeling: An information theoretic approach. Water Resources Research, 49(4), 2253-2273. doi:10.1002/wrcr.20161

Gregory, R., Failing, L., Harstone, M., Long, G., McDaniels, T., \& Ohlson, D. (2012). Structured Decision Making: A Practical Guide to Environmental Management Choices. John Wiley \& Sons.

Gupta, H. V., Kling, H., Yilmaz, K. K., \& Martinez, G. F. (2009). Decomposition of the mean squared error and NSE performance criteria: Implications for improving hydrological modelling. Journal of Hydrology, 377(1-2), 80-91. doi:10.1016/j.jhydrol.2009.08.003

Harmel, R. D., \& Smith, P. K. (2007). Consideration of measurement uncertainty in the evaluation of goodness-of-fit in hydrologic and water quality modeling. Journal of Hydrology, 337(3-4), 326-336. doi:10.1016/j.jhydrol.2007.01.043

Harmel, R. D., Cooper, R. J., Slade, R. M., Haney, R. L., \& Arnold, J. G. (2006). Cumulative uncertainty in measured streamflow and water quality data for small watersheds. Transactions-American Society of Agricultural Engineers, 49(3), 689. 
Hoekstra, A. Y., A. K. Chapagain, M. M. Aldaya, And M. M. Mekonnen, (2011), The water footprint assessment manual: Setting the global standard, Earthscan, London.

Hu, Y.-M., Liang, Z.-M., Li, B.-Q., \& Yu, Z.-B. (2013). Uncertainty Assessment of Hydrological Frequency Analysis Using Bootstrap Method. Mathematical Problems in Engineering, 2013. doi:10.1155/2013/724632

Hugenschmidt, C., J. Ingwersen, W. Sangchan, Y. Sukvanachaikul, A. Duffner, S. Uhlenbrook, and T. Streck (2014), A three-component hydrograph separation based on geochemical tracers in a tropical mountainous headwater catchment in northern Thailand, Hydrol. Earth Syst. Sci., 18(2), 525-537, doi:10.5194/hess-18-525-2014.

Koutsoyiannis, D. (2010), HESS Opinions "A random walk on water," Hydrol. Earth Syst. Sci., 14(3), 585-601, doi:10.5194/hess-14-585-2010.

Lall, U., \& Sharma, A. (1996). A Nearest Neighbor Bootstrap For Resampling Hydrologic Time Series. Water Resources Research, 32(3), 679-693. doi:10.1029/95WR02966

Lempert, R. J., Groves, D. G., Popper, S. W., \& Bankes, S. C. (2006). A General, Analytic Method for Generating Robust Strategies and Narrative Scenarios. Management Science, 52(4), 514-528. doi:10.1287/mnsc. 1050.0472

Li, Z., Shao, Q., Xu, Z., \& Cai, X. (2010). Analysis of parameter uncertainty in semidistributed hydrological models using bootstrap method: A case study of SWAT model applied to Yingluoxia watershed in northwest China. Journal of Hydrology, 385(1-4), 7683. doi:10.1016/j.jhydrol.2010.01.025

Liu, Y., \& Gupta, H. V. (2007). Uncertainty in hydrologic modeling: Toward an integrated data assimilation framework. Water Resources Research, 43(7), n/a-n/a. doi:10.1029/2006WR005756

Lopez, A., F. Fung, M. New, G. Watts, A. Weston, and R. L. Wilby (2009), From climate model ensembles to climate change impacts and adaptation: A case study of water resource management in the southwest of England, Water Resour. Res., 45(8), W08419, doi:10.1029/2008WR007499.

Madani, K., Read, L., \& Shalikarian, L. (2014). Voting Under Uncertainty: A Stochastic Framework for Analyzing Group Decision Making Problems. Water Resources Management, 28(7), 1839-1856. doi:10.1007/s11269-014-0556-8

Malone, B. P., McBratney, A. B., \& Minasny, B. (2011). Empirical estimates of uncertainty for mapping continuous depth functions of soil attributes. Geoderma, 160(3-4), 614-626. doi:10.1016/j.geoderma.2010.11.013

Matott, L. S., J. E. Babendreier, and S. T. Purucker (2009), Evaluating uncertainty in integrated environmental models: A review of concepts and tools, Water Resources Research, 45(6), W06421.

Matrosov, E. S., Padula, S., \& Harou, J. J. (2013). Selecting Portfolios of Water Supply and Demand Management Strategies Under Uncertainty - Contrasting Economic Optimisation and "Robust Decision Making" Approaches. Water Resources Management, 27(4), 1123 1148. doi:10.1007/s11269-012-0118-x

Miller, M. P., D. D. Susong, C. L. Shope, V. M. Heilweil, and B. J. Stolp (2014), Continuous estimation of baseflow in snowmelt-dominated streams and rivers in the Upper Colorado River Basin: A chemical hydrograph separation approach, Water Resour. Res., 50(8), 6986-6999, doi:10.1002/2013WR014939. 
Moradkhani, H., Sorooshian, S., Gupta, H. V., \& Houser, P. R. (2005). Dual state-parameter estimation of hydrological models using ensemble Kalman filter. Advances in Water Resources, 28(2), 135-147. doi:10.1016/j.advwatres.2004.09.002

Moriasi, D., Arnold, J., Van Liew, M., Bingner, R., Harmel, R., \& Veith, T. (2007). Model Evaluation Guidelines for Systematic Quantification of Accuracy in Watershed Simulations. Transactions of the ASABE, 50(3), 885-900.

Neitsch, S. L., J. G. Arnold, J. R. Kiniry, and J. R. Williams (2011), SWAT theoretical documentation version 2009, Soil and Water research laboratory. Grassland.

O'Keeffe, J. (2009). Sustaining river ecosystems: balancing use and protection. Progress in Physical Geography, 33(3), 339-357. doi:10.1177/0309133309342645

Padowski, J. C., \& Jawitz, J. W. (2012). Water availability and vulnerability of 225 large cities in the United States. Water Resources Research, 48(12), W12529. doi:10.1029/2012WR012335

Paton, F. L., Maier, H. R., \& Dandy, G. C. (2013). Relative magnitudes of sources of uncertainty in assessing climate change impacts on water supply security for the southern Adelaide water supply system, Water Resources Research, 49(3), 1643-1667, doi:10.1002/wrcr.20153.

Patton, A., Politis, D., \& White, H. (2009). Correction to Automatic Block-Length Selection for the Dependent Bootstrap by D. Politis and H. White. Econometric Reviews, 28(4), $372-375$.

PCJ - Piracicaba, Capivari e Jundiaí rivers basin committee (2011). Plano das bacias hidrográficas dos rios Piracicaba, Capivari e Jundiaí 2010-2020: relatório síntese, Cobrape, São Paulo. (Available at http://www.comitepcj.sp.gov.br/download/PB/PCJ_PB2010-2020_Sintese.pdf, accessed 10 Jan. 2013.).

Politis, D. N., and White, H. (2004). Automatic block-length selection for the dependent bootstrap. Econometric Reviews 23(1):53-70.

Prudhomme, C., \& Davies, H. (2009). Assessing uncertainties in climate change impact analyses on the river flow regimes in the UK. Part 1: baseline climate. Climatic Change, 93(1-2), 177-195. doi:10.1007/s10584-008-9464-3

Refsgaard, J. C., van der Sluijs, J. P., Højberg, A. L., \& Vanrolleghem, P. A. (2007). Uncertainty in the environmental modelling process - A framework and guidance. Environmental Modelling \& Software, 22(11), 1543-1556. doi:10.1016/j.envsoft.2007.02.004

Reilly, C. F., \& Kroll, C. N. (2003). Estimation of 7-day, 10-year low-streamflow statistics using baseflow correlation. Water Resources Research, 39(9), n/a-n/a. doi:10.1029/2002WR001740

Richter, B. D., Davis, M. M., Apse, C., \& Konrad, C. (2012). A Presumptive Standard for Environmental Flow Protection. River Research and Applications, 28(8), 1312-1321. doi:10.1002/rra.1511

Rodrigues, D. B. B., Gupta, H. V., \& Mendiondo, E. M. (2014). A blue/green water-based accounting framework for assessment of water security. Water Resources Research, 50. doi:10.1002/2013WR014274 
Rougier, J., Goldstein, M., \& House, L. (2013). Second-Order Exchangeability Analysis for Multimodel Ensembles. Journal of the American Statistical Association, 108(503), 852863. doi:10.1080/01621459.2013.802963

Sansom, P. G., Stephenson, D. B., Ferro, C. A. T., Zappa, G., \& Shaffrey, L. (2013). Simple Uncertainty Frameworks for Selecting Weighting Schemes and Interpreting Multimodel Ensemble Climate Change Experiments. Journal of Climate, 26(12), 4017-4037. doi:10.1175/JCLI-D-12-00462.1

Sao Paulo State (1994), Law n. 9034. Water Resources State Plan. (Available at http://www.jusbrasil.com.br/legislacao/174303, accessed 01 May 2012)

Sauer, V. B., and R. W. Meyer. 1992. Determination of error in individual discharge measurements. USGS Open File Report 92-144. Washington, D.C.: USGS.

Selle, B., \& Hannah, M. (2010). A bootstrap approach to assess parameter uncertainty in simple catchment models. Environmental Modelling \& Software, 25(8), 919-926. doi:10.1016/j.envsoft.2010.03.005

Shao, Q., Lerat, J., Brink, H., Tomkins, K., Yang, A., Peeters, L., et al. (2012). Gauge based precipitation estimation and associated model and product uncertainties. Journal of Hydrology, 444-445, 100-112. doi:10.1016/j.jhydrol.2012.04.009

Shao, Q., Lerat, J., Podger, G., \& Dutta, D. (2014). Uncertainty estimation with biascorrection for flow series based on rating curve. Journal of Hydrology, 510, 137-152. doi:10.1016/j.jhydrol.2013.12.025

Shaw, E. M., K. J. Beven, N. A. Chappell, and R. Lamb (2010), Hydrology in Practice, 4th ed., CRC Press.

Sloto, R. A., and M. Y. Crouse (1996), HYSEP, a computer program for streamflow hydrograph separation and analysis, Water-resources investigations report; 96-4040, U.S. Dept. of the Interior, U.S. Geological Survey; Branch of Information Services, Lemoyne, Pennsylvania. (Available at https://water.usgs.gov/software/HYSEP/code/doc/hysep.pdf, accessed 19 June 2014)

Smakhtin, V. U., \& Eriyagama, N. (2008). Developing a software package for global desktop assessment of environmental flows. Environmental Modelling \& Software, 23(12), 13961406. doi:10.1016/j.envsoft.2008.04.002

Smakhtin, V., Revenga, C., \& Döll, P. (2004). A pilot global assessment of environmental water requirements and scarcity. Water International, 29(3), 307-317.

Srinivas, V. V., \& Srinivasan, K. (2005). Matched block bootstrap for resampling multiseason hydrologic time series. Hydrological Processes, 19(18), 3659-3682. doi:10.1002/hyp.5849

Sullivan, C. A. (2011). Quantifying water vulnerability: a multi-dimensional approach. Stochastic Environmental Research and Risk Assessment, 25(4), 627-640. doi:10.1007/s00477-010-0426-8

Tasker, G. D. (1987). A Comparison of Methods for Estimating Low Flow Characteristics of Streams1. Journal of the American Water Resources Association, 23(6), 1077-1083. doi:10.1111/j.1752-1688.1987.tb00858.x

Tebaldi, C., \& Knutti, R. (2007). The use of the multi-model ensemble in probabilistic climate projections. Philosophical Transactions of the Royal Society A: Mathematical, Physical and Engineering Sciences, 365(1857), 2053-2075. doi:10.1098/rsta.2007.2076 
Van Loon, A. F., \& Van Lanen, H. a. J. (2013). Making the distinction between water scarcity and drought using an observation-modeling framework. Water Resources Research, 49(3), 1483-1502. doi:10.1002/wrcr.20147

Vogel, R. M., \& Shallcross, A. L. (1996). The moving blocks bootstrap versus parametric time series models. Water Resources Research, 32(6), 1875-1882. doi:10.1029/96WR00928

Vrugt, J. A., Diks, C. G. H., Gupta, H. V., Bouten, W., \& Verstraten, J. M. (2005). Improved treatment of uncertainty in hydrologic modeling: Combining the strengths of global optimization and data assimilation. Water Resources Research, 41(1), W01017. doi:10.1029/2004WR003059

Wagener, T., Boyle, D. P., Lees, M. J., Wheater, H. S., Gupta, H. V., \& Sorooshian, S. (2001). A framework for development and application of hydrological models. Hydrol. Earth Syst. Sci., 5(1), 13-26. doi:10.5194/hess-5-13-2001

Whately, M., and P. Cunha (2007), Cantareira 2006: um olhar sobre o maior manancial de água da Região Metropolitana de São Paulo, Instituto Socioambiental, São Paulo. (Available at http://www.socioambiental.org/banco_imagens/pdfs/10289.pdf, accessed 14 Apr. 2013)

Wilby, R. L., \& Dessai, S. (2010). Robust adaptation to climate change. Weather, 65(7), 180185. doi:10.1002/wea.543

Wilby, R. L., \& Harris, I. (2006). A framework for assessing uncertainties in climate change impacts: Low-flow scenarios for the River Thames, UK. Water Resources Research, 42(2), n/a-n/a. doi:10.1029/2005WR004065

Zhang, Z., Lu, W., Chu, H., Cheng, W., \& Zhao, Y. (2014). Uncertainty analysis of hydrological model parameters based on the bootstrap method: A case study of the SWAT model applied to the Dongliao River Watershed, Jilin Province, Northeastern China. Science China Technological Sciences, 57(1), 219-229. doi:10.1007/s11431-013-5385-0

Zucchini, W., \& Adamson, P. T. (1989). Bootstrap confidence intervals for design storms from exceedance series. Hydrological Sciences Journal, 34(1), 41-48. doi:10.1080/02626668909491307 


\section{GENERAL CONCLUSIONS}

The research steps developed along this doctoral thesis discusses a number of conceptual and accounting aspects to contribute to water security assessment.

In the first chapter, the study indicates that the American system could potentially benefit from some of the principles present in Brazilian framework, including a) participatory approach involving government, users, and citizens, b) recognition of the economic value of water, and c) prioritization of drinking water supply during shortage times. In turn, the Brazilian system could be benefited from certain characteristics of American water management, including reduced bureaucracy and a more efficient decision and operation process. Interestingly, both countries have found it useful to employ soft-path solutions to ensure system adaptability to future water demand and supply, including the use of water bank mechanisms and water rights transfers to supplement physical water transfer operations.

The second chapter, in turn, concludes that the Blue/Green water-based accounting framework proposed here provides a comprehensive and relatively simple integration of hydrologic, ecosystem and human needs information on a monthly basis. It can be benchmarked at a range of climate conditions, spatial scales, land and water uses, which will be useful to water managers by increasing their understanding of how, where and when, and to what level water-related threats to human and aquatic ecosystem security arise. Further investigation is suggested to better understand i) the uncertainties associated with database and methods using a stochastic approach, ii) the effects of climate change projections on blue and green freshwater provision, iii) the expansion of the framework involving other sources of water (groundwater and reservoirs), iv) specific analysis of critical probabilistic water provision levels for vulnerability estimation and severity classification of both scarcity and vulnerability indicators values., and v) the estimates of non-consumptive water use provided by the Grey Water Footprint component (the water needed for the regulating ecosystem services).

The third chapter incorporates an uncertainty analysis based on multi-model and resampling approaches that can provide feasible support to end-users facing water resource challenges and robust decision making process. This stochastic framework is sufficiently general while being practically applicable, and can be extended to explore the effects of future aspects and other multi-model/resampling techniques, such as: i) stationary and non-stationary 
climate and ii) water demand scenarios; iii) multiple climate data sources and iv) natural variability of precipitation data by resampling technique; and v) incorporation of the next steps of 'Robust Decision Making', including robust adaptation measures.

The process of elaboration of the chapters in format of papers promoted great advances in the methodological delineation and discussion aspects, due to the cooperation of co-authors, and constructive criticisms from the high-level journals reviewers. 